\title{
A higher rebound effect under bounded rationality: Interactions between car mobility and electricity generation
}

\author{
Karolina Safarzyńska \\ Faculty of Economic Sciences \\ Warsaw University \\ Dluga 44/50 \\ 00-241 Warsaw, Poland \\ ksafarzynska@wne.uw.edu.pl \\ and \\ Jeroen C.J.M. van den Bergh \\ ICREA, Barcelona \\ and \\ Institute of Environmental Science and Technology \\ Universitat Autònoma de Barcelona, \\ Edifici Z - Campus UAB, 08193 Bellaterra, Spain \\ and
}

Faculty of Economic and Business Administration \& Institute for Environmental Studies,

VU University Amsterdam

jeroen.bergh@uab.es

May, 2018

Published as:

Safarzyńska, K., and J.C.J.M. van den Bergh (2018). A higher rebound effect under bounded rationality: Interactions between car mobility and electricity generation. Energy Economics 74: 179-196. 


\begin{abstract}
It is widely believed that with the right economic incentives, electrification of transport can significantly reduce $\mathrm{CO}_{2}$ emissions by 2050. Estimates of future emissions from car transport tend, though, to ignore technological change in electricity generation and bounded rationality of consumers. In this article we address these two shortcomings by developing a novel approach that captures the dynamic interdependence between the car industry and electricity generation. We assess how incorporating realistic behaviors affects estimates of emissions from passengers cars in four models of vehicle adoption, namely with rational, myopic, habit-oriented and loss-aversive consumers. This is then combined with three behavioral models of travel distance, describing rational, habitual and loss-averse drivers. In the electricity sector, technological change occurs through installation of new power plants embodying different energy technologies. This allows us to study the impact of policies promoting renewable energy on the price of electricity, and indirectly on the rate of adoption of electric cars. The findings indicate that substituting renewable energy for fossil fuels in electricity generation by 2050 can triple the electricity price. This undermines the positive effect of subsidies on electric car adoption, with the specific effect depending on particular behaviors assumed to hold. In addition, we show that myopic and loss-averse consumers buy on average less fuel-efficient cars than rational agents. Habitual drivers tend to commute larger distances than rational ones, as they do not adjust their behavior optimally to changes in fuel prices and improvements in fuel efficiencies. These behavioral effects contribute to the rebound effect. Our findings indicate that vehicle choice and driving under rational behavior generate consistently the lowest estimates of life-cycle emissions. By ignoring more realistic behaviors consistent with bounded rationality, current studies underestimate emissions from passenger cars, in turn contributing to overly optimistic expectations about policy impacts.
\end{abstract}




\section{Introduction}

Addressing climate change requires a radical transformation of the transport system. To illustrate, it is responsible for $25 \%$ of total emissions in the European Union (EPRS, 2015). In this context, the diffusion of electric vehicles is a high priority for policymakers. Electrification of transport is expected to reduce $\mathrm{CO}_{2}$ emissions as it eases gasoline-dependency while it also improves local air quality. However, depending on the location, electric vehicles may be currently more detrimental to the environment than petrol-powered vehicles because of the pollution created in the process of generating electricity (Holland et al., 2016). A recent study shows that even within a specific location, emissions from electric cars vary up to $22 \%$ due to spatial and temporal variations in the temperature, which affects vehicle efficiency and charging duration (Yuksel and Michalek, 2015). Moreover, the emissions from car transport depend on the rate of market penetration of electric and fuel-efficient vehicles, and how consumers adjust their driving behavior to changes in fuel prices. Existing studies adopt a simplified model of rational choice to study future emissions from the transport sector (Michalek et al., 2011; Kasten et al., 2016; Miotti et al., 2016; Holland et al., 2016). This is surprising given a number of behavioral anomalies that have been identified in the literature to affect car choice and driving behavior (Busse et al., 2013; Garcia-Sierra et al., 2015; Gossling and Metzler, 2017).

In this paper, we study how incorporating realistic behaviors about purchase and use of electric and conventional cars affects estimates of their life-cycle emissions. For this purpose, we develop a novel framework that captures the dynamic interdependence between the electricity sector and the car industry. The framework combines four elements: an econometric analysis of fuel economies of new cars in Germany between 2010-2015; a life-cycle analysis of emissions from conventional and electric cars; discrete choice models of vehicle adoption and driving that incorporate realistic behaviors; and a model of the electricity sector. The parameters describing the electricity market are tailored to the data from the German electricity market. We focus on Germany, as it constitutes an interesting case study, because of the country's ambitious climate change and renewable energy targets.

Formally, we study total emissions from car transport in four models of vehicle adoption, namely with rational, myopic, habit-oriented and loss-aversive consumers. This is then combined with three behavioral models of travel distance, namely with rational, habitual and loss-averse drivers. In total, our design gives rise to $4 \times 3=12$ different combination of behavioral models of car choice and driving. This allows us to systematically compare how different types of boundedly-rational behaviors affect emissions

from car transport. We find that the rational model of vehicle choice and driving generates consistently the lowest estimates of future emissions. As a result, if behavioral models are closer to the truth, current models may underestimate future emissions, and generate ineffective policy advice. For instance, we show that myopic and loss-averse consumers on average buy less fuel-efficient cars than rational agents. In turn, 
habitual drivers tend to commute larger distances than rational ones as they do not adjust their behavior promptly to changes in fuel prices and improvements in fuel efficiencies. Finally, we show that the probability of the rebound effect differs substantially between alterative behavioral models of car choice and driving, and discuss policy implication of these findings.

Our paper relates to the burgeoning literature on how the myopia of consumers affects car purchases and driving behavior. In particular, much attention has been devoted to the question of whether consumers undervalue future gasoline prices when they make car purchase decisions (Kilian and Sims, 2006; Sallee et al., 2009; Allcott and Wozny, 2014). Formally, such studies examine how the distribution of cars, characterized by different fuel economies, adjust to variations in gasoline prices (Kahn, 1989; Kilian and Sims, 2006; Salee et al., 2009). For instance, the analysis of car purchasing data indicates that consumers are indifferent between $\$ 1$ in the discounted gasoline cost and $\$ 0.76$ in the vehicle purchase price, which supports that they undervalue future fuel expenses when buying a car (Allcott and Wozny, 2014). In turn, Kilian and Sims (2006) show that not only car prices under-adjust to changes in the price of gasoline, but also that the increases in the price of gasoline have a relatively strong effect on used automobile prices while decreases do not, contrary to the assumptions of the conventional theory based on rational agents.

Other empirical evidence from behavioral studies indicates that people engage in narrow framing of losses and gains (Barberis and Huang, 2001; Kahneman and Lovalo, 1993), which may create an obstacle to adoption of fuel-efficient and electric vehicles. In particular, monthly payments on fuel may be evaluated separately from spending on the price of purchasing a car, influencing consumers' choice of a car's fuel type and its efficiency. To illustrate, many car owners in urban areas would be financially better off by selling their car and using a combination of taxis and rented cars (Thaler, 1999). However, paying a fee to take a taxi is mentally linked to spending on consumption, which consumers prefer to avoid. Instead, monthly cars payments are categorized as a different type of expense. Similarly, consumers may evaluate the cost of purchasing a car against a different budget than future payments on fuel. This would disfavor more expensive cars that generate fuel savings over time, such as electric vehicles.

From another angle, we look at the impact of the diffusion of renewable energy in electricity production on the price of electricity, and subsequently on the rate of adoption of electric vehicles. So far, the impact of technological change in the electricity sector on the rate of adoption of electric vehicles has not achieved much scrutiny so far. To address this question, our model considers the impact of investments in renewable energy on the electricity price. In fact, research has been far from conclusive over short- and long- term impacts of the share of renewable energy in electricity production on the electricity price. Standard economic theory predicts that increasing its share may reduce the price of electricity in the short run, known as the merit-order effect (Jensen and Skytte, 2002). However, in the long run, the diffusion of 
renewable energy has been typically financed by increasing the final electricity price paid by consumers (Moreno et al., 2012). The proposed framework captures these two opposing effects on the electricity price.

We assume that technological change on the electricity market occurs through the installation of power plants embodying different energy technologies, following Safarzynska (2012) and Safarzynska and van den Bergh $(2011,2017)$. Formally, the electricity market is composed of heterogeneous power plants producing electricity from diverse energy sources. Plants, which reached the maximum lifespan, leave the market, and are replaced by new power stations. The size and the fuel type embodied in a newly installed power station is determined by the discounted value of investments in different energy technologies. We find that replacing fossil fuels in electricity generation by renewable energy around 2050 may triple the electricity price, undermining the positive effect of subsidies for the purchase of electric cars on their adoption rate. The intensity of this effect of subsidies depends on the particular behavioral model of car choice employed. The reminder of this paper is organized as follows. In Section 2, we provide an overview of the model and discuss its empirical validation. This is followed by results in Section 3. Finally, Section 4 concludes.

\section{The model and its empirical validation}

The model links car and electricity markets. Section 2.1 studies the rate of adoption of electric and fuelefficient conventional cars in alternative behavioral models. We focus on consumers, who are fully-rational, myopic, loss-averse, and habit following. Formally, we incorporate these distinct behaviors into a discrete choice model. In Section 2.2, we examine how rational, habit-oriented and loss-averse consumers adjust their driving to changes in fuel prices so as to estimate the total emissions from car transport. The demand for electric cars is driven by their price and the cost of electricity, which in turn depends on the dynamics on the electricity market as described in Section 2.3.

\subsection{Behavioral models of car choice}

In the market for cars, $n$ vehicle designs compete for adoption by $m$ consumers. Each period, a number $m$ of new consumers enter the market, to which will refer as a cohort $l$. Vehicle designs differ with respect to fuel type $f(f=$ petrol $(p)$, diesel $(d)$, electric $(e)$, hybrid $(h))$, and their fuel economy $F C_{k t}{ }^{1}$ or electricity efficiency $z w h_{k}(\mathrm{Wh} / \mathrm{km})$. Formally, we consider four discrete behavioral choice models, where consumer $i$ selects the product $k$ which maximizes the behavioral (beh) utility: $U_{i k t}^{\text {beh }}\left(X_{k t}, P_{k t}, \xi_{k}\right)$, with $X_{k t}, P_{k t}$ and $\xi_{k}$ denoting observed product characteristics, vehicle price and unobservable characteristics, respectively.

\footnotetext{
${ }^{1} \mathrm{FC}$ is expressed in terms of $(\mathrm{L} / 100 \mathrm{~km})$ if $f \in\{p, d\}$.
} 
In the first model, we assume that rational consumers choose a car design that maximizes their utility:

$$
U_{i k t}^{\text {rational }}=\beta_{k}+\beta_{1} \ln \left(G_{k t}+P_{k t}\right)+\beta_{2} D_{f}+\xi_{k}+\varepsilon_{i k},
$$

where $G_{k t}$ captures the discounted fuel cost; $D_{f}$ is a dummy equal to 1 for electric and hybrid cars; $\varepsilon_{i k}$ captures unobserved consumer-specific taste parameters; and $\xi_{k}$ can be thought of as the mean of unobserved product characteristics.

The discounted cost of fuel over the vehicle lifetime is calculated as:

$$
G_{k t}=\sum_{t=o}^{T} f c_{k t} * x * p^{e} f t\left(\frac{1}{1+r}\right)^{t}
$$

where $r$ is the discount rate; $T$ is the expected ownership time; $x_{j k t}$ is expected distances commuted annually by each car owner $(\mathrm{km})$; and $f c_{k t}$ captures the unit fuel efficiency, i.e. the amount of fuel (liters) in case of conventional cars, or the number of KWh of electricity, required to drive $1 \mathrm{~km}$.

In equation (2), $p_{f t}^{e}$ captures consumers' expectations regarding the price of fuel $f$ at time $t$, which is approximated by a random walk:

$$
p_{f t+1}^{e}=p_{f t}^{e}+\xi_{f} .
$$

Given empirical evidence that consumers undervalue fuel prices compared to the price of a vehicle (e.g. Allcott and Wozny, 2014), in the second model we assume that consumers are myopic in this sense, and evaluate the discounted fuel cost and the vehicle price separately from one another:

$$
U_{i k t}^{\text {myopic }}=\beta_{k}+\beta_{1} \ln \left(G_{k t}\right)+\beta_{2} \ln \left(P_{k t}\right)+\beta_{3} D_{f}+\xi_{k}+\varepsilon_{i k},
$$

Instead of minimizing the discounted cost of car ownership, consumers may compare alternative car specifications on an attribute-to-attribute basis to other, aiming at minimizing a weighted average of attribute differences between cars (e.g. Rasouli and Timmermans, 2016). Moreover, empirical evidence suggests that consumers are likely to frame differently losses and gains, and prefer avoiding losses to acquiring equivalent gains, which has been referred in the literature as loss aversion (Kahneman and Tversky, 1979). In view of this, in the third model we assume loss-averse consumers who chose a car design based on:

$$
U_{i k t}^{\text {loss-averse }}=\beta_{k}+\beta_{1} \text { pos } G_{k t}+\beta_{2} a b s G_{k t}+\beta_{3} \text { pos } P_{k t}+\beta_{4} a b s P_{k t}+\beta_{5} D_{f}+\xi_{k}+\varepsilon_{i k}
$$

According to equation (5), consumers compare $k$ design with a selected car design $j$. Here, pos $G_{k t}$ captures the difference in the discounted costs between $k$ and $j$ designs if the difference is positive, and $a b s G_{k t}$ captures the absolute value of such a difference, if it is negative. Analogously, pos $P_{k t}$ and $a b s P_{k t}$ measure respectively positive and absolute negative difference in car prices between $k$ and $j$ 's designs. To 
illustrate with an example, if the discounted fuel cost associated with car design $k$ exceeds that of design $j$, then the difference in costs between these designs, $\operatorname{pos} G_{k t}$, will be a source of disutility from buying design $\mathrm{k}$. To reflect the latter $\beta_{2}$ will be negative. On the other hand, if the discounted fuel cost of design $k$ is lower than that of design $j$, the difference in costs will be negative. The absolute value of this difference $a b s G_{k t}$ will be a source of utility, thus $\beta_{1}>0$. The absolute value of $\beta_{2}$ exceeding $\beta_{1}$ will capture risk aversion, indicating that people are more concerned with losses than gains, which we will examine empirically in the next section.

Finally, consumers' purchasing choice and driving behavior often show a sign of inertia. For instance, individuals have a strong predisposition to choose a car, whose attributes are similar to the one which they own currently (Hoen and Geurs, 2011). This can be conceptualized as habit-oriented consumers maximizing the utility:

$$
U_{i k t}^{\text {habitual }}=\beta_{k}+\beta_{1} \ln \left(G_{k t}\right)+\beta_{2} \ln \left(p_{k t}\right)+\beta_{3} D_{f}+\beta_{3} D S_{k t-1}+\varepsilon_{i k}
$$

where consumers' utility depends on whether they purchased a particular model in the past. To capture this, $D S_{k t-1}$ takes value 1 if a consumer bought the $k^{\text {th }}$ design in the past and 0 otherwise.

We consider a sufficiently larger number of consumers, which allows us to approximate market shares of different designs $m_{k t}$ by the probability that a consumers adopts design $k \rho^{\text {beh }}{ }_{i k t}$ :

$$
\rho^{b e h}{ }_{i k t}=m s^{b e h}{ }_{k t}=\frac{\exp *\left(U^{b e h}{ }_{i k t}\right)}{\sum_{j} \exp *\left(U^{b e h}{ }_{i k t}\right)},
$$

where $U^{b e h}$ captures the utility derived by consumers from purchasing design $k$, in different behavioral models $b e h=\{$ rational, myopic, loss-averse, habitual $\}$.

\subsubsection{Empirical validation}

To predict future vehicle adoptions, we estimate parameters in the utility functions (1,4-6) using the EU registration data of newly registered cars between 2010 and 2015 in Germany². According to the EC regulation (no 443/2009), all EU member states are required to record information for each new passenger car registered in its territory, including: manufacturer name, type, variant, version, commercial name, specific emissions of $\mathrm{CO} 2$, mass of the vehicle, fuel type etc. We estimate coefficients in the utility functions using a subset of the registration data, including 341 car designs by 32 manufacturers in Germany, whose sales either exceeded $2 \mathrm{k}$ cars in 2010, or embodied an electric or hybrid engine regardless of the number of such cars sold.

\footnotetext{
${ }^{2}$ Downloaded at http://www.eea.europa.eu/data-and-maps/data/co2-cars-emission-11
} 
As equations $(1,4-6)$ describe utilities of individual consumers, to estimate parameters in the utility functions based on the aggregate registration data, we aggregate discrete choice models of individual consumer behaviors to derive total demand for each car, following Berry's (1994, 1995) methodology. In particular, we estimate parameters in the transformed equations:

$$
\delta_{k t}=\ln \left(m s_{k t}\right)-\ln \left(m s_{j t}\right)=\left(\beta_{k}-\beta_{j}\right)\left(X_{k t}-X_{j t}\right)+\varepsilon_{i k}-\varepsilon_{j 1},
$$

where subscript $j$ corresponds to a selected car design, to which we compare historical market shares ( $m s)$ and characteristics $(X)$ of design $k$. We selected FIAT 500 as a reference model, as its sales in each year where close to the median. Subsequently, for each behavioral model, we estimate parameters in the transformed equations corresponding to utilities in $(1,4-6)$ respectively:

For the rational-agent model:

$$
\ln \left(m s_{k t}\right)-\ln \left(m s_{j t-1}\right)=\beta_{k}-\beta_{j}+\beta_{k}\left(\ln \left(G_{k t}+P_{k t}\right)-\ln \left(G_{j t}+P_{j t}\right)\right)+\beta_{2}\left(D_{f k}-D_{f j}\right)+\varepsilon_{i k}-\varepsilon_{j 1},
$$

For the myopic-agent model, the regression takes a form:

$$
\begin{aligned}
& \ln \left(m s_{k t}\right)-\ln \left(m s_{j t-1}\right)=\beta_{k}-\beta_{j}+\beta_{1}\left(\ln \left(G_{k t}\right)-\ln \left(G_{j t}\right)\right)+\beta_{2}\left(\ln \left(P_{k t}\right)-\ln \left(P_{j t}\right)\right) . \\
& +\beta_{3}\left(D_{f k}-D_{f j}\right)+\varepsilon_{i k}-\varepsilon_{j 1}
\end{aligned}
$$

In turn, in case of loss-averse agents, we estimate:

$$
\begin{aligned}
& \ln \left(m s_{k t}\right)-\ln \left(m s_{j t-1}\right)=\beta_{k}-\beta_{j}+\beta_{1} \operatorname{pos} G_{k t}+\beta_{2} n e g G_{k t}+\beta_{3} p o s P_{k t}+\beta_{4} n e g P_{k t} \\
& +\beta_{5}\left(D_{f t}-D_{j t}\right)+\varepsilon_{i k}-\varepsilon_{j 1}
\end{aligned}
$$

Finally, in the last behavioral model, we assume that sales of cars show path-dependency. To account for this, we include $d s_{j t-1}$ as a dependent variable, which is the sum of market shares over different fuel versions of design $k$ at time $t-1$. Formally, the regression has the form of:

$$
\begin{aligned}
& \ln \left(m s_{k t}\right)-\ln \left(m s_{j t-1}\right)=\beta_{k}-\beta_{j}+\beta_{1}\left(\ln \left(G_{k t}\right)-\ln \left(G_{j t}\right)\right)+\beta_{2}\left(\ln \left(P_{k t}\right)-\ln \left(P_{j t}\right)\right)+\beta_{3}\left(D_{f k}-D_{f j}\right) \\
& +\beta_{4}\left(d s_{k t-1}-d s_{j t-1}\right)+\varepsilon_{i k}-\varepsilon_{j 1}
\end{aligned}
$$

The EU registration database does not include car prices. Subsequently, we collected data on the price of each car design in 2010 or 2011 (depending on the availability) from the Autoviva website with the exception to hybrid and electric cars, whose prices were collected from the press releases and manufacturers' websites. We impute (diesel and petrol) car prices in the missing years according to a formula:

$$
P_{k t}=P_{k t-1}\left(1+g+\varepsilon_{g}\right), \quad \text { for } f \in\{p, d\}
$$

where $g$ is the growth rate of prices, and $\varepsilon_{g}$ is a random variable. To estimate the annual grow of car prices, we collected prices of 80 car (petrol and gasoline) designs in 2006 from the EU annual report on car prices' 
comparison between EU countries, and compared them to prices in $2010^{3}$. On average, between 2006 and 2010 cars' prices grew by $19.4 \%( \pm 21 \%)$. This implies an annual price increase equal to $\mathrm{g}=4.5 \%$, while we set $\varepsilon_{g}$ to be drawn from $\mathrm{N}(0,0.05)$. We kept prices of electric and hybrid cars constant. Prices of electricity and fuels between 2010 and 2015 were collected from Eurostat.

The EU registration data includes data on efficiency of electric and hybrid cars $\mathrm{zwh}=(\mathrm{Wh} / \mathrm{km})$, but not on fuel economy of conventional cars. We compute fuel efficiency of diesel and petrol cars, using data on $\mathrm{CO}_{2}$ emissions $e k g_{j t}(\mathrm{~kg}$ per $\mathrm{km}$ ) reported for each car, following Ligterink et al. (2016):

$$
F C_{k t}=\frac{e k g_{k t}}{a}, \quad \text { for } f \in\{p, d\}
$$

where $\mathrm{a}=23.7$ if car is fueled by petrol, and $\mathrm{a}=26.5$ in case of diesel cars.

To calculate the discounted fuel cost in equation (2), we assume the discount rate equal to 0.069 , as estimated by Allcott and Wozny (2014). In case of hybrid vehicles, we estimate the discounted fuel costs based on costs in $50 \%$ of electric and $50 \%$ of petrol vehicles.

Table 1 reports estimates of coefficients in different behavioral utility functions. In particular, it summarizes the results from the panel regression models with fixed-effects and AR(1) disturbances. This is motivated by the fact that we find that the data suffers from autocorrelation $(\mathrm{F}(1,322)=337.55)$, thus we included AR(1) disturbances to correct for this problem. In turn, the Hausman test indicates that the model with fixed effects is favorable over the model with random effects. Models 3 and 6 present the results from regressions with random effects, as the fixed-effect model does not allow to examine the impact of time invariant variables. However, in the out-of-the sample predictions (see Section 2.1.3), we use results from the fixed-effect models.

The results in Table 1 support that consumers undervalue expenses on fuel compared to the vehicle price. In particular, we find that the coefficient corresponding to the vehicle price is six time larger than the coefficient corresponding to the discounted fuel cost in Model 3, confirming the myopia of consumers. ${ }^{4}$ Moreover, the discounted fuel cost is statistically insignificant in explaining the probability that consumers purchase a specific car design (Models 2 and 3). In turn, the results from the model of loss-averse consumers indicate that the discounted fuel cost matters, but only if it is larger than the fuel cost of the comparison design (Models 4 and 5). In favor of this, the coefficient corresponding to the positive difference in the

\footnotetext{
${ }^{3}$ The last issue was issued in 2006.

${ }^{4}$ The difference in coefficients between the discussed variables exceeds estimates from the preceding studies. This can be explained by the fact that we include in our database electric and hybrid vehicles, which has not been done before. Moreover, our estimations do not account for the endogeneity of car prices. Because of a lack of data, we had to impute values of vehicle prices based on historical patterns, thus our data do not account for how they change depending on the changes in fuel costs.
} 
discounted fuel costs between $k$ and $j$ designs has a negative and statistically significant impact on the probability of adoption of $k$ design.

Similarity, the coefficient corresponding to the positive difference between the vehicle price of $k$ and $j$ designs has a negative and statistically significant impact on the shares of $k$ design, indicating that more expensive cars have a lower probability of being purchased. In turn, the opposite does not hold. We find that the absolute negative difference between vehicle prices, or between discounted fuel costs (of $k$ and $j$ designs) have an insignificant impact on market shares of design $k$ (with the exception to the difference in the discounted fuel cost in Model 5). This suggests that more expensive options are less likely to be bought, but less expensive products are evaluated against other criteria than financial expenses by decision makers. Finally, the results from Model 6 indicate that past sales have a statistically significant and positive impact on future car sales, supporting that consumer inertia and habits play a role in explaining car purchases. 
Table 1. Determinants behind demand for different car designs in alternative behavioral models. The results from panel regressions, with the dependent variable: $\ln \left(s_{j t}\right)-\ln \left(s_{0 t}\right)$, with $\mathrm{AR}(1)$ disturbances.

\begin{tabular}{|c|c|c|c|c|c|c|}
\hline & $\begin{array}{l}\text { Model } 1 \\
\text { Rational } \\
\text { agents } \\
\text { (a fixed- } \\
\text { effects } \\
\text { model) }\end{array}$ & $\begin{array}{l}\text { Model } 2 \\
\text { Myopic } \\
\text { agents } \\
\text { (a fixed- } \\
\text { effects } \\
\text { model) }\end{array}$ & $\begin{array}{l}\text { Model } 3 \\
\text { Myopic } \\
\text { agents } \\
\text { (a random- } \\
\text { effects } \\
\text { model) }\end{array}$ & $\begin{array}{l}\text { Model } 4 \\
\text { Loss-averse } \\
\text { Agents } \\
\text { (a fixed- } \\
\text { effects } \\
\text { model) }\end{array}$ & $\begin{array}{c}\text { Model } 5 \\
\text { Loss-averse } \\
\text { agents } \\
\text { (a random } \\
\text { effects } \\
\text { model) }\end{array}$ & $\begin{array}{l}\text { Model } 6 \\
\text { Habit- } \\
\text { followers } \\
\text { (a fixed- } \\
\text { effects } \\
\text { model) }\end{array}$ \\
\hline $\ln \left(p_{k t}\right)-\ln \left(p_{j t}\right)$ & & $\begin{array}{l}-2.22 * * * \\
(0.52)\end{array}$ & $\begin{array}{c}-0.69 * * * \\
(0.16)\end{array}$ & & & $\begin{array}{l}-1.10^{* * *} \\
(0.48)\end{array}$ \\
\hline $\ln \left(G_{k t}\right)-\ln \left(G_{j t}\right)$ & & $\begin{array}{l}-0.26 \\
(0.18)\end{array}$ & $\begin{array}{l}-0.11 \\
(0.17)\end{array}$ & & & $\begin{array}{c}0.06 \\
(0.17)\end{array}$ \\
\hline $\begin{array}{l}\text { The positive difference of } \\
\ln \left(p_{k t}\right)-\ln \left(p_{j t}\right)\end{array}$ & & & & $\begin{array}{c}-2.37 * * * \\
(0.56)\end{array}$ & $\begin{array}{c}-0.79 * * * \\
(0.17)\end{array}$ & \\
\hline $\begin{array}{l}\text { The absolute negative diff of } \\
\ln \left(p_{k t}\right)-\ln \left(p_{j t}\right)\end{array}$ & & & & $\begin{array}{c}0.83 \\
(1.72)\end{array}$ & $\begin{array}{l}-1.13 \\
(1.08)\end{array}$ & \\
\hline $\begin{array}{l}\text { The positive difference of } \\
\ln \left(G_{k t}\right)-\ln \left(G_{j t}\right)\end{array}$ & & & & $\begin{array}{c}-0.83 * * * \\
(0.29)\end{array}$ & $\begin{array}{c}-1.42 * * * \\
(0.29)\end{array}$ & \\
\hline $\begin{array}{l}\text { The absolute negative diff of } \\
\ln \left(G_{k t}\right)-\ln \left(G_{j t}\right)\end{array}$ & & & & $\begin{array}{l}-0.25 \\
(0.27)\end{array}$ & $\begin{array}{l}-1.11 * * * \\
(0.28)\end{array}$ & \\
\hline $\begin{array}{l}\text { Total cost } \\
\ln \left(G_{k t}+p_{k t}\right)-\ln \left(p_{j t}+G_{j t}\right)\end{array}$ & $\begin{array}{c}-0.45^{* * *} \\
(0.17)\end{array}$ & & & & & \\
\hline Past sales $d s_{k t-1}$ & & & & & & $\begin{array}{c}0.35^{* * * *} \\
(0.23)\end{array}$ \\
\hline $\begin{array}{l}\text { Dummy taking value } 1 \text { for } \\
\text { electric and hybrid cars }\end{array}$ & & & $\begin{array}{c}-3.10^{* * * *} \\
(0.40) \\
\end{array}$ & & $\begin{array}{c}-2.71 * * * \\
(0.39) \\
\end{array}$ & \\
\hline Constant $\beta_{k}-\beta_{j}$ & $\begin{array}{l}-2.29 \\
(0.06) \\
\end{array}$ & $\begin{array}{c}-1.21 * * * \\
(0.15) \\
\end{array}$ & $\begin{array}{c}-2.07 * * * \\
(0.12) \\
\end{array}$ & $\begin{array}{c}-0.94 * * * \\
(0.17) \\
\end{array}$ & $\begin{array}{c}-1.64 * * * \\
(0.15) \\
\end{array}$ & $\begin{array}{c}-1.89 * * * \\
(0.16)\end{array}$ \\
\hline $\begin{array}{ll}\text { R-sq } & \text { - within } \\
& \text { - between } \\
& \text { - overall } \\
\end{array}$ & $\begin{array}{l}0.01 \\
0.05 \\
0.04\end{array}$ & $\begin{array}{l}0.02 \\
0.06 \\
0.05\end{array}$ & $\begin{array}{l}0.00 \\
0.19 \\
0.09\end{array}$ & $\begin{array}{l}0.02 \\
0.08 \\
0.06\end{array}$ & $\begin{array}{l}0.01 \\
0.25 \\
0.12\end{array}$ & $\begin{array}{l}0.14 \\
0.33 \\
0.35\end{array}$ \\
\hline $\mathrm{Nr}$ of observations & $\begin{array}{c}341 \\
1353\end{array}$ & $\begin{array}{c}341 \\
1353\end{array}$ & $\begin{array}{c}341 \\
1353\end{array}$ & $\begin{array}{c}341 \\
1353\end{array}$ & $\begin{array}{c}478 \\
1831\end{array}$ & $\begin{array}{c}323 \\
1012\end{array}$ \\
\hline
\end{tabular}

Note: standard deviations in parenthesis; ${ }^{* * *}$ indicates variables significant at the 1 percent level, $* *$ at the 5 percent level, and $*$ at the 10 percent level

\subsubsection{Out-of-the sample predictions}

We simulate the evolution of market shares of different car designs after 2015 as follows. For each behavioral model, we first compute the mean utility from purchasing design $k \delta^{b e h}{ }_{k t}$ (compared to the outside good normalized to zero) as:

$$
\delta_{k t}^{b e h}=\left(\beta_{k}-\beta_{j}\right)\left(X_{k t}-\hat{X}_{j}\right)+\varepsilon_{i k}-\varepsilon_{j 1},
$$

where the utility $\delta^{b e h}$ is computed numerically using product characteristics $X$ as specified in equations $(8 a-d)$ and parameters reported in Table 1 for each behavioral model. As comparison values for design $j$ 
$\hat{X}_{j}$, we use in our calculations mean characteristics over 2010-2015 of FIAT 5005. Subsequently, we calculate the market share of design $k$ after 2015 using the logit formula:

$$
d_{k t}\left(\delta^{b e h}{ }_{k t}\right)=\frac{\exp *\left(\delta^{b e h}{ }_{k t}\right)}{\sum_{j} \exp *\left(\delta^{b e h}{ }_{j t}\right)} \cdot{ }^{6}
$$

We assume a cohort of $m=3$ million consumers entering the market at each time $t^{7}$. The cohort leaves the market after $T_{L}=10$ years, which is the average lifetime of newly purchased cars in Germany (Kalinowska and Kuhfeld, 2006). The distribution of newly purchased car designs changes over time (between cohorts) because of changes in fuel prices as well as improvements in fuel efficiencies of different vehicles. We keep the price of vehicles constant after 2015 equal to their historical values. In model simulations, the prices of fuels (gasoline and petrol) follow random walk: $p_{f t+1}=p_{f t}+\xi_{f}$, with variable $\xi_{f}$ being drawn from $\mathrm{N}(0,0.14)$ for $f \in\{p, d\}$ and $\mathrm{N}(0,0.01)$ for electric cars. Here, 0.14 and 0.01 are standard deviations of gasoline and electricity prices between 2010 and 2015 in Germany, estimated using data from the Eurostat, respectively.

The evolution of fuel economies of different designs is essential for assessing future emissions. We assume that fuel efficiencies improve over time according to the equation:

$$
\begin{aligned}
& F C_{k t}=F C_{k t-1}\left(1+g_{F C}+\varepsilon_{F C}\right) \quad \text { if } \quad \mathrm{FC}_{\mathrm{j}} \geq 3 \\
& F C_{f t}=38 \quad \text { otherwise }
\end{aligned}
$$

The growth of fuel efficiency equals $g_{F C}=-0.04$ for diesel and $g_{F C}=-0.03$ for petrol cars to match improvements in mean fuel efficiency observed in the data, whereas $\varepsilon_{F C}$ is a random variable drawn from $\mathrm{N}(0,0.01)^{9}$. Figures 1(a) and (b) compare distributions of fuel efficiencies in 2010 and 2015 registered in Germany of petrol and diesel cars respectively, based on which we forecast changes in fuel efficiencies after 2015. The figures illustrate that between 2010 and 2015, mean fuel efficiency of diesel cars improved, i.e. it fell from 5.67 to $4.87 \mathrm{~L} / 100 \mathrm{~km}$. In case of petrol cars, mean values of fuel efficiencies were in 2010 and 2015 respectively 7.22 and $6.01 \mathrm{~L} /(100 \mathrm{~km})$.

\footnotetext{
${ }^{5}$ The mean value of the market share of the petrol version of the FIAT 500 was equal to 0.01 between 2010 and 2015, the mean value of the logarithm of vehicle price was equals to 9.47 , and the mean value of the discounted fuel costs was 8.98 .

${ }^{6} m s_{k t}$ is a market share of car design $k$ in the dataset between 2010-2015, which is used to estimate parameters in the utility functions. In turn, $\mathrm{d}\left(\delta_{k t}\right)$ is the simulated market share after 2015.

${ }^{7}$ The number of new drivers each year is important for the assessment of total emissions from car transport.

${ }^{8}$ We assume that fuel efficiency cannot fall below 3 in model simulations, which constitutes a maximum efficiency frontier in our simulations

${ }^{9}$ To compute annual rates of improvements in fuel efficiencies $\mathrm{g}_{\mathrm{FC}}$, we solved equations for petrol and diesel car separately: $\mathrm{FC}_{2015}=\mathrm{FC}_{2015}\left(1-\mathrm{g}_{\mathrm{FC}}\right)^{5}$, where $\mathrm{FC}_{2015}$ and $\mathrm{FC}_{2010}$ are mean fuel efficiencies in 2015 and 2010.
} 


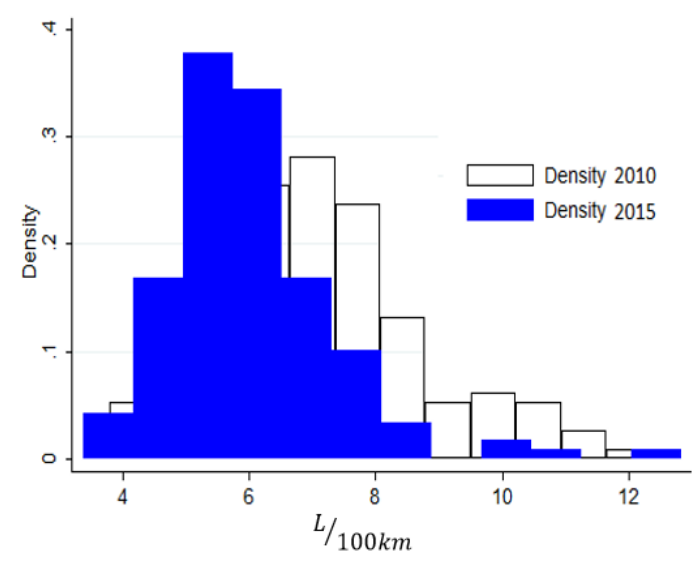

(a) Fuel efficiency of petrol cars

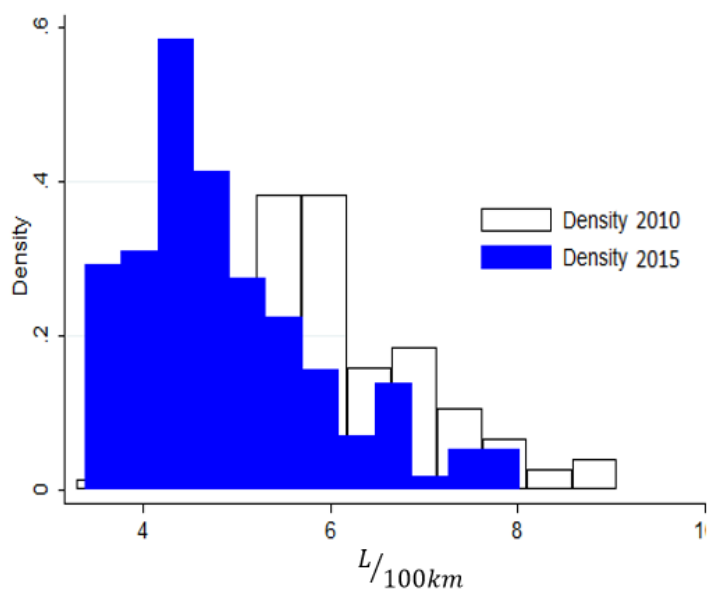

(b) Fuel efficiency of diesel cars

Figure 1.The distributions of fuel efficiencies of cars registered in Germany in 2010 and 2015

\subsection{Behavioral models of driving behavior}

Total emissions from car transport rely not only on the car choice and its fuel efficiency, but also how drivers modify distances travelled depending on changes in fuel prices. We consider three types of car driving behavior: with (1) rational; (2) habit-following; and (3) loss-averse drivers. In particular, we assume that rational agents, owners of car design $k$, maximize indirect utility, which is a function modified from Holland et al. (2016):

$$
\begin{aligned}
& V_{k t}=\max _{y, x_{k}} y+f\left(x_{k t}\right) \\
& \text { subject to } f c_{k t} x_{k t} p_{e t}+y=I \text { for } f \in\{p, d\}
\end{aligned}
$$

where $f\left(x_{k t}\right)=\frac{x_{k t}^{1-\gamma}}{1-\gamma}$ is utility from kilometers $x_{k t}$ travelled, and $f c_{k t}$ is the unit fuel efficiency (petrol, gasoline or electricity) expressed in terms of litters of fuel needed per $1 \mathrm{~km} ; I$ is annual income and $y$ are other annual expenses. According to equation (12), consumers maximize the utility from driving and from consumption of a composite good $y$ with price normalized to 1 , given their budget constraints.

Substituting $f\left(x_{k t}\right)=\frac{x_{k t}^{1-\gamma}}{1-\gamma}$ into the maximization problem (12) and then solving for $x_{k t}$, gives the demand for kilometers (see also Michalek et al., 2011; Holland et al., 2016):

$$
x_{k t}=\left(\frac{a_{k l}}{f c_{k l} p_{f t}}\right)^{\frac{1}{\gamma}}
$$

\footnotetext{
${ }^{10}$ In case of hybrid cars, the demand for fuel equals $50 \%$ of demand for conventional fuels and $50 \%$ of electricity.
} 
where, $f c_{k l}$ is fuel efficiency of car design $k$, which was purchased by consumers from the cohort $l$. We follow the methodology proposed in Holland et al. (2016) to estimate parameter $a_{k T}$. In particular, we substitute $\gamma=2$, which gives the elasticity for kilometers equal $1 / \gamma=0.5$, and $x_{k l}=13500 \mathrm{~km}$, which is the expected annual distance driven in Germany by an average driver (Kalinowska and Kuhfeld, 2006), and insert these values into equation 13 to derive $a_{k T}$. The parameter value differs between owners of alternative designs because of differences in their fuel efficiencies. In addition, the parameter varies between car owners of the same design, but coming from different cohorts, as new cars entering the market are characterized by improved fuel efficiencies.

A second behavioral model of driving behaviour is habit formation, where current utility depends on a "habit stock" formed by past values of distances travelled. The basic idea here is that consumers dislike changes to their consumption levels, in particular changes in kilometers traveled each year. This model has not been used yet for forecasting demand for travel despite empirical studies indicating that habits affect consumers' response to changes in fuel costs. For instance, Frondel and Vance (2013) find that households react to the increases in fuel price by reducing driving, and maintain the new behaviours even when prices fall to their original levels.

Formally, the utility function can be modified to account for the impact of habits on utility (following Carroll et al., 2000):

$$
u\left(x_{k t}\right)=\frac{\left(\frac{x_{k t}}{h_{k t}{ }^{1-\gamma}}\right.}{1-\gamma},
$$

where $\sigma$ measures the importance of habits $h_{k t}$. Their evolves according to $\dot{h}_{k t}=\rho\left(x_{k t}-h_{k t}\right)$, where the habit stock is the weighted average of past kilometers driven, with the parameter $\rho$ describing the relative weights attached to distances commuted at different times. After substituting function (14) into maximization problem in (12), we derive the demand for kilometers $x_{k t}$ by habit-oriented car owners as:

$$
x_{k t}=h_{k t}^{\sigma}\left(\frac{a_{k T}}{f c_{k T} p_{f t}}\right)^{\frac{1}{\gamma}} h_{k t}^{-\frac{\sigma}{\gamma}},
$$

where parameter $a_{k T}$ is the same as in case of rational consumers. In model simulations, we assume the strength of habits $\sigma=0.5$, and weights attached to the past travel distances to be equal to $\rho=0.1$.

A third model of driving behaviour reflects loss aversion on the side of consumers (Ahrens et al., 2017). The basic idea here, which is line with prospect theory, is that consumers perceive utility losses from reductions in commuted distances differently than the perceived utility gains from an increase in distances travelled. The previous results show that changes in, and volatility of, gasoline prices affect the elasticity 
of demand for gasoline (Lin and Prince, 2013). We model it formally here in a way that the elasticity of demand for kilometers $(1 / \gamma)$ changes over time depending on prior distances travelled. In particular, the coefficient $\gamma$ for loss-averse owners of design $k$ evolves over time according to:

$$
\begin{array}{ll}
\gamma_{k t}=\gamma_{k t-1}\left(\frac{x_{k t}}{x_{k t-1}}\right)^{\beta} & \text { if } \quad x_{k t-1} \neq x_{k t}, \\
\gamma_{k t}=\gamma_{k t-1} & \text { otherwise. }
\end{array}
$$

We assume that $\gamma_{k t}$ cannot fall below its minimum value $\bar{\gamma}_{\min }(=1.75)$ as well as it cannot exceed its maximum value of $\bar{\gamma}_{\max }(=2.2)$, while we set $\beta=0.025$. As a result, the elasticity of demand decreases if a consumer drove more at time $t$ compared to the previous period. In turn, if she commuted less compared to the prior distance, her elasticity of demand for kilometers would increase, and subsequently she will commute more in the future period. This is motivated by the experimental evidence that a prior loss induces a risk seeking behavior (Kahneman and Tverskym 1979).

\subsection{The electricity market (electricity production)}

On the electricity market, production of electricity is carried out in heterogeneous plants $i$ characterized by age $s_{i t}$, specific productivity $v_{i t}$ and energy source $j$, installed capacity $k_{i}$, maximum lifespan ${ }^{11} T_{j}$, and capacity factor $\lambda_{j}$. The latter captures periods of decreased production due to economic reasons (low profitability), obligatory maintenance, etc. Initially, the market is composed of coal, gas, nuclear, biomass, wind and solar to reflect the diversity mix of fuels in electricity generation in Germany at the beginning of 2010 (EU, 2013). ${ }^{12}$ We ignore in model simulations oil, hydropower and geothermal energy, which shares are negligible in electricity production.

The structure of dynamics on the electricity market is as follows. At the beginning of each year $t$, plants set their production $q_{i t}$ (given the capacity constraint $q_{i t}<\lambda_{i} k_{i}$ ) so as to maximize profits:

$$
\Pi_{i t}=p_{e t} q_{i t}-m_{i t} q_{i t}-F_{i t}
$$

$p_{e t}$ is the spot market price determined by a static demand function (below), $m_{i t}$ is a marginal cost of plant $i$, and $F_{i t}$ represents its fixed cost. The fixed cost fix costs capture costs of electricity production which plants incur regardless of the levels of their production

The electricity price is determined by an inverse demand function:

$$
p_{e t}=a-D_{t}+\theta
$$

\footnotetext{
${ }^{11}$ The maximum lifetimes of plants operating at time 0 were drawn randomly from the uniform distribution over the range $(10,50)$.

${ }^{12}$ In particular, we assume that: $35 \%$ of electricity is generated from coal, $11 \%$ from gas, $29 \%$ from nuclear, $22 \%$ from biomass, $2 \%$ from wind and $1 \%$ from solar power stations.
} 
where demand $D_{\mathrm{t}}$ is equal to a total supply: $D_{t}=Q_{t}=\sum_{i} q_{i t}$, and $a$ and $b$ are parameters. $\theta$ is a random variable drawn from normal distribution $N(0,1)$. Consequently, $E(\theta)=0$.

The production decision by electricity plants is modeled as a Cournot game (Allaz, 1992; Allaz and Vila, 1993). Accordingly, each plant decides how much output to produce so as to maximize profits (derived from $\left.\frac{\partial \pi_{i t}}{\partial q_{i t}}=0\right)$ :

$$
q_{i t}=\frac{a+\theta-\left(n_{t}+1\right) m_{i t}+M_{t}}{\left(n_{t}+1\right) b} .
$$

Here, $n_{t}$ is the number of power plants operating at time $t . M_{t}$ is a sum of marginal costs of all power plants operating at time $t$.

A plant exits once $s_{i t}>T_{j}$ where $T_{j}$ is the expected lifetime of a plant (defined for each energy technology. If the owner decides to close the plant, he loses its production capacity forever (Atkeson and Kehoe, 2007).

After setting production and their forward positions, plants decide how many inputs for production to employ so as to minimize total input costs. Electricity production by plant $i$ using technology $j$ is described by the Cobb-Douglas function (Nerlove, 1963):

$$
q_{i t}=a_{i t} i_{K i t}^{\alpha_{K j}} i_{L i t}^{\alpha_{L j}} i_{F i t}^{\alpha_{F j}}
$$

where $a_{i t}$ is the plant's specific productivity; $i_{K i^{*}}, i_{L i^{*}}, i_{F^{*}}$ describe capital, labour and fuel input respectively. $\alpha_{K j}, \alpha_{L j} \alpha_{F j}$ are corresponding substitution factors associated with technology $j$, where $\alpha_{K j}+\alpha_{L j}+\alpha_{F j}=1$.

The parameter $a_{i t}$ is equal to $\left(\frac{1}{v_{i t}}\right)^{\alpha_{F j}}$, where $v_{i t}$ is a thermal efficiency with which a plant can transform fuel into heat (energy). The thermal efficiency, which is a measure of plants' productivity, can improve over time. Before each period, a random shock is drawn from the technology-specific distribution $\varepsilon_{i} \sim N\left(\mu_{i}, \sigma_{i}^{2}\right)$. A plant starts operating in the next period with a productivity equal to $v_{i t+l}=v_{i t}+\varepsilon_{t}$. This captures learning-by-doing: the longer the plant exists in the market the more efficiently it transforms basic energy inputs into electricity.

Under the assumption that inputs are allocated according to their marginal productivity, inputs are equal:

$$
i_{K i t}=\frac{\alpha_{K j} p_{F j t}}{p_{K j t} \alpha_{F j}} i_{F t} v_{i t}, i_{L i t}=\frac{\alpha_{L j} p_{F j t}}{p_{L t} \alpha_{F j}} i_{F t} v_{i t} \text {, and } i_{F i t}=q_{i t} \frac{\alpha_{F j}}{p_{F j t}} \frac{p_{K i t}^{\alpha_{K j}} p_{l t}^{\alpha_{L j}} p_{F j}^{\alpha_{F j}}}{v_{i t} \alpha_{K j}^{\alpha_{K j}} \alpha_{L j}^{\alpha_{L j}} \alpha_{F j}^{\alpha_{F j}}},
$$


where $p_{K t}, p_{L j t}$, and $p_{F j t}$ and the prices of capital, labour and fuel $j$ at time $t$ respectively. We assume that the price of labour is equal to unity. This is a simplification, which allows us to examine impacts of relative changes in the price of fuel to labour on model dynamics.

Prices of fuels change over time. In particular, fuel prices follow a geometric Brownian motion (Brand and Kinlay, 2007):

$$
d p_{F j t}=\chi_{j} d t+\sigma_{j} d Z_{t}
$$

where $\sigma$ is the volatility of fuel price $j, Z_{t}$ is a Wiener process and $\chi$ is a drift.

The marginal cost of plant $i$ employing technology $j$ is equal to:

$$
m_{i t}=\frac{\left(v_{i t} \alpha_{L j}+v_{i t} \alpha_{K j}+\alpha_{F j}\right) \alpha_{F j}^{\alpha_{K j}+\alpha_{L j}}\left(p_{K j t}+p_{L t}\right)^{\alpha_{K j}+\alpha_{L j}}}{v_{i t} \alpha_{F j}\left(\alpha_{K j} p_{K t}\right)^{\alpha_{K j}}\left(\alpha_{L j} p_{L t}\right)^{\alpha_{L j}}}
$$

where $p_{j}^{o}$ is the operating cost of technology $j$.

In the beginning of each period, a new power plant enters the market. Formally, a planner evaluates capacity $k_{i j}$ maximizing expected profits $V_{i j}$ for each energy technology $j$ :

$$
\begin{aligned}
& V_{i j}=E\left[\left(\sum_{t=t_{s j}}^{T+t_{s j}} e^{-r t}\left(p\left(\lambda 8760 k_{i j}\right)-\hat{m}_{j t}\right) 8760 \lambda k_{i j}-e^{-r t_{s}} I_{j} k_{i j}\right)\right] \\
& =\frac{-1}{-1+e^{r}}\left(e ^ { - r ( T + 2 t _ { s } ) } ( - 1 + e ^ { r + T r } ) k _ { i j } \left(I_{j}+8760 e^{r t_{s}} \lambda\left(c-p\left(k_{i j}\right)\right)\right.\right.
\end{aligned}
$$

Here, $I_{j}$ is a fixed cost per $\mathrm{KW}$ of installed capacity $k_{i j}$ capturing initial investment costs and maintenance expenses. These costs need to be covered from the revenues over the entire life of the plant $T_{j}$. Furthermore, $t_{s j}$ indicates the number of years before plant $i$ (embodying technology $j$ ) can be operationalized, $\hat{m}_{j t}$ is the expected marginal cost associated with technology $j$ at time $t+1$ (best frontier technology), and $r$ is an interest rate. A new plant starts operating in $t+t_{s j}$. It embodies technology $j$ that ensures the highest value $V_{i j}$.

An optimal level of installed capacity $k_{i j}$ equals (derived from $\frac{\partial V_{i j}}{\partial k_{i j}}=0$ ):

$$
k_{i j}=\frac{-I_{j} e^{-r t_{s}}+\lambda_{j} 8760\left(a-b Q_{-i}-\hat{m}_{j}\right)}{153475200 b \lambda_{j}^{2}},
$$

where $Q_{-i}$ indicates the expected level of production without a new plant.

${ }^{13}$ This has been derived under the assumption that a plant can produce $8760 \lambda_{i} k_{i}$ MWh electricity per year. 


\subsubsection{Empirical validation of the electricity market}

The parameters describing different energy technologies, such as gas, coal, nuclear, biomass, wind and solar energy, are calibrated on data for the electricity industry in the Germany between 2010-2015 - as summarized in Table 2. The data on costs and technical characteristics of energy technologies in Germany are collected from Kost et al. (2013). The data on operating costs and load capacities are equal to OECDmean values from IEA (2010). Finally, we have not found reliable data on the operating cost and the installation cost of nuclear power plants in Germany, and thus we assumed specific values from the realistic value ranges. In addition, we set realistic values regarding mean growth rate in thermal efficiencies. In turn, mean values and standard deviations in fuel prices were estimated based on data from FSO (2017) between 2008 and 2016. The elasticities of substitution between factors in production for coal, gas and nuclear energy are based on Safarzynska and van den Bergh (2011). For other renewable energy technologies, we assume that production of electricity from renewable energy sources is capital intensive with $\alpha_{\mathrm{K}}=0.8$ and $\alpha_{\mathrm{L}}=0.2$.

Table 2. Basic features of energy technologies

\begin{tabular}{|c|c|c|c|c|c|c|c|}
\hline $\begin{array}{l}\text { Energy } \\
\text { technology i }\end{array}$ & Description & coal & nuclear & gas & biomass & wind & solar \\
\hline$\alpha_{k}$ & $\begin{array}{l}\text { Elasticities of } \\
\text { substitution }\end{array}$ & 0.452 & 0.876 & 0.2 & 0.8 & 0.8 & 0.8 \\
\hline$\alpha_{1}$ & & 0.077 & 0.035 & 0.07 & 0.2 & 0.2 & 0.2 \\
\hline$\alpha_{\mathrm{e}}$ & & 0.471 & 0.089 & 0.73 & - & - & - \\
\hline $\mathrm{v}_{\mathrm{i} 0}$ & Initial thermal efficiency & $45 \%$ & $33 \%$ & $60 \%$ & - & - & - \\
\hline $\max v_{i t}$ & Maximum thermal efficiency & $55 \%$ & $33 \%$ & $70 \%$ & - & - & - \\
\hline$\chi-0.5 \sigma_{j}^{2}$ & $\begin{array}{l}\text { Mean value of changes in fuel } \\
\text { prices }\end{array}$ & -0.03 & - & -0.06 & - & - & - \\
\hline$\sigma_{\mathrm{j}}$ & $\begin{array}{l}\text { Standard deviations of changes in } \\
\text { fuel prices }\end{array}$ & 0.09 & - & 0.09 & - & - & - \\
\hline $\mathrm{p}_{\mathrm{j} 0}$ & Initial price of fuel $(\mathrm{E} / \mathrm{kWh})^{14}$ & 0.011 & 0.006 & 0.029 & - & - & - \\
\hline $\mathrm{T}_{\mathrm{j}}$ & Maximum lifespan & 40 & 60 & 30 & 20 & 20 & 25 \\
\hline $\mathrm{p}_{j}^{\circ}$ & Operating cost $(\mathrm{E} / \mathrm{kWh})$ & 0.009 & 0.006 & 0.004 & 0.028 & 0.025 & 0.036 \\
\hline$F_{j t}$ & Fixed cost $(\mathrm{E} / \mathrm{kW})$ & 34 & 100 & 22 & 175 & - & 35 \\
\hline$t_{\mathrm{sj}}$ & Construction time & 4 & 7 & 2 & 1 & 1 & 1 \\
\hline $\mathrm{I}_{\mathrm{j}}$ & Initial investment cost $(\mathrm{E} / \mathrm{kW})$ & 1175 & 1200 & 550 & 3000 & $2200^{15}$ & 1100 \\
\hline$\lambda_{j}$ & Capacity factor & $85 \%$ & $85 \%$ & $85 \%$ & $85 \%$ & $33 \%^{15}$ & $11 \%$ \\
\hline Emission $\mathrm{CO}_{2 \mathrm{j}}$ & Emissions $(\mathrm{kg} / \mathrm{kWh})$ & 0.35 & - & 0.2 & -- & - & - \\
\hline
\end{tabular}

${ }^{14}$ We impose boundary conditions on fuel prices $(0.005,1)$.

15 The mean value between on- and off-shore wind. 


\section{Results from the model simulations}

In this section, we study the impact of policies aimed at reducing $\mathrm{CO}_{2}$ emissions from the household passenger transport sector, and we compare their effectiveness depending on consumer's buying and driving behavior. The calculations of the total emissions from the transport sector include a part of emissions from electricity generation, namely due to production of electricity used to fuel electric cars. We study total transport emissions for four distinct behavioural models of vehicle adoption: (1) rational (AR), (2) myopic (AM), (3) habitual (AH), and (4) loss-averse consumers (AL). This is combined with three behavioral models of use or demand for kilometers, namely: (1) rational (DR), (2) habitual (DH), and (3) loss-averse drivers (DL). In total, our design gives rise to 12 different combinations of behavioral models of car choice and driving. It constitutes the first study, which compares systematically how different types of boundedly-rational behaviors affect emissions from car transport.

The total emissions from the transport sector at time $t$ are equal to:

$$
T E_{t}=\sum_{l=1 . . T_{L}} \sum_{k=1 . . n} m * x_{l k t} * e k g_{l k t} * m s_{k l}
$$

where $m$ is the number of new cars entering the German market annually, ekg $_{l k t}$ is the emission factor measuring $\mathrm{kg}$ of $\mathrm{CO}_{2}$ per $\mathrm{km}$ associated with design $k$ bought at time $l, x_{i k l t}$ is the distance travelled by owners of design $k$ from cohort $l$ at time $t$, and finally $m s_{l k}$ is the share of $k$ design in cohort $l$. In case of electric vehicles, the emission factor is equal to $\mathrm{CO}_{2}$ emissions per $\mathrm{kWh}$ of electricity produced multiplied by the electricity efficiency of design $k$ from cohort $l$. The emission factor associated with production of electricity changes over times, depending on the fuel mix in electricity production.

We consider two energy scenarios, which differ with respect to energy mixes in electricity generation, so as to compare the impact on increasing the share of renewable energy in electricity production on the electricity price and the rate of adoption of electric cars. In the 2010 scenario, we assume that current energy mix is extrapolated into the future. Formally, the choice of fuel to be embodied in a new power plant is chosen randomly with the probability equal to the historical share of different fuels in electricity generation in Germany in 2010. In the second scenario, to which we will refer as the 2050 scenario, we study the impact of abandoning coal and nuclear energy, and replacing them by renewable energy, on the electricity price. Formally, we model this as fuels to be embodied in new power plants being chosen with the probability equal to their projected shares in electricity generation in 2050 (see Figure 3 and Appendix A). Typically, the existing studies compare emissions from car sector projecting the current energy mix into a future, which would correspond to the 2010 scenario. 


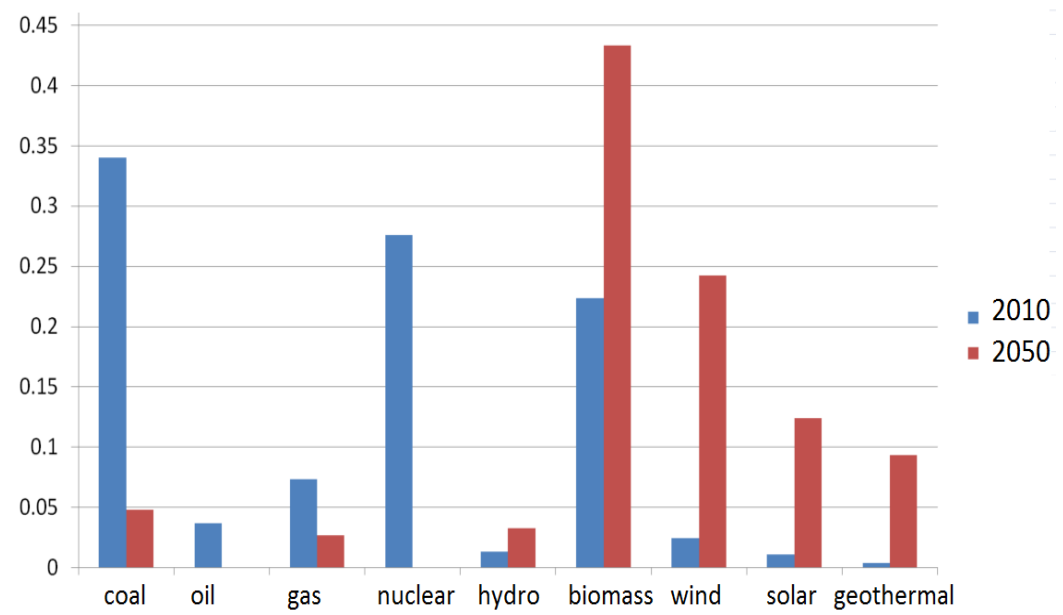

Figure 2. Actual and projected shares of electricity produced in Germany in 2010 and 2050, by fuel (Source: EU, 2013)

Additionally, we compare the rate of adoption of electric cars in three subsidy scenarios: (1) with no subsidy; (2) with the " $€ 5000$ subsidy" scenario, where consumers receive $€ 5000$ for the purchase of an electric vehicle, which is equal to the current value of the subsidy in Germany; and (3) "the optimal subsidy", where the subsidy is calculated according to the formula, modified from Holland et al. (2016):

$$
s_{t}^{*}=\left(\delta_{c t}-\delta_{e t}\right) * \hat{x}
$$

where $\hat{x}$ is the expected distance commuted over the vehicle lifetime $(135000 \mathrm{~km})$; and $\delta_{c t}-\delta_{e t}$ captures the difference in marginal damages between the conventional and electric vehicles. Formally, $\delta_{c t}$ and $\delta_{e t}$ are the costs of $\mathrm{CO}_{2}$ emissions associated with driving one $\mathrm{km}$ of an average conventional and electric car at time $t$, which are calculated as: $\delta_{c t}=P_{s c c} * e k g_{t}$ and $\delta_{e t}=P_{s c c} z w h_{t}$, where $P_{s c c}$ is the social cost of carbon ( $€$ per $\mathrm{kg}$ of $\mathrm{CO}_{2}$ emissions); $e k g_{t}$ are mean emissions from driving $1 \mathrm{~km}$ by conventional cars present on the market at time $\mathrm{t}$; and $z w h_{t}$ denotes mean emissions per $\mathrm{km}$ from driving electric cars, which depends on the fuel mix in the electricity sector.

\subsection{The total emissions from car transport under different behavioral assumptions}

Table 3 summarizes mean annual emissions from car transport over 50 years from 100 simulations for each behavioral model. We run 100 simulations with different initial seeds because of the presence of stochastic 
factors (see Tables B.1.-B.6. in Appendix B). Each time step is interpreted as a year. The results in Table 3 indicate that the rational model of adoption combined with the rational model of driving predicts the lowest emissions from car transport regardless of the energy scenario. In turn, the forecasts from the model with habit-oriented consumers (of car choice and driving) are the least optimistic. This can be explained by the fact that habitual consumers buy the least fuel efficient cars (see Section 4.). In addition, they commute more than other types of drivers. Whereas all commuters increase the demand for travel after fuel prices drop, habitual consumers take the longest to reduce their demand after the fuel prices increase again, overall commuting larger distances on average than rational and loss-averse drivers (see Figure 3).

Table 3. Mean annual $\mathrm{CO}_{2}$ emissions from the household transport sector from 100 simulations [million metric tonners]

\begin{tabular}{|c|c|c|c|c|c|c|c|c|c|c|c|c|}
\hline \multirow{2}{*}{$\begin{array}{l}\quad \begin{array}{l}\text { Model of } \\
\text { adoption }\end{array} \\
\text { Model of } \\
\text { driving* }\end{array}$} & \multicolumn{3}{|c|}{ Rational (AR) } & \multicolumn{3}{|c|}{ Loss-averse (AL) } & \multicolumn{3}{|c|}{ Myopic (AM) } & \multicolumn{3}{|c|}{ Habits (AH) } \\
\hline & $\mathrm{DH}$ & DL & $\mathrm{DR}$ & $\mathrm{AH}$ & DL & DR & DH & DL & DR & $\mathrm{DH}$ & $\mathrm{DL}$ & $\mathrm{DR}$ \\
\hline scenario 2010 & 41.25 & 37.67 & 37.83 & 44.89 & 41.03 & 41.05 & 44.66 & 40.02 & 40.10 & 47.56 & 44.38 & 44.21 \\
\hline scenario 2050 & 41.63 & 37.38 & 37.75 & 44.53 & 40.90 & 40.50 & 43.92 & 40.40 & 39.90 & 48.01 & 43.75 & 43.53 \\
\hline $\begin{array}{l}\text { scenario } 2010+ \\
\text { optimal subsidy }\end{array}$ & 41.25 & 37.55 & 37.76 & 44.80 & 40.91 & 41.07 & 44.77 & 40.03 & 40.04 & 47.54 & 44.42 & 44.34 \\
\hline $\begin{array}{l}\text { scenario } 2050+ \\
\text { optimal subsidy }\end{array}$ & 41.58 & 37.33 & 37.71 & 44.46 & 40.84 & 40.44 & 43.87 & 40.35 & 39.85 & 47.96 & 43.70 & 43.49 \\
\hline $\begin{array}{l}\text { scenario } 2010+ \\
\text { subsidy } 5000\end{array}$ & 40.21 & 36.62 & 36.89 & 44.49 & 40.63 & 40.76 & 44.21 & 39.55 & 39.58 & 47.29 & 44.16 & 44.07 \\
\hline $\begin{array}{l}\text { scenario } 2050+ \\
\text { subsidy } 5000\end{array}$ & 41.11 & 36.90 & 37.27 & 44.02 & 40.43 & 40.03 & 43.38 & 39.91 & 39.41 & 47.59 & 43.37 & 43.15 \\
\hline $\begin{array}{l}\text { Mean (over } \\
\text { column) }\end{array}$ & 41.17 & 37.24 & 37.54 & 44.53 & 40.79 & 40.64 & 44.13 & 40.04 & 39.81 & 47.66 & 43.96 & 43.80 \\
\hline
\end{tabular}

* Note: DH- habitual drivers; DL - loss averse drivers; DR - rational drivers

To examine if differences in mean annual emissions between different behavioral models and energy scenarios are statistically significant from each other, we run three OLS regressions with the dependent variable equal to mean total emissions (mean values from 100 simulations) with no constant, and including as independent variables dummies corresponding to different energy scenarios in the first regression; dummies corresponding to different models of car choice in the second regression; and dummies corresponding to different models of driving in the third regression. Subsequently, after each regression, we test if coefficients corresponding to different dummies are significantly different from each other.

We find that there are no statistically significant differences in total $\mathrm{CO}_{2}$ emissions between alternative energy scenarios. This can be explained by the fact that the adoption of electric cars, even in the presence of subsidies for the purchase of electric vehicles, is low, and thus energy scenarios have a 
negligible impact on total emissions (see Section 4.2). On the other hand, there are substantial and statistically significant differences in total emissions between models with rational and habitual drivers (DR and DH models; $F(1,69)=32.40)$. There is no statistically significant difference in total emissions between loss-averse and rational drivers $(\mathrm{F}(1,69)=0.93)$. The former effect can be explained by the higher demand for fuel by habitual agents than by rational agents, as explained above (Figure 3).

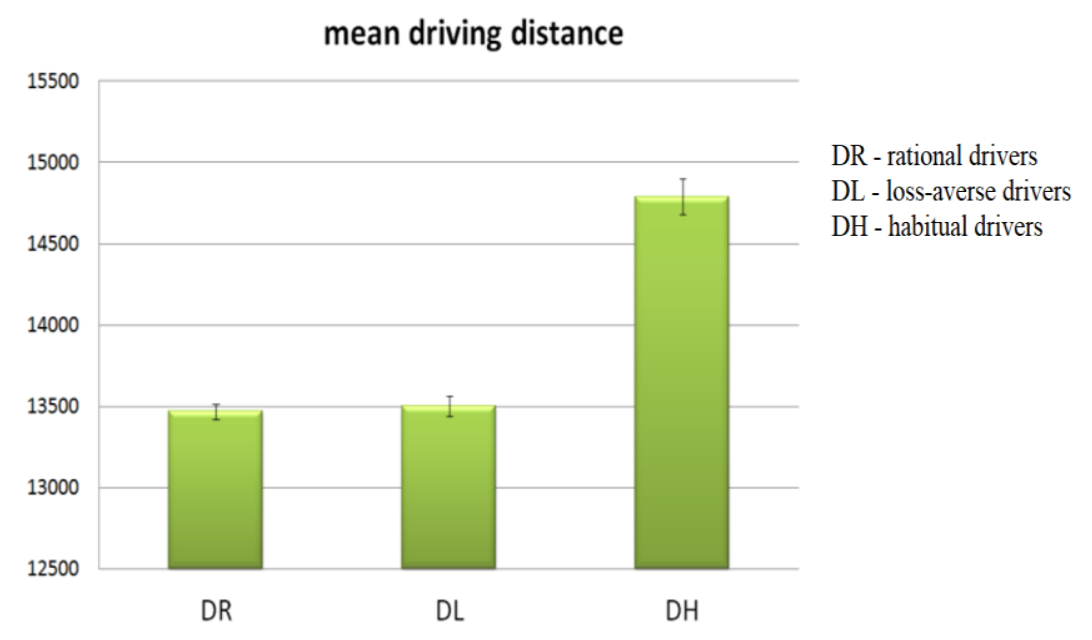

Figure 3. Mean annual distances travelled by the owners of conventional cars in different behavioral models of driving

In addition, we study if there are statistically significant differences in the total emissions from car transport depending on the model of vehicle adoption. The results from regressions support that emissions in the rational model are statistically significantly lower compared to all other behavioral models of vehicle adoption. In particular, the emissions from car transport with fully rational agents are statistically significant lower compared to the model with myopic consumers ( $\mathrm{p}<0.001 ; \mathrm{F}(1,68)=17.29)$; and to the model with loss-oriented consumers $(\mathrm{p}<0.001, \mathrm{~F}(1,68)=26.96)$. Myopic and loss-oriented agents undervalue future energy savings from purchasing more efficient cars, and as a result choose sub-optimal car designs. In turn, the results indicate that the model with habit-oriented consumers (regardless of the type of driving behavior) generate the highest emissions, statistically significantly larger compared to the model with rational consumers $(\mathrm{p}<0.001,(\mathrm{~F}, 1,68)=101.98)$. This is because habitual consumers purchase the least fuel efficient cars, as their choice is less sensitive to technical parameters of different vehicle designs (their price and fuel efficiency), and more to brand considerations. 


\subsection{The diffusion of electric cars}

Table 4 summarizes the rate of adoption of electric cars depending on the subsidy for their purchase, the behavioral model of vehicle adoption, and energy mix in electricity generation. The results in the table indicate that our model generates a realistic adoption rate of electric cars equal to $1 \%$ in the 2010 energy scenario in the absence of subsidies for car purchase. The rate of adoption of electric vehicles increases here up to $6 \%$, if agents are fully rational and receive $€ 5000^{16}$ subsidy. In turn, in the 2050 scenario, a high price of electricity due to a rapid diffusion of renewable energy in the electricity production causes the $€$ 5000 subsidy to be ineffective in stimulating the diffusion of electric cars. This can be explained by the fact that the price of electricity is about three times higher in the 2050 energy scenario compared to the 2010 energy scenario (see Appendix C for more details). Simultaneously, the unit emissions from the electricity sector felt from $0.16 \mathrm{~kg}$ of $\mathrm{CO} 2$ per $\mathrm{kWh}$ in the 2010 scenario to $0.05 \mathrm{~kg}$ of $\mathrm{CO} 2$ per $\mathrm{kWh}$ in the 2050 scenario.

Figure 4(a) illustrates the percentage difference between the rate of adoption of electric cars in distinct behavioral models compared to the rate of adoption of electric cars by rational consumers in the absence of subsidy and under 2010 scenario. The figure illustrate that consumers react differently to subsidies depending on the behavioral model of vehicle adoption. In general, the subsidy is the most effective in the model with habit-oriented consumers compared to other behavioral models, regardless of the type of energy and subsidy scenario. This is because many established brands introduce electric variants of their popular vehicle designs, which increases the chance of them being adopted by consumers. In our model, habit-oriented consumers are the most sensitive to brand considerations.

Moreover, our analysis indicates that the optimal subsidy does not affect the adoption rate of electric cars significantly, yet generates a very high cost for public finance (Figure 4(b)). This is because the optimal subsidy is insufficient to alter decisions of consumers. According to our estimates, the optimal subsidy equals to $€ 625$ under the 2010 energy mix, and to $€ 721$ in the 2050 scenario. As electricity become less emission-intensive, the difference in marginal damages between driving the conventional and electric vehicles increases, translating into a higher subsidy. The value of subsidy is also sensitive to the value of social cost of carbon. We use $P_{s c c}$ equal to $€ 45$ per ton of $\mathrm{CO}_{2}\left(0.045 € / \mathrm{kg}\right.$ of $\mathrm{CO}_{2}$ emissions $)$ in our calculations (CE Delft, 2010). This is similar to the SCC value of $\$ 40$ per ton of $\mathrm{CO}_{2}$ used by Holland et al (2016). They find that the second-best electric vehicle purchase subsidy ranges from $\$ 2785$ in California

16 "Germany considers \$5,500 incentive for electric cars". Reuters. Automotive News Europe. online 201601-29. Accessed at: http://www.reuters.com/article/autos-electric-incentives/germany-considers-5500incentive-for-electric-cars-idUSL8N15D2MM 
to - $\$ 4964$ in North Dakota, depending on the local energy mix in electricity production. It should be noted that the exact value of the SCC has been debated (Pindyck, 2013). Our study indicates that low values of the SCC may result in policies that are ineffective in terms of increasing significantly the adoption rate of electric cars and reducing carbon emissions, yet which are costly to implement. We run additional simulations with the $P_{s c c}$ equal to $€ 125$ per ton of $\mathrm{CO}_{2}$, based on a recent meta-estimate of a lower bound to the SCC (van den Bergh and Botzen, 2014). The results from these additional simulation runs are included in Table 4 and Figures 4(a) and (b). Increasing the price of carbon from $€ 45$ to $€ 125$ raises the mean value of the subsidy from $€ 625$ to $€ 1737$ in the 2010 energy scenario and from $€ 721$ to $€ 2002$ in the 2050 energy scenario. In turn, the adoption rate of electric vehicles increases slightly by $0.3 \%$ between the scenarios with the optimal subsidy equal to $€ 45$ and $€ 125$, at an additional cost of $€ 33$ million for public finance (Figure 4(b)).

Table 4. The mean share of adoption of electric cars- means from 100 simulations

\begin{tabular}{|l|c|c|c|c|}
\hline Model of vehicle adoption & $\begin{array}{l}\text { Rational } \\
\text { model } \\
\text { (AR) }\end{array}$ & $\begin{array}{l}\text { Loss-averse } \\
\text { agents } \\
\text { (AL) }\end{array}$ & $\begin{array}{l}\text { Myopic } \\
\text { agents } \\
\text { (AM) }\end{array}$ & $\begin{array}{l}\text { Habitual } \\
\text { consumers } \\
(\mathrm{AH})\end{array}$ \\
\hline scenario 2010 & 0,025 & 0,017 & 0,024 & 0,033 \\
\hline scenario 2050 & 0,013 & 0,019 & 0,018 & 0,035 \\
\hline $\begin{array}{l}\text { scenario 2010 + optimal subsidy } \\
\mathrm{P}_{\text {scc }}=\text { } 45\end{array}$ & 0,028 & 0,018 & 0,025 & 0,033 \\
\hline $\begin{array}{l}\text { scenario 2050 + optimal subsidy } \\
\mathrm{P}_{\text {scc }}=€ 45\end{array}$ & 0,014 & 0,020 & 0,019 & 0,036 \\
\hline $\begin{array}{l}\text { scenario 2010 + optimal subsidy } \\
\mathrm{P}_{\text {scc }}=€ 125\end{array}$ & 0,032 & 0,021 & 0,028 & 0,035 \\
\hline $\begin{array}{l}\text { scenario 2050 + optimal subsidy } \\
\mathrm{P}_{\text {scc }}=€ 125\end{array}$ & 0,017 & 0,024 & 0,022 & 0,038 \\
\hline scenario 2010+ subsidy 5000 & 0,061 & 0,028 & 0,041 & 0,041 \\
\hline scenario 2050 + subsidy 5000 & 0,026 & 0,031 & 0,030 & 0,044 \\
\hline
\end{tabular}




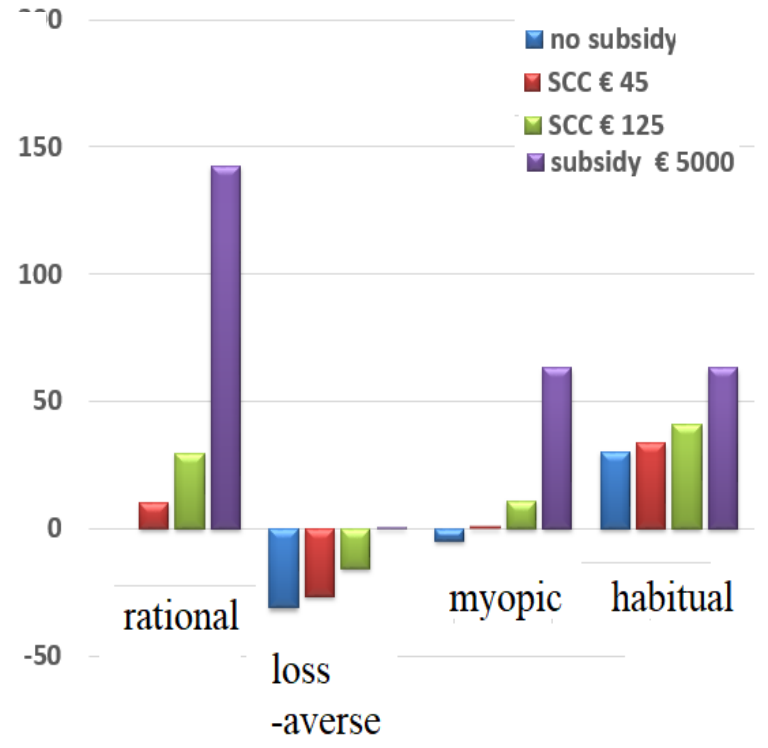

2010 scenario

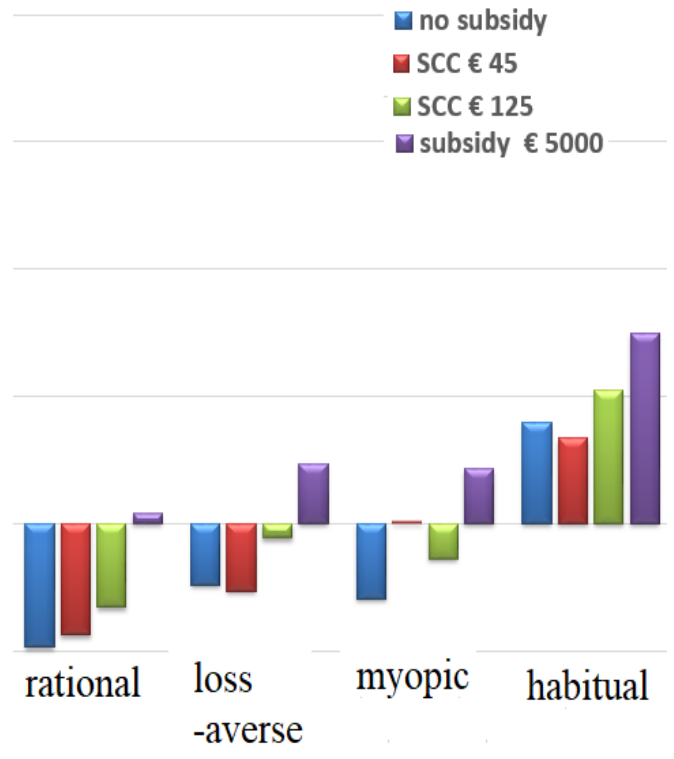

2050 scenario

Figure 4(a). The percentage difference between the rate of adoption of electric cars in different behavioral model of vehicle adoption compared to the rational model in 2010 scenario
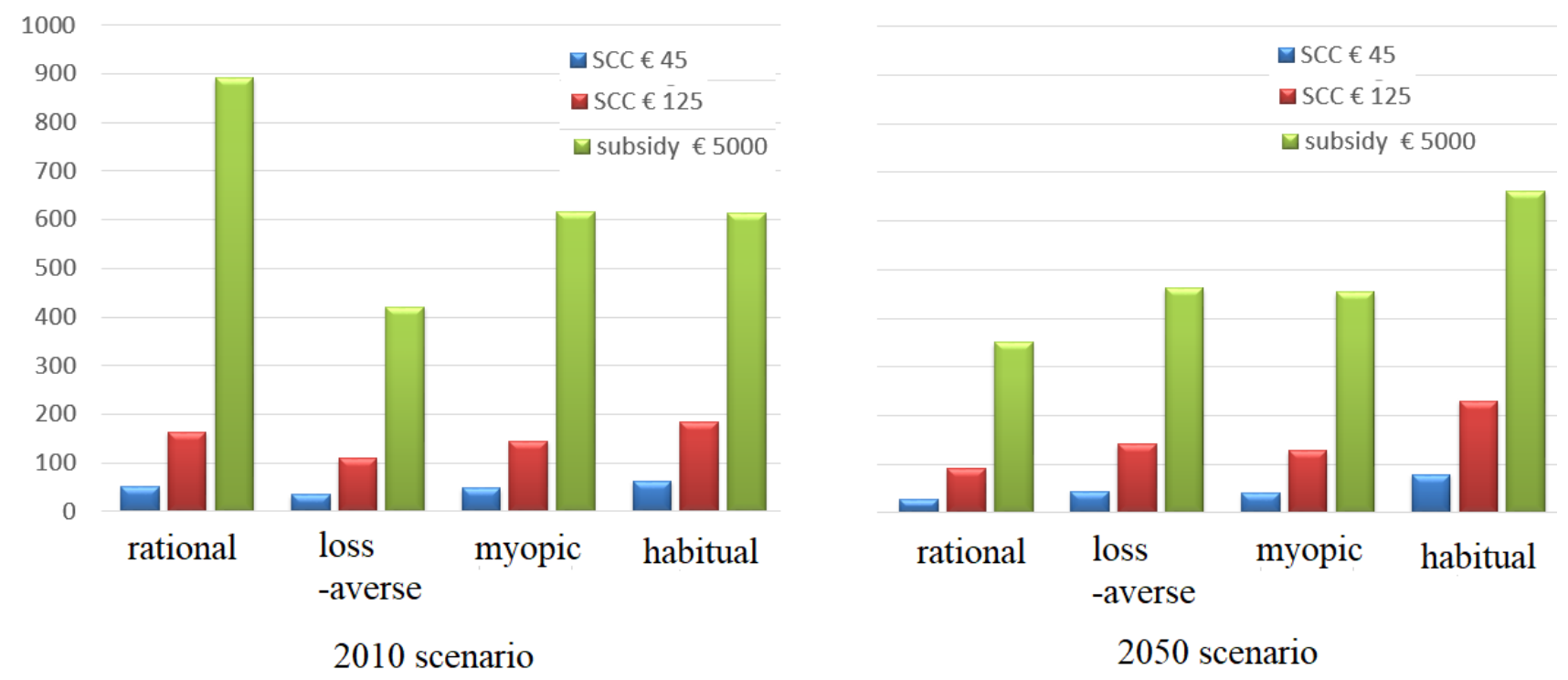

Figure 4(b) The cost of subsidies [€ million] 


\subsection{The rebound effects under different behavioral models}

Interest has risen in recent years about the impact of bounded rationality on energy savings (e.g. Gillingham et al., 2009). It has been long recognised that policy measures, implemented with the aim of encouraging energy savings in production and consumption, can generate results opposite to those expected. This phenomenon is known as the rebound effect (e.g. Brookers, 2000; Sorrel, 2007). The effect goes back to Jevons (1865), who suggests that improvements in the efficiency of coal-fired steam engines would result in more coal consumption, ultimately offsetting the benefits from increased efficiency. Depending on the study, the precise estimates regarding the rebound effect in the automobile sector range from 0 to 89 percent. However, current estimates are closer to 10-30\% (US EPA, 2011).

Typically, the rebound effect in relation to car use is the intensity effect, measured as the negative of the elasticity of driving with respect to fuel cost per unit distance, also referred to as the price-elasticity of vehicle miles of travel (VMT) (see Greene, 1992; Graham and Glaister, 2004; Brons et al., 2008). Thus, two factors have an impact on the magnitude of the rebound effect: improvements in fuel efficiencies and changes in fuel prices. To account for this, Small and Van Dender (2007) examine the magnitude of the rebound effect in a model, where VMT, vehicle ownership, and fuel efficiency are simultaneously determined. The authors find that the rebound effect increases with fuel cost. Similarly, the findings from Hymel and Small (2014) study indicate that the rebound effect is much greater in magnitude in years when gasoline prices are rising than when they are falling. Although a topic for a separate study, rebound might also be assessed by including the embodied energy of cars (in production). The reason is that it possibly differs considerably among types of cars, including on average between gasoline and electric vehicles.

In this paper, we take a different approach and we examine the impact of different types of bounded rationality on the rebound effect. As our model accounts for the changes in fuel prices, which evolve according to the random walk, and improvements in fuel efficiencies of different car designs, which are determined exogenously by car manufacturers, it allows for a detailed analysis of how different types of behavioural models influence the probability of the rebound effect. Table 5(a) presents results from 8 panel regression models using our simulation data. We pooled data from 20 simulations for each of 12 behavioural models. ${ }^{17}$ The depended variable in Models 1-4 is the logarithm of mean distance travelled by owners of diesel cars at time $t$; while in Models 5-8, the dependent variable is the logarithm of mean distance travelled by owners of petrol cars at time $t$. As independent variables, we added the log of mean fuel economy of petrol cars at time $t$ on the market and the logarithm of price of petrol in Models 5-8; and the log of mean fuel economy of diesel cars at time $t$ on the market and the logarithm of price of diesel fuel in Models 1-4. As fuel economy FC is expressed in our model in terms of $\mathrm{L} / 100 \mathrm{~km}$, we converted this measure into

\footnotetext{
${ }^{17}$ We pooled results from 20 instead of 1 simulations for each model, because of the presence of stochastic factors.
} 
2000/FC, so it is expressed as a distance driven per $20 \mathrm{~km}(\mathrm{~km} / 20 \mathrm{~L})$. We conducted the analysis using the pooled data from all scenarios, as well as on a subset of data from specific models of driving behavior (DR, DL, DH) separately. The reported results come from the fixed-effects panel model. This is motivated by the fact that Hausman test indicates that the fixed-effects model is preferable over random-effect regressions (Chi2=144.66 for petrol and Chi2=77.43 for diesel). Moreover, we introduce AR(1) disturbances to control for serial correlation. In particular, the Wooldridge test indicates that our data suffers from this problem ${ }^{18}$.

The results from Table 4(a) indicate that the magnitude of the rebound effect equals to $4 \%$ in case of petrol cars, which is close to the value of $3 \%$ as estimated by Greene (2012) for the U.S. economy between 1967-2009 (Model 5). A different picture emerges from the study of diesel cars. The rebound effect constitutes here 7\% (Model 1). The effect is statistically significant if consumers are rational or loss averse, but not in the model with habit-oriented drivers.

Table 5(a). The probability of the rebound effect; the results from panel regressions with fixed effects and $\mathrm{AR}(1)$ disturbances

\begin{tabular}{|l|c|c|c|c|c|c|c|c|}
\hline $\begin{array}{l}\text { Dependent } \\
\text { variable }\end{array}$ & \multicolumn{4}{|c|}{ Log(distance driven } & \multicolumn{4}{c|}{ Log(distance driven } \\
by owners of diesel cars) & \multicolumn{4}{c|}{ owners of petrol cars) } \\
\hline & Model 1 & Model 2 & Model 3 & Model 4 & Model 5 & Model 6 & Model 7 & Model 8 \\
\hline & Total & Only & Only & Only & Total & Only & Only & Only \\
& sample & DR & DL & DH & sample & DR & DL & DH \\
\hline Log(2000/FC) & $0.07^{* * *}$ & $0.08^{* * *}$ & $0.07 * * *$ & 0.03 & $0.04^{* * *}$ & 0.003 & $0.04^{* * *}$ & 0.02 \\
& $(0.01)$ & $(0.02)$ & $(0.01)$ & $(0.02)$ & $(0.01)$ & $(0.03)$ & $(0.01)$ & $(0.03)$ \\
\hline Log(fuel & $-0.08^{* * *}$ & $-0.05^{* * *}$ & $-0.11^{* * *}$ & $-0.06^{* * *}$ & $-0.08^{* * *}$ & $-0.04 * * *$ & $-0.12^{* * * *}$ & $-0.06^{* * * *}$ \\
price) & $(0.004)$ & $(0.01)$ & $(0.01)$ & $(0.01)$ & $(0.004)$ & $(0.01)$ & $(0.01)$ & $(0.01)$ \\
\hline Constant & $9.16^{* * *}$ & $9.02^{* * *}$ & $9.11^{* * *}$ & 9.43 & $9.35^{* * *}$ & $9.50^{* * *}$ & $9.30^{* * *}$ & $9.52^{* * *}$ \\
& $(0.02)$ & $(0.03)$ & $(0.03)$ & $(0.03)$ & $(0.03)$ & $(0.05)$ & $(0.05)$ & $(0.05)$ \\
\hline N obs & 11520 & 3840 & 3840 & 3840 & 11520 & 3840 & 3840 & 3840 \\
N groups & 240 & 80 & 80 & 80 & 240 & 80 & 80 & 80 \\
\hline R2 within & 0.04 & 0.01 & 0.12 & 0.02 & 0.03 & 0.01 & 0.13 & 0.02 \\
between & 0.03 & 0.23 & 0.37 & 0.43 & 0.02 & 0.39 & 0.39 & 0.34 \\
overall & 0.16 & 0.20 & 0.19 & 0.23 & 0.12 & 0.20 & 0.17 & 0.22 \\
F-statistic & $\mathrm{F}(2,11278)$ & $\mathrm{F}(2,3758)$ & $\mathrm{F}(2,3758)$ & $\mathrm{F}(2,3758)$ & $\mathrm{F}(2,11278)$ & $\mathrm{F}(2,3758)$ & $\mathrm{F}(2,3758)$ & $\mathrm{F}(2,3758)$ \\
& $=207.74$ & $=27.51$ & $=262.95$ & $=38.17$ & $=174.98$ & $=12.52$ & $=292.67$ & $=35.08$ \\
\hline
\end{tabular}

Note: standard deviations in parenthesis; $* * *$ indicates variables significant at the 1 percent level, $* *$ at the 5 percent level, and * at the 10 percent level

Figure 4(b) reports results from panel regressions conducted in an analogous way to estimations reported in Table 5(a), but with additional variables controlling for the model of car choice, i.e. with AH, $\mathrm{AL}$ and $\mathrm{AM}$ dummies. The $\mathrm{AH}, \mathrm{AL}$ and $\mathrm{AM}$ dummies take a value, which is equal to 1 , if shares of car designs were updated according to the model with habitual, loss-averse or myopic consumers, respectively.

18 The results of the Wooldridge test indicate that $\mathrm{F}(1,239)=235.31$ in case of regressions for petrol cars, and $\mathrm{F}(1,239)=237.65$ in case of 'diesel' regressions. 
This is motivated by the fact that fuel economies of newly purchased cars vary between alternative behavioural models. Figures 5(a) and 5(b) illustrate mean FC of petrol and diesel cars over time from 600 mode ${ }^{19}$ depending on the behavioural models of vehicle adoption. The figure illustrates that myopic and loss averse agents adopt less fuel-efficient vehicles than rational agents, as they undervalue expenses on fuel over the vehicle lifetime, with habitual consumers choosing the least fuel-efficient cars. After controlling for car choice in the analysis, we find that the results in Table 5(a) overestimate the rebound effect for rational and loss averse consumers, which drops to 2-5\% after controlling for the car choice. However, in case of the habitual drivers, ignoring car choice leads to the underestimation of the rebound effect. In particular, in the DH model, the rebound effect reaches 14 and 20 percent for owners of diesel and petrol cars, respectively. Interestingly, these values are in line with estimates from Small and van Denter (2007), who estimate the long-run rebound effect to be equal to $22.2 \%$ respectively, after accounting for the choice of fuel efficiencies in their analysis.

Table 5(b). The probability of the rebound effect after controlling for the behavioral model of car choice; the results from panel regressions with fixed effects and AR(1) disturbances

\begin{tabular}{|l|c|c|c|c|c|c|}
\hline $\begin{array}{l}\text { Dependent } \\
\text { variable }\end{array}$ & \multicolumn{3}{|c|}{$\begin{array}{c}\text { Log(distance driven } \\
\text { by owners of diesel cars) }\end{array}$} & \multicolumn{3}{c|}{$\begin{array}{c}\text { Log(distance driven } \\
\text { by owners of petrol cars) }\end{array}$} \\
\hline & Model 1 & Model 2 & Model 3 & Model 4 & Model 5 & Model 6 \\
\hline & Only & Only & Only & Only & Only & Only \\
& DR & DL & DH & DR & DL & DH \\
\hline Log(2000/FC) & $0.03^{* *}$ & $0.05^{* * *}$ & $0.14^{* * *}$ & -0.01 & $0.02^{* *}$ & $0.20^{* * *}$ \\
& $(0.01)$ & $(0.01)$ & $(0.02)$ & $(0.03)$ & $(0.01)$ & $(0.03)$ \\
\hline Log(fuel & $-0.05^{* * *}$ & $-0.08^{* * *}$ & $-0.06^{* * *}$ & $-0.04^{* * *}$ & $-0.08^{* * *}$ & $-0.06^{* * *}$ \\
price) & $(0.01)$ & $(0.004)$ & $(0.01)$ & $(0.01)$ & $(0.003)$ & $(0.01)$ \\
\hline AL & -0.003 & $0.01^{*}$ & 0.01 & -0.002 & $0.01^{*}$ & $0.02^{* * *}$ \\
& $(0.01)$ & $(0.003)$ & $(0.01)$ & $(0.001)$ & $(0.004)$ & $(0.01)$ \\
\hline AM & -0.004 & 0.01 & 0.01 & 0.001 & 0.002 & $0.01 *$ \\
& $(0.01)$ & $(0.003)$ & $(0.01)$ & $(0.01)$ & $(0.003)$ & $(0.01)$ \\
\hline AH & 0.0001 & 0.001 & $0.02^{* *}$ & -0.001 & $0.01 * *$ & $0.03^{* * *}$ \\
& $(0.09)$ & $(0.003)$ & $(0.01)$ & $(0.01)$ & $(0.003)$ & $(0.01)$ \\
\hline Constant & $9.31^{* * *}$ & $9.23^{* * *}$ & $8.72^{* * *}$ & $9.50^{* * *}$ & $9.39^{* * *}$ & $8.44^{* * *}$ \\
& $(0.03)$ & $(0.04)$ & $(0.08)$ & $(0.05)$ & $(0.07)$ & $(0.15)$ \\
\hline N obs & 3920 & 3920 & 3920 & 3920 & 3920 & 3920 \\
N groups & 80 & 80 & 80 & 80 & 80 & 80 \\
\hline R2 within & 0.33 & 0.24 & 0.20 & 0.27 & 0.25 & 0.20 \\
between & 0.28 & 0.38 & 0.45 & 0.39 & 0.42 & 0.42 \\
overall & 0.26 & 0.19 & 0.20 & 0.19 & 0.17 & 0.19 \\
W-statistic & $\mathrm{W}(6)$ & $\mathrm{W}(6)$ & $\mathrm{W}(6)$ & $\mathrm{W}(6)$ & $\mathrm{W}(6)$ & $\mathrm{W}(6)$ \\
& $=56.85$ & $=450.12$ & $=166.98$ & $=36.83$ & $=460.72$ & $=116.36$ \\
\hline
\end{tabular}

Note: standard deviations in parenthesis; *** indicates variables significant at the 1 percent level, $* *$ at the 5 percent level, and * at the 10 percent level

${ }^{19} 100$ simulations were conducted for each of six energy scenarios. 


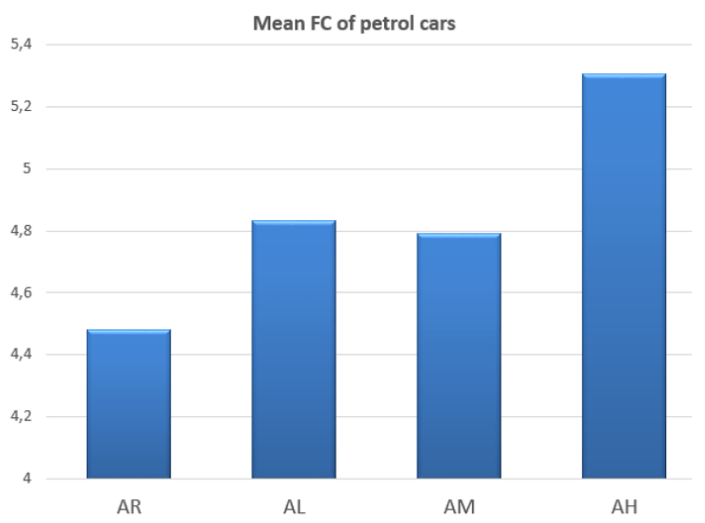

(a) Mean FC of petrol cars on the market

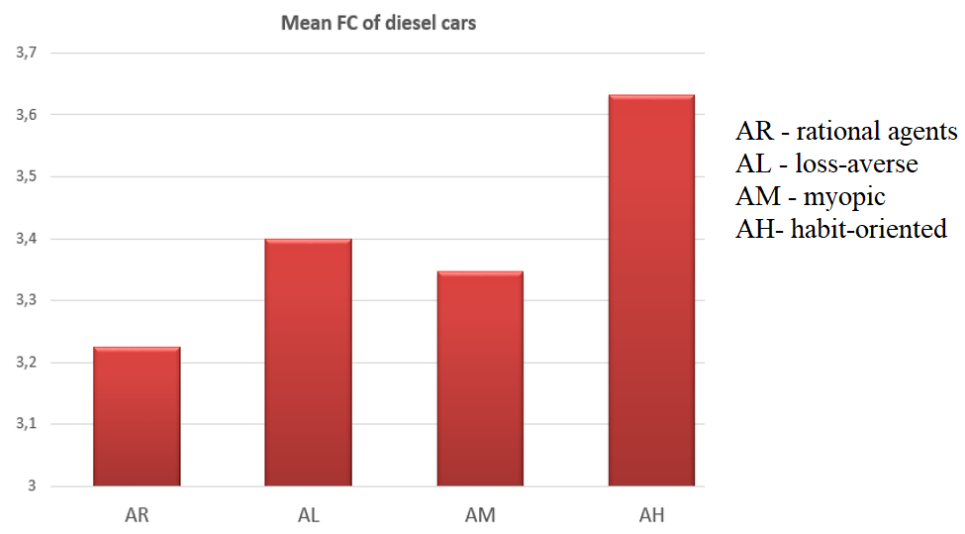

(b) Mean FC of diesel cars on the market

Figure 5. Mean fuel-efficiency of conventional cars in different behavioral models of car adoption

\section{Conclusions}

In this paper, we provide a systematic comparison of how incorporating realistic behaviors of car purchase and driving affects the life-cycle assessment of emissions from electric and conventional cars. The approached used combines four elements: an econometric analysis of fuel economies of new cars in Germany between 2010-2015; a life-cycle analysis of emissions from conventional and electric cars; discrete choice models of vehicle adoption and driving that incorporate realistic behaviors; and modelling of the electricity sector. We adopt this approach to study the rebound effect. In particular, we examine how improvements in fuel efficiency of new cars affect $\mathrm{CO}_{2}$ emissions under different behavioral models.

Current estimates of emissions from car transport are based on the rational model of behavior, ignoring complexities of consumer choices. This is surprising as a variety of behavioral anomalies have been identified in the literature to affect car buying choice and driving behavior. In this context, the question arises how different types of bounded rationality affect decisions in the automobile sector. Addressing it is important for designing effective policies aimed at promoting fuel-efficient and electric cars. Against this background, we provide a systematic comparison of how incorporating different realistic behaviors into the assessment of future emissions from electric and conventional cars will affect their estimates. We consider four behavioral models of car choice (rational, myopic, loss-averse and habitual consumers) in combination with three models of driving (rational, loss-averse and habitual drivers). We show that rational models of vehicle choice and driving generate consistently the lowest estimates of future emissions from car transport. This suggests that ignoring realistic behaviors in the analysis may underestimate future emissions. In 
addition, we find that the probability of the rebound effect varies between different behavioral models of car choice and driving, with the probability of the rebound effect being the highest if drivers are habitual. In general, habit-oriented drivers do not react optimally to changes in fuel prices, commuting on average larger distances and generating higher emissions than rational consumers. On the other hand, myopic and loss-averse individuals buy less fuel-efficient cars, compared to the rational consumers, which also increases emissions from car transport.

Our study is also motivated by the fact that the emission reduction from the electrification of car transport depends on the energy mix in electricity production. There are concerns that the transition in the electricity sector will drive the price of electricity up, which may undermine the diffusion of electric cars. In this context, we study how different policies aimed at promoting renewable energy affect the price of electricity, and the adoption of electric vehicles. In our model, technological change on the electricity market occurs through the installation of power plants embodying different energy technologies. We find that replacing fossil fuels in electricity generation by renewable energy by 2050 may triple the electricity price, undermining the positive effect of subsidies on the adoption of electric cars. The effectiveness of subsidies moreover varies between different behavioral models of car choice. All in all, our study suggests that incorporating realistic behaviors into policy analysis is important as it generates distinct and more accurate policy prescriptions than assuming rational consumers and drivers. It opens venues for future empirical analysis so as to examine the strength of different behavioral anomalies in car mobility.

\section{Acknowledgments}

The research was supported by the National Science Centre, Poland, grant 2016/21/B/HS4/00647.

\section{References}

Allaz, B., 1992. Oligopoly, uncertainty and strategic forward transactions. International Journal of Industrial Organization 10: 297-308.

Allaz, B., Vila J.-L., 1993. Cournot competition, forward markets and efficiency. Journal of Economic Theory 59: 116.

Allcott, H., Mullainathan, S., Taubinsky, D. 2014. Energy policy with externalities and internalities. Journal of Public Economics 112: 72-88.

Allcott, h., Wozny, N., 2014. Gasoline prices, fuel economy, and the energy paradox. The Review of Economics and Statistics 96: 779-795.

Atkeson, A., Kehoe, P.J., 2007. Modeling the transition to a new economy: lessons from two technological revolutions. American Economic Review 97: 64-88.

Barberis, N., Huang, M., 2001 "Mental Accounting, Loss Aversion, and Individual Stock Returns,"

Bentzen, J. 2004. Estimating the rebound effect in US manufacturing energy consumption. Energy Economics 26: 123-134.

Berry, S.T., 1994. Estimating discrete-choice models of product differentiation. The RAND Journal of Economics 25 : 242-262.

Brandt, M.W., Kinlay, J., 2008. Estimating historical volatility. www.investment-analytics.com.

Brons, M., Nijkamp, P., Pels, E., Rietveld, P., 2008. A meta analysis of the price elasticity of gasoline demand. A SUR approach. Energy Economics 30: 2105-2122. 
Brookes, L., 2000. Energy efficiency fallacies revisited. Energy Policy 28: 355-366

Busse M.R., Knittel, C.R., Zettelmeyer, F., 2013. Are consumers myopic? Evidence from new and used car purchases. American Economic Review 103: 220-256.

Carroll, C. D., Overland, J.R., Weil, D.N., 2000. Saving and growth with habit formation. American Economic Review 90: $341-355$.

CE Delft (2010) Shadow Prices Handbook: Valuation and weighting of emissions and environmental impacts.

Dimitropoulos, A., Oueslati, W., Sintek, C., 2016. The rebound effect in road transport: a meta-analysis of empirical studies. OECD Environmental Working Papers no 113.

Eising, J.W., van Onna, T., Alkemade, F., 2014. Towards smart grids: indentifying the risks that arise from the integration of energy and transport supply chains. Applied Energy 123: 448-455.

EPA (US Environmental Protection Agency) and DOT (US Department of Transportation). 2011. Draft Joint Technical Support Document: Proposed Rulemaking for 2017-2025 Light-Duty Vehicle Greenhouse Gas Emission Standards and Corporate Average Fuel Economy Standards. EPA-420-D-11-901. Washington, DC: EPA and DOT.

EPRS, 2015 Reducing CO2 from transport. European Parliamentary Research Service PE 569.031.

EU, 2013. EU Energy, transport and GHG emissions trends to 2050. Reference Scenario 2013.

Frondel, M., Vance, C., Re-indetyfying the rebound: what about asymmetry? The Energy Journal 34.

FSO (2017). Prices. Data on energy price trends. DW STATIS. Federal Statistical Office.

Garcia-Sierra, M., van den Bergh, J., Mirralles-Guasch, C., 2015. Behavioral economics, travel behavior and environmental-transport policy. Transportation research Part D: Transport and Environment 41: 288-305.

Gillingham, K., Newell, R. Palmer, K. 2009. Energy efficiency economics and policy. Annual Review of Resource Economics 1:597-619.

Gossling, S., Metzler, D., 2017. Germany's climate policy: facing an automobile dilemma. Energy Policy 105: 418428.

Graham, D.J., Glaister, S., 2004. Road traffic demand elasticity estimates: a review. Transport Reviews 23: 261-274.

Greene, D. 2012. Rebound 2007: Analysis of National Light-Duty Vehicle Travel Statistics. Energy Policy 41: 14-28.

Greene, D.L. 1992. Vehicle use and fuel economy: how big is the "rebound" effect? The energy Journal 13: 117-144.

Hoen. A., Geurs, K.T., 2011. The influence of positionality in car-purchasing behavior on the downsizing of new cars. Transportaion research. Part D: Transport and environment 5: 402-308.

Holland, S.P., Mansur, E.T., Muller, N.Z., Yates, A.J. 2016. Are there environmental benefits from driving electric vehicles? The Importance of Local Factors. American Economic Review, 106(12): 3700-3729.

Hymel and Small 2014 The rebound effect for Automobile travel: asymmetric response to price changes and novel features of the 2000s. Mimeo.

IEA (2010). Energy Technology Perspectives. Scenarios and Strategies to 2050. International Energy Agency.

Jensen, S.G., Skytte, K., 2002. Interactions between the power and green certificate markets. Energy Policy 30: 425435.

Jevons, S., 1865. The coal question - can Britain survive? First published in 1865, reprinted by Macmillan in 1906.

Kahn, J. 1986. Gasoline prices and the used automobile market: a rational expectations asset price approach Quarterly Journal of Economics 101(2): 323-340.

Kahnema, D., Lovalo, D., 1993. Time choices and bold forecast: a cognitive perspective on risk taking. Management Science 39: 17-31.

Kahneman, D., Tversky, A., (1979). Prospect theory: an analysis of decision under risk. Econometrica 47: 263-291.

Kalinowska, D., Kuhfeld, H., 2006. Motor vehicle use and travel behavior in Germany: determinants of car millage. DIW working paper DP602.

Kasten, P., Bracken, J., Haller, M., 2016. Electric mobility in Europe - Future impact on the emissions and the energy systems. Final Report Oko-Institiute e.V.

Kilian, L., Sims, E., 2006. The effects of real gasoline prices on automobile demand: a structural analysis using micro data. Mimeo.

Kost, C., Mayers, J.N., Thomse, J., Haartmann, N., Senkpeil, C., Philipps, S., Nold, S., Lude, S., Saad, N., Schlegl, T., 2013. Levelized cost of electrity renewable energy technologies. Study. Fraunhofer ISE.

Ligterink, N.E., Smokers, R.T.M., Spreen, J., Mock, P., Tietge, U., 2016. Supporting analysis on real-world light-duty vehicle C02 emissions. TNO report R10419v3.

Linn, J., 2013. The rebound effect for passenger vehicles. Resources for the future discussion paper.

Michalek, J., M. Chester, P. Jaramillo, C. Samaras, C. Shiau, and L. Lave (2011) Valuation of plug-in vehicle lifecycle air emissions and oil displacement benefits. PNAS 108: 16554-16558.

Miotti et al., 2016; 
Moreno, B., Lopez, A.J., Garcia-Alvarez, M.T., 2012. The electricity prices in the European Union. The role of renewable energies and regulatory electric market reforms. Energy 48: 307-313.

Nerlove, M., 1963. Returns to scale in electricity supply. In Christ, C.F., Friedmand, M., Goodman, L.A., Girliches, Z., Harberger, A.C., Liviatian, N., Mincer, J., Mundlak, Y., Nerlove, M., Patinkin, D., Telser, L., Theil, H. (Editors) Measurements in economics: Studies in mathematical economics and econometrics in memory of Yehuda Grunfeld. Stanford University Press, Standford CA, pp. 167-198.

Pindyck, R.S., 2013. Climate change policy: what do models tell us? Journal of Economic Literature 51: 860-872.

Rasouli S. Timmermans H.J.P. 2016. Specification of regret-based models of choice behavior: Formal analyses and experimental design based evidence. Transportation: 1-12.

Safarzynska, K., 2012. Modeling the rebound effect in two manufacturing industries. Technological Forecasting and Social Change 79: 1135-1154.

Safarzynska, K., van den Bergh, J., 2017. Financial instability due to investing rapidly in renewable energy. Energy Policy. 108: 12-20.

Safarzynska K., van den Bergh, J., 2011. Industry evolution, rationality, and electricity transitions. Energy Policy 39: 6440-6452.

Sallee, J.M., West, S.E/. Fan, W., 2009. Consumer valuation of fuel economy: A microdata approach. Discussion paper, National Tax Association Conference Proceedings.

Benartzi, S. Thaler, R., 1995. Myopic Loss Aversion and the Equity Premium Puzzle. Quarterly Journal of Economics: 73-92.

Small, K., and K. van Dender. 2007. Fuel Efficiency in Motor Vehicle Travel: The Declining Rebound Effect. The Energy Journal 28(1): 25-51.

Sorrell, S., 2009. Jevons' Paradox revised: the evidence for backfire from improved energy efficiency. Energy Policy 37: 1456-1469.

Thaler, R.H., 1999. Mental accounting matters. Journal of Behavioral Decision Making 12: 183-206.

van den Bergh, J., Botzen, W., 2014. A lower bound to the social cost of $\mathrm{CO}_{2}$ emissions. Nature Climate Change 4: 253-258.

van den Bergh, J., Botzen, W., 2015. Monetary valuation of the social cost of $\mathrm{CO}_{2}$ emissions: a critical survey. Ecological Economics 114:33-46.

Yuksel, T., Michalek, J., 2015. Effects of regional temperature on electric vehicle efficiency, range, and emissions in the United States. Environmental Science and Technology 49: 3974-3980.

\section{Appendix A}

Table A1. The probability of each fuel to be embodied in a newly installed power plants

\begin{tabular}{|l|c|c|}
\hline type of fuel & the baseline scenario & the 2050 scenario \\
\hline coal & 0.4 & 0.75 \\
\hline gas & 0.1025 & 0.055 \\
\hline nuclear & 0.275 & 0 \\
\hline biomass & 0.21 & 0.5 \\
\hline wind & 0.025 & 0.25 \\
\hline solar & 0.01 & 0.12 \\
\hline
\end{tabular}




\section{Appendix B}

Table B.1. Scenario 2010, mean values over time from 100 simulations with different initial seeds

\begin{tabular}{|c|c|c|c|c|c|c|c|c|c|c|c|c|}
\hline & $\begin{array}{l}\mathrm{AR}_{-} \\
\mathrm{DH}\end{array}$ & $\begin{array}{l}\mathrm{AR}_{-} \\
\mathrm{DL}\end{array}$ & $\begin{array}{l}\mathrm{AR}_{-} \\
\mathrm{DR}\end{array}$ & $\begin{array}{l}\mathrm{AL}_{-} \\
\mathrm{AH}\end{array}$ & $\begin{array}{l}\mathrm{AL}_{-} \\
\mathrm{DL}\end{array}$ & $\begin{array}{l}\mathrm{AL}_{-} \\
\mathrm{DR}\end{array}$ & $\begin{array}{l}\mathrm{AM}_{-} \\
\mathrm{DH}\end{array}$ & $\begin{array}{l}\mathrm{AM}_{-} \\
\mathrm{DL}\end{array}$ & $\begin{array}{l}\mathrm{AM}_{-} \\
\mathrm{DR}\end{array}$ & $\begin{array}{l}\mathrm{AH}_{-} \\
\mathrm{DH}\end{array}$ & $\begin{array}{l}\mathrm{AH}_{-} \\
\mathrm{DL}\end{array}$ & $\begin{array}{l}\mathrm{AH}_{-} \\
\mathrm{DR}\end{array}$ \\
\hline share of coal & $\begin{array}{l}0,4 \\
(0,08)\end{array}$ & $\begin{array}{l}0,39 \\
(0,09) \\
\end{array}$ & $\begin{array}{l}0,4 \\
(0,07)\end{array}$ & $\begin{array}{l}0,4 \\
(0,08)\end{array}$ & $\begin{array}{l}0,41 \\
(0,07)\end{array}$ & $\begin{array}{l}0,38 \\
(0,07) \\
\end{array}$ & $\begin{array}{l}0,39 \\
(0,07)\end{array}$ & $\begin{array}{l}0,39 \\
(0,09) \\
\end{array}$ & $\begin{array}{l}0,4 \\
(0,09) \\
\end{array}$ & $\begin{array}{l}0,38 \\
(0,07) \\
\end{array}$ & $\begin{array}{l}0,39 \\
(0,07) \\
\end{array}$ & $\begin{array}{l}0,39 \\
(0,07) \\
\end{array}$ \\
\hline $\begin{array}{l}\text { share of } \\
\text { nuclear }\end{array}$ & $\begin{array}{l}0,52 \\
(0,08)\end{array}$ & $\begin{array}{l}0,52 \\
(0,08)\end{array}$ & $\begin{array}{l}0,52 \\
(0,07)\end{array}$ & $\begin{array}{l}0,51 \\
(0,09)\end{array}$ & $\begin{array}{l}0,51 \\
(0,07)\end{array}$ & $\begin{array}{l}0,52 \\
(0,08)\end{array}$ & $\begin{array}{l}0,54 \\
(0,08)\end{array}$ & $\begin{array}{l}0,51 \\
(0,07)\end{array}$ & $\begin{array}{l}0,51 \\
(0,1)\end{array}$ & $\begin{array}{l}0,52 \\
(0,07)\end{array}$ & $\begin{array}{l}0,53 \\
(0,08)\end{array}$ & $\begin{array}{l}0,51 \\
(0,08)\end{array}$ \\
\hline share of gas & $\begin{array}{l}0,08 \\
(0,05)\end{array}$ & $\begin{array}{l}0,09 \\
(0,05)\end{array}$ & $\begin{array}{l}0,08 \\
(0,05)\end{array}$ & $\begin{array}{l}0,1 \\
(0,06)\end{array}$ & $\begin{array}{l}0,08 \\
(0,04)\end{array}$ & $\begin{array}{l}0,1 \\
(0,05)\end{array}$ & $\begin{array}{l}0,07 \\
(0,05)\end{array}$ & $\begin{array}{l}0,1 \\
(0,06)\end{array}$ & $\begin{array}{l}0,09 \\
(0,05)\end{array}$ & $\begin{array}{l}0,1 \\
(0,04)\end{array}$ & $\begin{array}{l}0,09 \\
(0,05)\end{array}$ & $\begin{array}{l}0,09 \\
(0,05)\end{array}$ \\
\hline $\begin{array}{l}\text { share of } \\
\text { biomass }\end{array}$ & $0(0)$ & $0(0)$ & $0(0)$ & $0(0)$ & $0(0)$ & $0(0)$ & $0(0)$ & $0(0)$ & $0(0)$ & $0(0)$ & $0(0)$ & $0(0)$ \\
\hline $\begin{array}{l}\text { share of } \\
\text { wind }\end{array}$ & $0(0)$ & $0(0)$ & $0(0)$ & $0(0)$ & $0(0)$ & $0(0)$ & $0(0)$ & $0(0)$ & $0(0)$ & $0(0)$ & $0(0)$ & $0(0)$ \\
\hline $\begin{array}{l}\text { share of } \\
\text { solar }\end{array}$ & $0(0)$ & $0(0)$ & $0(0)$ & $0(0)$ & $0(0)$ & $0(0)$ & $0(0)$ & $0(0)$ & $0(0)$ & $0(0)$ & $0(0)$ & $0(0)$ \\
\hline $\begin{array}{l}\text { unit } \\
\text { emissions } \\
{[\mathrm{kg}} \\
\mathrm{CO} 2 / \mathrm{kWh}]\end{array}$ & $\begin{array}{l}0,16 \\
(0,03)\end{array}$ & $\begin{array}{l}0,16 \\
(0,03)\end{array}$ & $\begin{array}{l}0,16 \\
(0,02)\end{array}$ & $\begin{array}{l}0,16 \\
(0,03)\end{array}$ & $\begin{array}{l}0,16 \\
(0,02)\end{array}$ & $\begin{array}{l}0,15 \\
(0,02)\end{array}$ & $\begin{array}{l}0,15 \\
(0,03)\end{array}$ & $\begin{array}{l}0,16 \\
(0,02)\end{array}$ & $\begin{array}{l}0,16 \\
(0,03)\end{array}$ & $\begin{array}{l}0,15 \\
(0,02)\end{array}$ & $\begin{array}{l}0,15 \\
(0,03)\end{array}$ & $\begin{array}{l}0,16 \\
(0,02)\end{array}$ \\
\hline $\begin{array}{l}\text { annual } \\
\text { installation } \\
\text { cost [thous.] }\end{array}$ & $\begin{array}{l}97.33 \\
(55.4)\end{array}$ & $\begin{array}{l}95.02 \\
(51.7)\end{array}$ & $\begin{array}{l}93.13 \\
(57.0)\end{array}$ & $\begin{array}{l}84.265 \\
(53.1)\end{array}$ & $\begin{array}{l}100.32 \\
(62.5)\end{array}$ & $\begin{array}{l}80.28 \\
(58.6)\end{array}$ & $\begin{array}{l}85.72 \\
(60.6)\end{array}$ & $\begin{array}{l}85.11 \\
(54.9)\end{array}$ & $\begin{array}{l}96.18 \\
(51.9)\end{array}$ & $\begin{array}{l}92.94 \\
(55.3)\end{array}$ & $\begin{array}{l}88.07 \\
(59.2)\end{array}$ & $\begin{array}{l}80.08 \\
(54.4)\end{array}$ \\
\hline $\begin{array}{l}\text { electricity } \\
\text { price }\end{array}$ & $\begin{array}{l}0,17 \\
(0,07)\end{array}$ & $\begin{array}{l}0,16 \\
(0,05)\end{array}$ & $\begin{array}{l}0,16 \\
(0,05)\end{array}$ & $\begin{array}{l}0,18 \\
(0,08)\end{array}$ & $\begin{array}{l}0,17 \\
(0,05)\end{array}$ & $\begin{array}{l}0,19 \\
(0,11)\end{array}$ & $\begin{array}{l}0,16 \\
(0,05)\end{array}$ & $\begin{array}{l}0,17 \\
(0,05)\end{array}$ & $\begin{array}{l}0,18 \\
(0,1)\end{array}$ & $\begin{array}{l}0,2 \\
(0,17)\end{array}$ & $\begin{array}{l}0,19 \\
(0,11)\end{array}$ & $\begin{array}{l}0,17 \\
(0,12)\end{array}$ \\
\hline $\begin{array}{l}\text { gasoline } \\
\text { price }\end{array}$ & $\begin{array}{l}1,69 \\
(0,5)\end{array}$ & $\begin{array}{l}1,65 \\
(0,44)\end{array}$ & $\begin{array}{l}1,6 \\
(0,45)\end{array}$ & $\begin{array}{l}1,69 \\
(0,47)\end{array}$ & $\begin{array}{l}1,72 \\
(0,49)\end{array}$ & $\begin{array}{l}1,78 \\
(0,46)\end{array}$ & $\begin{array}{l}1,61 \\
(0,45)\end{array}$ & $\begin{array}{l}1,64 \\
(0,43)\end{array}$ & $\begin{array}{l}1,71 \\
(0,42)\end{array}$ & $\begin{array}{l}1,69 \\
(0,46)\end{array}$ & $\begin{array}{l}1,75 \\
(0,49)\end{array}$ & $\begin{array}{l}1,77 \\
(0,48)\end{array}$ \\
\hline diesel price & $\begin{array}{l}1,65 \\
(0,46)\end{array}$ & $\begin{array}{l}1,55 \\
(0,45)\end{array}$ & $\begin{array}{l}1,72 \\
(0,48)\end{array}$ & $\begin{array}{l}1,69 \\
(0,5) \\
\end{array}$ & $\begin{array}{l}1,7 \\
(0,48)\end{array}$ & $\begin{array}{l}1,67 \\
(0,5)\end{array}$ & $\begin{array}{l}1,71 \\
(0,51)\end{array}$ & $\begin{array}{l}1,7 \\
(0,49)\end{array}$ & $\begin{array}{l}1,61 \\
(0,48) \\
\end{array}$ & $\begin{array}{l}1,73 \\
(0,45) \\
\end{array}$ & $\begin{array}{l}1,49 \\
(0,39) \\
\end{array}$ & $\begin{array}{l}1,56 \\
(0,42) \\
\end{array}$ \\
\hline $\begin{array}{l}\text { share of } \\
\text { electric cars }\end{array}$ & $\begin{array}{l}0,03 \\
(0,01)\end{array}$ & $\begin{array}{l}0,02 \\
(0,01)\end{array}$ & $\begin{array}{l}0,02 \\
(0,01)\end{array}$ & $\begin{array}{l}0,02 \\
(0)\end{array}$ & $\begin{array}{l}0,02 \\
(0)\end{array}$ & $\begin{array}{l}0,02 \\
(0)\end{array}$ & $\begin{array}{l}0,02 \\
(0)\end{array}$ & $\begin{array}{l}0,02 \\
(0)\end{array}$ & $\begin{array}{l}0,02 \\
(0)\end{array}$ & $\begin{array}{l}0,03 \\
(0)\end{array}$ & $\begin{array}{l}0,03 \\
(0)\end{array}$ & $\begin{array}{l}0,03 \\
(0)\end{array}$ \\
\hline $\begin{array}{l}\text { emissions } \\
\text { [mln tonnes } \\
\text { of CO2] }\end{array}$ & $\begin{array}{l}41,25 \\
(2,16)\end{array}$ & $\begin{array}{l}37,67 \\
(1,46)\end{array}$ & $\begin{array}{l}37,83 \\
(2,21)\end{array}$ & $\begin{array}{l}44,89 \\
(2,4)\end{array}$ & $\begin{array}{l}41,03 \\
(1,52)\end{array}$ & $\begin{array}{l}41,05 \\
(2,02)\end{array}$ & $\begin{array}{l}44,66 \\
(2,2)\end{array}$ & $\begin{array}{l}40,02 \\
(1,52)\end{array}$ & $\begin{array}{l}40,1 \\
(1,74)\end{array}$ & $\begin{array}{l}47,56 \\
(2,25)\end{array}$ & $\begin{array}{l}44,38 \\
(1,45)\end{array}$ & $\begin{array}{l}44,21 \\
(2,04)\end{array}$ \\
\hline $\begin{array}{l}\text { mean FC of } \\
\text { petrol cars }\end{array}$ & $\begin{array}{l}4,48 \\
(0,01)\end{array}$ & $\begin{array}{l}4,48 \\
(0,01)\end{array}$ & $\begin{array}{l}4,48 \\
(0,01)\end{array}$ & $\begin{array}{l}4,85 \\
(0,08)\end{array}$ & $\begin{array}{l}4,83 \\
(0,09)\end{array}$ & $\begin{array}{l}4,82 \\
(0,08) \\
\end{array}$ & $\begin{array}{l}4,79 \\
(0)\end{array}$ & $\begin{array}{l}4,79 \\
(0)\end{array}$ & $\begin{array}{l}4,79 \\
(0)\end{array}$ & $\begin{array}{l}5,31 \\
(0)\end{array}$ & $\begin{array}{l}5,31 \\
(0)\end{array}$ & $\begin{array}{l}5,31 \\
(0)\end{array}$ \\
\hline $\begin{array}{l}\text { mean FC of } \\
\text { diesel cars }\end{array}$ & $\begin{array}{l}3,22 \\
(0,01)\end{array}$ & $\begin{array}{l}3,22 \\
(0,01)\end{array}$ & $\begin{array}{l}3,23 \\
(0,01)\end{array}$ & $\begin{array}{l}3,4 \\
(0,03)\end{array}$ & $\begin{array}{l}3,4 \\
(0,03)\end{array}$ & $\begin{array}{l}3,4 \\
(0,04)\end{array}$ & $\begin{array}{l}3,35 \\
(0)\end{array}$ & $\begin{array}{l}3,35 \\
(0)\end{array}$ & $\begin{array}{l}3,35 \\
(0)\end{array}$ & $\begin{array}{l}3,63 \\
(0)\end{array}$ & $\begin{array}{l}3,63 \\
(0)\end{array}$ & $\begin{array}{l}3,63 \\
(0)\end{array}$ \\
\hline $\begin{array}{l}\text { mean annual } \\
\text { distance by } \\
\text { petrol cars }\end{array}$ & $\begin{array}{l}14936 \\
(910)\end{array}$ & $\begin{array}{l}13631 \\
(533)\end{array}$ & $\begin{array}{l}13345 \\
(973)\end{array}$ & $\begin{array}{l}14647 \\
(1011)\end{array}$ & $\begin{array}{l}13444 \\
(754)\end{array}$ & $\begin{array}{l}13484 \\
(838)\end{array}$ & $\begin{array}{l}14867 \\
(1095)\end{array}$ & $\begin{array}{l}13336 \\
(715)\end{array}$ & $\begin{array}{l}13529 \\
(919)\end{array}$ & $\begin{array}{l}14449 \\
(931)\end{array}$ & $\begin{array}{l}13563 \\
(603)\end{array}$ & $\begin{array}{l}13653 \\
(818)\end{array}$ \\
\hline $\begin{array}{l}\text { mean annual } \\
\text { distance by } \\
\text { diesel cars }\end{array}$ & $\begin{array}{l}14744 \\
(1036)\end{array}$ & $\begin{array}{l}13525 \\
(664)\end{array}$ & $\begin{array}{l}13720 \\
(890)\end{array}$ & $\begin{array}{l}14796 \\
(1023)\end{array}$ & $\begin{array}{l}13569 \\
(645)\end{array}$ & $\begin{array}{l}13577 \\
(874)\end{array}$ & $\begin{array}{l}15002 \\
(966)\end{array}$ & $\begin{array}{l}13433 \\
(629)\end{array}$ & $\begin{array}{l}13369 \\
(716)\end{array}$ & $\begin{array}{l}14638 \\
(1053)\end{array}$ & $\begin{array}{l}13630 \\
(673)\end{array}$ & $\begin{array}{l}13445 \\
(783)\end{array}$ \\
\hline
\end{tabular}


Table B.2. Scenario 2050, mean values over time from 100 simulations with different initial seeds

\begin{tabular}{|c|c|c|c|c|c|c|c|c|c|c|c|c|}
\hline & $\begin{array}{l}\mathrm{AR}_{-} \\
\mathrm{DH}\end{array}$ & $\begin{array}{l}\mathrm{AR}_{-} \\
\mathrm{DL}\end{array}$ & $\begin{array}{l}\mathrm{AR}- \\
\mathrm{DR}\end{array}$ & $\begin{array}{l}\mathrm{AL}_{-} \mathrm{A} \\
\mathrm{H}\end{array}$ & $\begin{array}{l}\text { AL_D } \\
\mathrm{L}\end{array}$ & $\begin{array}{l}\mathrm{AL}{ }_{\mathrm{R}} \mathrm{D} \\
\end{array}$ & $\begin{array}{l}\mathrm{AM}_{-} \\
\mathrm{DH}\end{array}$ & $\begin{array}{l}\mathrm{AM}_{-} \\
\mathrm{DL}\end{array}$ & $\begin{array}{l}\mathrm{AM} \\
\mathrm{DR}\end{array}$ & $\begin{array}{l}\mathrm{AH}_{-} \\
\mathrm{DH}\end{array}$ & $\begin{array}{l}\mathrm{AH}_{-} \\
\mathrm{DL}\end{array}$ & $\begin{array}{l}\mathrm{AH}_{-} \\
\mathrm{DR}\end{array}$ \\
\hline share of coal & $\begin{array}{l}0,1 \\
(0,06)\end{array}$ & $\begin{array}{l}0,12 \\
(0,07)\end{array}$ & $\begin{array}{l}0,12 \\
(0,05)\end{array}$ & $\begin{array}{l}0,1 \\
(0,06)\end{array}$ & $\begin{array}{l}0,1 \\
(0,05)\end{array}$ & $\begin{array}{l}0,12 \\
(0,07)\end{array}$ & $\begin{array}{l}0,12 \\
(0,07)\end{array}$ & $\begin{array}{l}0,11 \\
(0,05)\end{array}$ & $\begin{array}{l}0,11 \\
(0,07)\end{array}$ & $\begin{array}{l}0,11 \\
(0,05)\end{array}$ & $\begin{array}{l}0,11 \\
(0,06)\end{array}$ & $\begin{array}{l}0,1 \\
(0,05)\end{array}$ \\
\hline $\begin{array}{l}\text { share of } \\
\text { nuclear }\end{array}$ & $\begin{array}{l}0,26 \\
(0,02)\end{array}$ & $\begin{array}{l}0,27 \\
(0,02)\end{array}$ & $\begin{array}{l}0,26 \\
(0,02)\end{array}$ & $\begin{array}{l}0,26 \\
(0,02)\end{array}$ & $\begin{array}{l}0,27 \\
(0,02)\end{array}$ & $\begin{array}{l}0,26 \\
(0,02)\end{array}$ & $\begin{array}{l}0,26 \\
(0,02)\end{array}$ & $\begin{array}{l}0,26 \\
(0,02)\end{array}$ & $\begin{array}{l}0,27 \\
(0,02)\end{array}$ & $\begin{array}{l}0,26 \\
(0,02)\end{array}$ & $\begin{array}{l}0,27 \\
(0,02)\end{array}$ & $\begin{array}{l}0,26 \\
(0,02)\end{array}$ \\
\hline share of gas & $\begin{array}{l}0,07 \\
(0,04)\end{array}$ & $\begin{array}{l}0,07 \\
(0,05)\end{array}$ & $\begin{array}{l}0,06 \\
(0,05)\end{array}$ & $\begin{array}{l}0,09 \\
(0,06)\end{array}$ & $\begin{array}{l}0,07 \\
(0,05)\end{array}$ & $\begin{array}{l}0,06 \\
(0,05)\end{array}$ & $\begin{array}{l}0,06 \\
(0,06)\end{array}$ & $\begin{array}{l}0,07 \\
(0,05)\end{array}$ & $\begin{array}{l}0,06 \\
(0,05)\end{array}$ & $\begin{array}{l}0,07 \\
(0,06)\end{array}$ & $\begin{array}{l}0,06 \\
(0,05)\end{array}$ & $\begin{array}{l}0,07 \\
(0,05)\end{array}$ \\
\hline $\begin{array}{l}\text { share of } \\
\text { biomass }\end{array}$ & $\begin{array}{l}0,38 \\
(0,09)\end{array}$ & $\begin{array}{l}0,39 \\
(0,09) \\
\end{array}$ & $\begin{array}{l}0,4 \\
(0,09)\end{array}$ & $\begin{array}{l}0,41 \\
(0,09)\end{array}$ & $\begin{array}{l}0,4 \\
(0,08)\end{array}$ & $\begin{array}{l}0,38 \\
(0,08) \\
\end{array}$ & $\begin{array}{l}0,4 \\
(0,08)\end{array}$ & $\begin{array}{l}0,4 \\
(0,08) \\
\end{array}$ & $\begin{array}{l}0,4 \\
(0,09)\end{array}$ & $\begin{array}{l}0,38 \\
(0,08)\end{array}$ & $\begin{array}{l}0,4 \\
(0,1)\end{array}$ & $\begin{array}{l}0,38 \\
(0,07) \\
\end{array}$ \\
\hline $\begin{array}{l}\text { share of } \\
\text { wind }\end{array}$ & $\begin{array}{l}0,17 \\
(0,07)\end{array}$ & $\begin{array}{l}0,14 \\
(0,07)\end{array}$ & $\begin{array}{l}0,14 \\
(0,07)\end{array}$ & $\begin{array}{l}0,13 \\
(0,07)\end{array}$ & $\begin{array}{l}0,14 \\
(0,08)\end{array}$ & $\begin{array}{l}0,16 \\
(0,08)\end{array}$ & $\begin{array}{l}0,14 \\
(0,08)\end{array}$ & $\begin{array}{l}0,14 \\
(0,07)\end{array}$ & $\begin{array}{l}0,15 \\
(0,08)\end{array}$ & $\begin{array}{l}0,14 \\
(0,06)\end{array}$ & $\begin{array}{l}0,13 \\
(0,08)\end{array}$ & $\begin{array}{l}0,17 \\
(0,07)\end{array}$ \\
\hline $\begin{array}{l}\text { share of } \\
\text { solar }\end{array}$ & $\begin{array}{l}0,02 \\
(0,04)\end{array}$ & $\begin{array}{l}0,02 \\
(0,03)\end{array}$ & $\begin{array}{l}0,02 \\
(0,03)\end{array}$ & $\begin{array}{l}0,02 \\
(0,03)\end{array}$ & $\begin{array}{l}0,02 \\
(0,03)\end{array}$ & $\begin{array}{l}0,02 \\
(0,02)\end{array}$ & $\begin{array}{l}0,02 \\
(0,03)\end{array}$ & $\begin{array}{l}0,02 \\
(0,03)\end{array}$ & $\begin{array}{l}0,01 \\
(0,02)\end{array}$ & $\begin{array}{l}0,02 \\
(0,03)\end{array}$ & $\begin{array}{l}0,03 \\
(0,03)\end{array}$ & $\begin{array}{l}0,02 \\
(0,03)\end{array}$ \\
\hline $\begin{array}{l}\text { unit } \\
\text { emissions } \\
{[\mathrm{kg}} \\
\mathrm{CO} 2 / \mathrm{kWh}]\end{array}$ & $\begin{array}{l}0,05 \\
(0,02) \\
\end{array}$ & $\begin{array}{l}0,05 \\
(0,02) \\
\end{array}$ & $\begin{array}{l}0,05 \\
(0,02) \\
\end{array}$ & $\begin{array}{l}0,05 \\
(0,02) \\
\end{array}$ & $\begin{array}{l}0,05 \\
(0,02) \\
\end{array}$ & $\begin{array}{l}0,05 \\
(0,02) \\
\end{array}$ & $\begin{array}{l}0,05 \\
(0,03) \\
\end{array}$ & $\begin{array}{l}0,05 \\
(0,02) \\
\end{array}$ & $\begin{array}{l}0,05 \\
(0,02) \\
\end{array}$ & $\begin{array}{l}0,05 \\
(0,02) \\
\end{array}$ & $\begin{array}{l}0,05 \\
(0,02) \\
\end{array}$ & $\begin{array}{l}0,05 \\
(0,02) \\
\end{array}$ \\
\hline $\begin{array}{l}\text { annual } \\
\text { installation } \\
\text { cost [thous.] }\end{array}$ & $\begin{array}{l}440.58 \\
(223)\end{array}$ & $\begin{array}{l}383.32 \\
(220)\end{array}$ & $\begin{array}{l}406.72 \\
(227)\end{array}$ & $\begin{array}{l}440.99 \\
(227)\end{array}$ & $\begin{array}{l}392.65 \\
(203)\end{array}$ & $\begin{array}{l}321.82 \\
(2071)\end{array}$ & $\begin{array}{l}379.14 \\
(225)\end{array}$ & $\begin{array}{l}407.34 \\
(236)\end{array}$ & $\begin{array}{l}396.18 \\
(225)\end{array}$ & $\begin{array}{l}402.70 \\
(246)\end{array}$ & $\begin{array}{l}458.75 \\
(232)\end{array}$ & $\begin{array}{l}397.89 \\
(208)\end{array}$ \\
\hline $\begin{array}{l}\text { electricity } \\
\text { price }\end{array}$ & $\begin{array}{l}0,67 \\
(0,28) \\
\end{array}$ & $\begin{array}{l}0,61 \\
(0,26)\end{array}$ & $\begin{array}{l}0,61 \\
(0,27) \\
\end{array}$ & $\begin{array}{l}0,58 \\
(0,22) \\
\end{array}$ & $\begin{array}{l}0,65 \\
(0,27) \\
\end{array}$ & $\begin{array}{l}0,6 \\
(0,28) \\
\end{array}$ & $\begin{array}{l}0,57 \\
(0,26) \\
\end{array}$ & $\begin{array}{l}0,62 \\
(0,29) \\
\end{array}$ & $\begin{array}{l}0,62 \\
(0,27)\end{array}$ & $\begin{array}{l}0,68 \\
(0,29) \\
\end{array}$ & $\begin{array}{l}0,68 \\
(0,28) \\
\end{array}$ & $\begin{array}{l}0,62 \\
(0,24)\end{array}$ \\
\hline $\begin{array}{l}\text { gasoline } \\
\text { price }\end{array}$ & $\begin{array}{l}1,7 \\
(0,43)\end{array}$ & $\begin{array}{l}1,7 \\
(0,52)\end{array}$ & $\begin{array}{l}1,66 \\
(0,48)\end{array}$ & $\begin{array}{l}1,71 \\
(0,47)\end{array}$ & $\begin{array}{l}1,63 \\
(0,4)\end{array}$ & $\begin{array}{l}1,61 \\
(0,45)\end{array}$ & $\begin{array}{l}1,73 \\
(0,51)\end{array}$ & $\begin{array}{l}1,65 \\
(0,55)\end{array}$ & $\begin{array}{l}1,72 \\
(0,48)\end{array}$ & $\begin{array}{l}1,7 \\
(0,46)\end{array}$ & $\begin{array}{l}1,7 \\
(0,43)\end{array}$ & $\begin{array}{l}1,55 \\
(0,38)\end{array}$ \\
\hline diesel price & $\begin{array}{l}1,59 \\
(0,48)\end{array}$ & $\begin{array}{l}1,69 \\
(0,46)\end{array}$ & $\begin{array}{l}1,66 \\
(0,48)\end{array}$ & $\begin{array}{l}1,67 \\
(0,49)\end{array}$ & $\begin{array}{l}1,69 \\
(0,47)\end{array}$ & $\begin{array}{l}1,76 \\
(0,45)\end{array}$ & $\begin{array}{l}1,54 \\
(0,4) \\
\end{array}$ & $\begin{array}{l}1,62 \\
(0,48)\end{array}$ & $\begin{array}{l}1,64 \\
(0,48)\end{array}$ & $\begin{array}{l}1,74 \\
(0,42)\end{array}$ & $\begin{array}{l}1,55 \\
(0,43)\end{array}$ & $\begin{array}{l}1,64 \\
(0,38)\end{array}$ \\
\hline $\begin{array}{l}\text { share of } \\
\text { electric cars }\end{array}$ & $\begin{array}{l}0,01 \\
(0)\end{array}$ & $\begin{array}{l}0,01 \\
(0)\end{array}$ & $\begin{array}{l}0,01 \\
(0)\end{array}$ & $\begin{array}{l}0,02 \\
(0)\end{array}$ & $\begin{array}{l}0,02 \\
(0)\end{array}$ & $\begin{array}{l}0,02 \\
(0)\end{array}$ & $\begin{array}{l}0,02 \\
(0)\end{array}$ & $\begin{array}{l}0,02 \\
(0)\end{array}$ & $\begin{array}{l}0,02 \\
(0)\end{array}$ & $\begin{array}{l}0,03 \\
(0)\end{array}$ & $\begin{array}{l}0,03 \\
(0)\end{array}$ & $\begin{array}{l}0,03 \\
(0)\end{array}$ \\
\hline $\begin{array}{l}\text { emissions } \\
{[\mathrm{mln} \text { tonnes }} \\
\text { of } \mathrm{CO} 2]\end{array}$ & $\begin{array}{l}41,63 \\
(1,94) \\
\end{array}$ & $\begin{array}{l}37,38 \\
(2,08) \\
\end{array}$ & $\begin{array}{l}37,75 \\
(2,04)\end{array}$ & $\begin{array}{l}44,53 \\
(1,86) \\
\end{array}$ & $\begin{array}{l}40,9 \\
(1,55)\end{array}$ & $\begin{array}{l}40,5 \\
(1,94)\end{array}$ & $\begin{array}{l}43,92 \\
(2)\end{array}$ & $\begin{array}{l}40,4 \\
(1,31)\end{array}$ & $\begin{array}{l}39,9 \\
(1,59)\end{array}$ & $\begin{array}{l}48,01 \\
(2,23)\end{array}$ & $\begin{array}{l}43,75 \\
(1,49) \\
\end{array}$ & $\begin{array}{l}43,53 \\
(1,8) \\
\end{array}$ \\
\hline $\begin{array}{l}\text { mean FC of } \\
\text { petrol cars }\end{array}$ & $\begin{array}{l}4,48 \\
(0,01)\end{array}$ & $\begin{array}{l}4,48 \\
(0,01)\end{array}$ & $\begin{array}{l}4,48 \\
(0,01)\end{array}$ & $\begin{array}{l}4,85 \\
(0,08) \\
\end{array}$ & $\begin{array}{l}4,86 \\
(0,08)\end{array}$ & $\begin{array}{l}4,86 \\
(0,08) \\
\end{array}$ & $\begin{array}{l}4,79 \\
(0)\end{array}$ & $\begin{array}{l}4,79 \\
(0)\end{array}$ & $\begin{array}{l}4,79 \\
(0)\end{array}$ & $\begin{array}{l}5,31 \\
(0)\end{array}$ & $\begin{array}{l}5,31 \\
(0)\end{array}$ & $\begin{array}{l}5,31 \\
(0)\end{array}$ \\
\hline $\begin{array}{l}\text { mean FC of } \\
\text { diesel cars }\end{array}$ & $\begin{array}{l}3,22 \\
(0,01)\end{array}$ & $\begin{array}{l}3,22 \\
(0,01)\end{array}$ & $\begin{array}{l}3,22 \\
(0,01)\end{array}$ & $\begin{array}{l}3,4 \\
(0,04)\end{array}$ & $\begin{array}{l}3,4 \\
(0,03)\end{array}$ & $\begin{array}{l}3,39 \\
(0,04)\end{array}$ & $\begin{array}{l}3,35 \\
(0)\end{array}$ & $\begin{array}{l}3,35 \\
(0)\end{array}$ & $\begin{array}{l}3,35 \\
(0)\end{array}$ & $\begin{array}{l}3,63 \\
(0)\end{array}$ & $\begin{array}{l}3,63 \\
(0)\end{array}$ & $\begin{array}{l}3,63 \\
(0)\end{array}$ \\
\hline $\begin{array}{l}\text { mean annual } \\
\text { distance by } \\
\text { petrol cars }\end{array}$ & $\begin{array}{l}15055 \\
(782)\end{array}$ & $\begin{array}{l}13278 \\
(592)\end{array}$ & $\begin{array}{l}13477 \\
(707)\end{array}$ & $\begin{array}{l}14841 \\
(846)\end{array}$ & $\begin{array}{l}13541 \\
(654)\end{array}$ & $\begin{array}{l}13311 \\
(812)\end{array}$ & $\begin{array}{l}14904 \\
(1030)\end{array}$ & $\begin{array}{l}13505 \\
(523)\end{array}$ & $\begin{array}{l}13381 \\
(811)\end{array}$ & $\begin{array}{l}14961 \\
(1035)\end{array}$ & $\begin{array}{l}13515 \\
(734)\end{array}$ & $\begin{array}{l}13381 \\
(815)\end{array}$ \\
\hline $\begin{array}{l}\text { mean annual } \\
\text { distance by } \\
\text { diesel cars }\end{array}$ & $\begin{array}{l}14743 \\
(983)\end{array}$ & $\begin{array}{l}13474 \\
(580)\end{array}$ & $\begin{array}{l}13432 \\
(912,)\end{array}$ & $\begin{array}{l}14607 \\
(784)\end{array}$ & $\begin{array}{l}13449 \\
(644)\end{array}$ & $\begin{array}{l}13396 \\
(872)\end{array}$ & $\begin{array}{l}14566 \\
(722)\end{array}$ & $\begin{array}{l}13530 \\
(633)\end{array}$ & $\begin{array}{l}13341 \\
(799)\end{array}$ & $\begin{array}{l}14794 \\
(909)\end{array}$ & $\begin{array}{l}13548 \\
(634)\end{array}$ & $\begin{array}{l}13549 \\
(869)\end{array}$ \\
\hline
\end{tabular}


Table B.3. Scenario 2010 + optimal subsidy, mean values over time from 100 simulations with different initial seeds

\begin{tabular}{|c|c|c|c|c|c|c|c|c|c|c|c|c|}
\hline & $\begin{array}{l}\mathrm{AR}_{-} \\
\mathrm{DH}\end{array}$ & $\begin{array}{l}\mathrm{AR}- \\
\mathrm{DL}\end{array}$ & $\begin{array}{l}\mathrm{AR}_{-} \\
\mathrm{DR}\end{array}$ & $\begin{array}{l}\mathrm{AL}_{-} \\
\mathrm{AH}\end{array}$ & $\begin{array}{l}\mathrm{AL}_{-} \\
\mathrm{DL}\end{array}$ & $\begin{array}{l}\mathrm{AL}_{-} \\
\mathrm{DR}\end{array}$ & $\begin{array}{l}\mathrm{AM}_{-} \\
\mathrm{DH}\end{array}$ & $\begin{array}{l}\mathrm{AM}_{-} \\
\mathrm{DL}\end{array}$ & $\begin{array}{l}\mathrm{AM}_{-} \\
\mathrm{DR}\end{array}$ & $\begin{array}{l}\mathrm{AH}_{-} \\
\mathrm{DH}\end{array}$ & $\begin{array}{l}\mathrm{AH}_{-} \\
\mathrm{DL}\end{array}$ & $\begin{array}{l}\mathrm{AH}_{-} \\
\mathrm{DR}\end{array}$ \\
\hline share of coal & $\begin{array}{l}0,4 \\
(0,08)\end{array}$ & $\begin{array}{l}0,4 \\
(0,08)\end{array}$ & $\begin{array}{l}0,39 \\
(0,07)\end{array}$ & $\begin{array}{l}0,39 \\
(0,08)\end{array}$ & $\begin{array}{l}0,4 \\
(0,07)\end{array}$ & $\begin{array}{l}0,39 \\
(0,07)\end{array}$ & $\begin{array}{l}0,38 \\
(0,08)\end{array}$ & $\begin{array}{l}0,39 \\
(0,09)\end{array}$ & $\begin{array}{l}0,4 \\
(0,09)\end{array}$ & $\begin{array}{l}0,39 \\
(0,07)\end{array}$ & $\begin{array}{l}0,39 \\
(0,08)\end{array}$ & $\begin{array}{l}0,39 \\
(0,07)\end{array}$ \\
\hline $\begin{array}{l}\text { share of } \\
\text { nuclear }\end{array}$ & $\begin{array}{l}0,52 \\
(0,08)\end{array}$ & $\begin{array}{l}0,52 \\
(0,08)\end{array}$ & $\begin{array}{l}0,52 \\
(0,06)\end{array}$ & $\begin{array}{l}0,51 \\
(0,09)\end{array}$ & $\begin{array}{l}0,52 \\
(0,07)\end{array}$ & $\begin{array}{l}0,51 \\
(0,08)\end{array}$ & $\begin{array}{l}0,54 \\
(0,09)\end{array}$ & $\begin{array}{l}0,51 \\
(0,07)\end{array}$ & $\begin{array}{l}0,51 \\
(0,1)\end{array}$ & $\begin{array}{l}0,52 \\
(0,07)\end{array}$ & $\begin{array}{l}0,53 \\
(0,09)\end{array}$ & $\begin{array}{l}0,52 \\
(0,08)\end{array}$ \\
\hline share of gas & $\begin{array}{l}0,08 \\
(0,04)\end{array}$ & $\begin{array}{l}0,09 \\
(0,05)\end{array}$ & $\begin{array}{l}0,09 \\
(0,05)\end{array}$ & $\begin{array}{l}0,1 \\
(0,06)\end{array}$ & $\begin{array}{l}0,08 \\
(0,04)\end{array}$ & $\begin{array}{l}0,1 \\
(0,05)\end{array}$ & $\begin{array}{l}0,07 \\
(0,05)\end{array}$ & $\begin{array}{l}0,1 \\
(0,06)\end{array}$ & $\begin{array}{l}0,09 \\
(0,04)\end{array}$ & $\begin{array}{l}0,1 \\
(0,04)\end{array}$ & $\begin{array}{l}0,09 \\
(0,05)\end{array}$ & $\begin{array}{l}0,09 \\
(0,04)\end{array}$ \\
\hline $\begin{array}{l}\text { share of } \\
\text { biomass }\end{array}$ & $0(0)$ & $0(0)$ & $0(0)$ & $0(0)$ & $0(0)$ & $0(0)$ & $0(0)$ & $0(0)$ & $0(0)$ & $0(0)$ & $0(0)$ & $0(0)$ \\
\hline $\begin{array}{l}\text { share of } \\
\text { wind }\end{array}$ & $0(0)$ & $0(0)$ & $0(0)$ & $0(0)$ & $0(0)$ & $0(0)$ & $0(0)$ & $0(0)$ & $0(0)$ & $0(0)$ & $0(0)$ & $0(0)$ \\
\hline $\begin{array}{l}\text { share of } \\
\text { solar }\end{array}$ & $0(0)$ & $0(0)$ & $0(0)$ & $0(0)$ & $0(0)$ & $0(0)$ & $0(0)$ & $0(0)$ & $0(0)$ & $0(0)$ & $0(0)$ & $0(0)$ \\
\hline $\begin{array}{l}\text { unit } \\
\text { emissions } \\
{[\mathrm{kg}} \\
\left.\mathrm{CO}_{2} / \mathrm{kWh}\right]\end{array}$ & $\begin{array}{l}0,16 \\
(0,03)\end{array}$ & $\begin{array}{l}0,16 \\
(0,03)\end{array}$ & $\begin{array}{l}0,15 \\
(0,02)\end{array}$ & $\begin{array}{l}0,16 \\
(0,03)\end{array}$ & $\begin{array}{l}0,16 \\
(0,02)\end{array}$ & $\begin{array}{l}0,16 \\
(0,02)\end{array}$ & $\begin{array}{l}0,15 \\
(0,03)\end{array}$ & $\begin{array}{l}0,16 \\
(0,02)\end{array}$ & $\begin{array}{l}0,16 \\
(0,03)\end{array}$ & $\begin{array}{l}0,15 \\
(0,02)\end{array}$ & $\begin{array}{l}0,15 \\
(0,03)\end{array}$ & $\begin{array}{l}0,16 \\
(0,02)\end{array}$ \\
\hline $\begin{array}{l}\text { annual } \\
\text { installation } \\
\text { cost [thous.] }\end{array}$ & $\begin{array}{l}98.29 \\
(54.5) \\
\end{array}$ & $\begin{array}{l}99.88 \\
(51.1)\end{array}$ & $\begin{array}{l}91.29 \\
(56.2) \\
\end{array}$ & $\begin{array}{l}83.31 \\
(55.6)\end{array}$ & $\begin{array}{l}100.89 \\
(60.8)\end{array}$ & $\begin{array}{l}79.909 \\
(59.2) \\
\end{array}$ & $\begin{array}{l}85.09 \\
(62.4) \\
\end{array}$ & $\begin{array}{l}83.46 \\
(55.5) \\
\end{array}$ & $\begin{array}{l}96.63 \\
(51.8) \\
\end{array}$ & $\begin{array}{l}97.03 \\
(54.4) \\
\end{array}$ & $\begin{array}{r}90.96 \\
(58.4) \\
\end{array}$ & $\begin{array}{l}78.67 \\
(54.8) \\
\end{array}$ \\
\hline $\begin{array}{l}\text { electricity } \\
\text { price }\end{array}$ & $\begin{array}{l}0,17 \\
(0,07)\end{array}$ & $\begin{array}{l}0,16 \\
(0,05) \\
\end{array}$ & $\begin{array}{l}0,16 \\
(0,05) \\
\end{array}$ & $\begin{array}{l}0,19 \\
(0,08) \\
\end{array}$ & $\begin{array}{l}0,17 \\
(0,05)\end{array}$ & $\begin{array}{l}0,19 \\
(0,1) \\
\end{array}$ & $\begin{array}{l}0,16 \\
(0,05) \\
\end{array}$ & $\begin{array}{l}0,16 \\
(0,04) \\
\end{array}$ & $\begin{array}{l}0,19 \\
(0,1) \\
\end{array}$ & $\begin{array}{l}0,19 \\
(0,16)\end{array}$ & $\begin{array}{l}0,19 \\
(0,08)\end{array}$ & $\begin{array}{l}0,18 \\
(0,16) \\
\end{array}$ \\
\hline $\begin{array}{l}\text { gasoline } \\
\text { price }\end{array}$ & $\begin{array}{l}1,68 \\
(0,5)\end{array}$ & $\begin{array}{l}1,66 \\
(0,45)\end{array}$ & $\begin{array}{l}1,62 \\
(0,46)\end{array}$ & $\begin{array}{l}1,68 \\
(0,47)\end{array}$ & $\begin{array}{l}1,72 \\
(0,47)\end{array}$ & $\begin{array}{l}1,77 \\
(0,45)\end{array}$ & $\begin{array}{l}1,59 \\
(0,45)\end{array}$ & $\begin{array}{l}1,63 \\
(0,41)\end{array}$ & $\begin{array}{l}1,71 \\
(0,41)\end{array}$ & $\begin{array}{l}1,66 \\
(0,46)\end{array}$ & $\begin{array}{l}1,73 \\
(0,49)\end{array}$ & $\begin{array}{l}1,75 \\
(0,48)\end{array}$ \\
\hline diesel price & $\begin{array}{l}1,66 \\
(0,47)\end{array}$ & $\begin{array}{l}1,55 \\
(0,45)\end{array}$ & $\begin{array}{l}1,7 \\
(0,49)\end{array}$ & $\begin{array}{l}1,7 \\
(0,49)\end{array}$ & $\begin{array}{l}1,74 \\
(0,47)\end{array}$ & $\begin{array}{l}1,64 \\
(0,5)\end{array}$ & $\begin{array}{l}1,7 \\
(0,52)\end{array}$ & $\begin{array}{l}1,71 \\
(0,49)\end{array}$ & $\begin{array}{l}1,62 \\
(0,48)\end{array}$ & $\begin{array}{l}1,7 \\
(0,45)\end{array}$ & $\begin{array}{l}1,54 \\
(0,43)\end{array}$ & $\begin{array}{l}1,57 \\
(0,44)\end{array}$ \\
\hline $\begin{array}{l}\text { share of } \\
\text { electric cars }\end{array}$ & $\begin{array}{l}0,03 \\
(0,01)\end{array}$ & $\begin{array}{l}0,03 \\
(0,01)\end{array}$ & $\begin{array}{l}0,03 \\
(0,01)\end{array}$ & $\begin{array}{l}0,02 \\
(0)\end{array}$ & $\begin{array}{l}0,02 \\
(0)\end{array}$ & $\begin{array}{l}0,02 \\
(0)\end{array}$ & $\begin{array}{l}0,03 \\
(0)\end{array}$ & $\begin{array}{l}0,03 \\
(0)\end{array}$ & $\begin{array}{l}0,03 \\
(0)\end{array}$ & $\begin{array}{l}0,03 \\
(0)\end{array}$ & $\begin{array}{l}0,03 \\
(0)\end{array}$ & $\begin{array}{l}0,03 \\
(0)\end{array}$ \\
\hline $\begin{array}{l}\text { emissions } \\
{[\mathrm{mln} \text { tonnes }} \\
\text { of } \mathrm{CO} 2]\end{array}$ & $\begin{array}{l}41,25 \\
(2,25) \\
\end{array}$ & $\begin{array}{l}37,55 \\
(1,48) \\
\end{array}$ & $\begin{array}{l}37,76 \\
(2,19) \\
\end{array}$ & $\begin{array}{l}44,8 \\
(2,41) \\
\end{array}$ & $\begin{array}{l}40,91 \\
(1,49) \\
\end{array}$ & $\begin{array}{l}41,07 \\
(1,91) \\
\end{array}$ & $\begin{array}{l}44,77 \\
(2,19) \\
\end{array}$ & $\begin{array}{l}40,03 \\
(1,51) \\
\end{array}$ & $\begin{array}{l}40,04 \\
(1,8) \\
\end{array}$ & $\begin{array}{l}47,54 \\
(2,27) \\
\end{array}$ & $\begin{array}{l}44,42 \\
(1,51) \\
\end{array}$ & $\begin{array}{l}44,34 \\
(2,02) \\
\end{array}$ \\
\hline $\begin{array}{l}\text { mean FC of } \\
\text { petrol cars }\end{array}$ & $\begin{array}{l}4,48 \\
(0,01) \\
\end{array}$ & $\begin{array}{l}4,48 \\
(0,01) \\
\end{array}$ & $\begin{array}{l}4,48 \\
(0,01) \\
\end{array}$ & $\begin{array}{l}4,85 \\
(0,09) \\
\end{array}$ & $\begin{array}{l}4,83 \\
(0,08) \\
\end{array}$ & $\begin{array}{l}4,82 \\
(0,08) \\
\end{array}$ & $\begin{array}{l}4,79 \\
(0) \\
\end{array}$ & $\begin{array}{l}4,79 \\
(0) \\
\end{array}$ & $\begin{array}{l}4,79 \\
(0) \\
\end{array}$ & $\begin{array}{l}5,31 \\
(0) \\
\end{array}$ & $\begin{array}{l}5,31 \\
(0) \\
\end{array}$ & $\begin{array}{l}5,31 \\
(0) \\
\end{array}$ \\
\hline $\begin{array}{l}\text { mean FC of } \\
\text { diesel cars }\end{array}$ & $\begin{array}{l}3,22 \\
(0,01)\end{array}$ & $\begin{array}{l}3,22 \\
(0,01)\end{array}$ & $\begin{array}{l}3,23 \\
(0,01)\end{array}$ & $\begin{array}{l}3,4 \\
(0,03)\end{array}$ & $\begin{array}{l}3,4 \\
(0,03)\end{array}$ & $\begin{array}{l}3,4 \\
(0,04)\end{array}$ & $\begin{array}{l}3,35 \\
(0)\end{array}$ & $\begin{array}{l}3,35 \\
(0)\end{array}$ & $\begin{array}{l}3,35 \\
(0)\end{array}$ & $\begin{array}{l}3,63 \\
(0)\end{array}$ & $\begin{array}{l}3,63 \\
(0)\end{array}$ & $\begin{array}{l}3,63 \\
(0)\end{array}$ \\
\hline $\begin{array}{l}\text { mean annual } \\
\text { distance by } \\
\text { petrol cars }\end{array}$ & $\begin{array}{l}14934 \\
(893)\end{array}$ & $\begin{array}{l}13604 \\
(558)\end{array}$ & $\begin{array}{l}13395 \\
(941)\end{array}$ & $\begin{array}{l}14633 \\
(1024)\end{array}$ & $\begin{array}{l}13397 \\
(740)\end{array}$ & $\begin{array}{l}13503 \\
(834)\end{array}$ & $\begin{array}{l}14873 \\
(1085)\end{array}$ & $\begin{array}{l}13349 \\
(693)\end{array}$ & $\begin{array}{l}13486 \\
(942)\end{array}$ & $\begin{array}{l}14518 \\
(936)\end{array}$ & $\begin{array}{l}13554 \\
(606)\end{array}$ & $\begin{array}{l}13627 \\
(844)\end{array}$ \\
\hline $\begin{array}{l}\text { mean annual } \\
\text { distance by } \\
\text { diesel cars }\end{array}$ & $\begin{array}{l}14791 \\
(1094)\end{array}$ & $\begin{array}{l}13523 \\
(660)\end{array}$ & $\begin{array}{l}13699 \\
(896)\end{array}$ & $\begin{array}{l}14777 \\
(1005)\end{array}$ & $\begin{array}{l}13562 \\
(633)\end{array}$ & $\begin{array}{l}13588 \\
(807)\end{array}$ & $\begin{array}{l}15088 \\
(947)\end{array}$ & $\begin{array}{l}13450 \\
(636)\end{array}$ & $\begin{array}{l}13393 \\
(7261)\end{array}$ & $\begin{array}{l}14597 \\
(1050)\end{array}$ & $\begin{array}{l}13672 \\
(717)\end{array}$ & $\begin{array}{l}13549 \\
(738)\end{array}$ \\
\hline Subsidy & $\begin{array}{l}624,6 \\
(25,3)\end{array}$ & $\begin{array}{l}624,76 \\
(24,8)\end{array}$ & $\begin{array}{l}627,23 \\
(19,3)\end{array}$ & $\begin{array}{l}623,94 \\
(25,6)\end{array}$ & $\begin{array}{l}623,9 \\
(20,7) \\
\end{array}$ & $\begin{array}{l}625,02 \\
(22,1)\end{array}$ & $\begin{array}{l}631,39 \\
(25,5)\end{array}$ & $\begin{array}{l}623,83 \\
(22,6) \\
\end{array}$ & $\begin{array}{l}623,71 \\
(29,5)\end{array}$ & $\begin{array}{l}626,28 \\
(20,2)\end{array}$ & $\begin{array}{l}627,61 \\
(25,0)\end{array}$ & $\begin{array}{l}625,56 \\
(22,7) \\
\end{array}$ \\
\hline $\begin{array}{l}\text { Annual cost } \\
\text { of subsidy } \\
\text { [million] }\end{array}$ & $\begin{array}{l}51,76 \\
(16,0)\end{array}$ & $\begin{array}{c}48,99 \\
(14,1)\end{array}$ & $\begin{array}{l}50,55 \\
(10,8)\end{array}$ & $\begin{array}{l}34,45 \\
(3,21)\end{array}$ & $\begin{array}{l}33,94 \\
(3,29)\end{array}$ & $\begin{array}{l}34,93 \\
(3,91)\end{array}$ & $\begin{array}{l}48,6 \\
(4,94)\end{array}$ & $\begin{array}{l}47,53 \\
(3,37)\end{array}$ & $\begin{array}{l}47,1 \\
(5,62)\end{array}$ & $\begin{array}{l}62,72 \\
(2,64)\end{array}$ & $\begin{array}{l}63,11 \\
(2,97)\end{array}$ & $\begin{array}{l}62,64 \\
(3,05)\end{array}$ \\
\hline
\end{tabular}


Table B.4. Scenario 2050 + optimal subsidy, mean values over time from 100 simulations with different initial seeds

\begin{tabular}{|c|c|c|c|c|c|c|c|c|c|c|c|c|}
\hline & $\begin{array}{l}\mathrm{AR}_{-} \\
\mathrm{DH}\end{array}$ & $\begin{array}{l}\mathrm{AR}_{-} \\
\mathrm{DL}\end{array}$ & $\begin{array}{l}\text { AR_- } \\
\text { DR }\end{array}$ & $\begin{array}{l}\mathrm{AL}_{-} \\
\mathrm{AH}\end{array}$ & $\begin{array}{l}\mathrm{AL}_{-} \\
\mathrm{DL}\end{array}$ & $\begin{array}{l}\mathrm{AL}_{-} \\
\mathrm{DR}\end{array}$ & $\begin{array}{l}\mathrm{AM}_{-} \\
\mathrm{DH}\end{array}$ & $\begin{array}{l}\mathrm{AM}_{-} \\
\mathrm{DL}\end{array}$ & $\begin{array}{l}\mathrm{AM}_{-} \\
\mathrm{DR}\end{array}$ & $\begin{array}{l}\mathrm{AH}_{-} \\
\mathrm{DH}\end{array}$ & $\begin{array}{l}\mathrm{AH}_{-} \\
\mathrm{DL}\end{array}$ & $\begin{array}{l}\mathrm{AH}_{-} \\
\mathrm{DR}\end{array}$ \\
\hline share of coal & $\begin{array}{l}0,1 \\
(0,06)\end{array}$ & $\begin{array}{l}0,12 \\
(0,07)\end{array}$ & $\begin{array}{l}0,12 \\
(0,05)\end{array}$ & $\begin{array}{l}0,1 \\
(0,06)\end{array}$ & $\begin{array}{l}0,1 \\
(0,05)\end{array}$ & $\begin{array}{l}0,12 \\
(0,07)\end{array}$ & $\begin{array}{l}0,12 \\
(0,07)\end{array}$ & $\begin{array}{l}0,11 \\
(0,05)\end{array}$ & $\begin{array}{l}0,11 \\
(0,07)\end{array}$ & $\begin{array}{l}0,11 \\
(0,05)\end{array}$ & $\begin{array}{l}0,11 \\
(0,06)\end{array}$ & $\begin{array}{l}0,1 \\
(0,05)\end{array}$ \\
\hline $\begin{array}{l}\text { share of } \\
\text { nuclear }\end{array}$ & $\begin{array}{l}0,26 \\
(0,02)\end{array}$ & $\begin{array}{l}0,27 \\
(0,02)\end{array}$ & $\begin{array}{l}0,26 \\
(0,02)\end{array}$ & $\begin{array}{l}0,26 \\
(0,02)\end{array}$ & $\begin{array}{l}0,27 \\
(0,02)\end{array}$ & $\begin{array}{l}0,26 \\
(0,02)\end{array}$ & $\begin{array}{l}0,26 \\
(0,02)\end{array}$ & $\begin{array}{l}0,26 \\
(0,02)\end{array}$ & $\begin{array}{l}0,27 \\
(0,02)\end{array}$ & $\begin{array}{l}0,26 \\
(0,02)\end{array}$ & $\begin{array}{l}0,27 \\
(0,02)\end{array}$ & $\begin{array}{l}0,26 \\
(0,02)\end{array}$ \\
\hline share of gas & $\begin{array}{l}0,07 \\
(0,04)\end{array}$ & $\begin{array}{l}0,07 \\
(0,05)\end{array}$ & $\begin{array}{l}0,06 \\
(0,05)\end{array}$ & $\begin{array}{l}0,09 \\
(0,06)\end{array}$ & $\begin{array}{l}0,07 \\
(0,05)\end{array}$ & $\begin{array}{l}0,06 \\
(0,05)\end{array}$ & $\begin{array}{l}0,06 \\
(0,06)\end{array}$ & $\begin{array}{l}0,07 \\
(0,05)\end{array}$ & $\begin{array}{l}0,06 \\
(0,05)\end{array}$ & $\begin{array}{l}0,07 \\
(0,06)\end{array}$ & $\begin{array}{l}0,06 \\
(0,05)\end{array}$ & $\begin{array}{l}0,07 \\
(0,05)\end{array}$ \\
\hline $\begin{array}{l}\text { share of } \\
\text { biomass }\end{array}$ & $\begin{array}{l}0,38 \\
(0,09)\end{array}$ & $\begin{array}{l}0,39 \\
(0,09) \\
\end{array}$ & $\begin{array}{l}0,4 \\
(0,09)\end{array}$ & $\begin{array}{l}0,41 \\
(0,09)\end{array}$ & $\begin{array}{l}0,4 \\
(0,08)\end{array}$ & $\begin{array}{l}0,38 \\
(0,08)\end{array}$ & $\begin{array}{l}0,4 \\
(0,08)\end{array}$ & $\begin{array}{l}0,4 \\
(0,08)\end{array}$ & $\begin{array}{l}0,4 \\
(0,09)\end{array}$ & $\begin{array}{l}0,38 \\
(0,08) \\
\end{array}$ & $\begin{array}{l}0,4 \\
(0,1)\end{array}$ & $\begin{array}{l}0,38 \\
(0,07)\end{array}$ \\
\hline $\begin{array}{l}\text { share of } \\
\text { wind }\end{array}$ & $\begin{array}{l}0,17 \\
(0,07)\end{array}$ & $\begin{array}{l}0,14 \\
(0,07)\end{array}$ & $\begin{array}{l}0,14 \\
(0,07)\end{array}$ & $\begin{array}{l}0,13 \\
(0,07)\end{array}$ & $\begin{array}{l}0,14 \\
(0,08) \\
\end{array}$ & $\begin{array}{l}0,16 \\
(0,08)\end{array}$ & $\begin{array}{l}0,14 \\
(0,08)\end{array}$ & $\begin{array}{l}0,14 \\
(0,07)\end{array}$ & $\begin{array}{l}0,15 \\
(0,08)\end{array}$ & $\begin{array}{l}0,14 \\
(0,06)\end{array}$ & $\begin{array}{l}0,13 \\
(0,08) \\
\end{array}$ & $\begin{array}{l}0,17 \\
(0,07)\end{array}$ \\
\hline $\begin{array}{l}\text { share of } \\
\text { solar }\end{array}$ & $\begin{array}{l}0,02 \\
(0,04)\end{array}$ & $\begin{array}{l}0,02 \\
(0,03)\end{array}$ & $\begin{array}{l}0,02 \\
(0,03)\end{array}$ & $\begin{array}{l}0,02 \\
(0,03)\end{array}$ & $\begin{array}{l}0,02 \\
(0,03)\end{array}$ & $\begin{array}{l}0,02 \\
(0,02)\end{array}$ & $\begin{array}{l}0,02 \\
(0,03)\end{array}$ & $\begin{array}{l}0,02 \\
(0,03)\end{array}$ & $\begin{array}{l}0,01 \\
(0,02)\end{array}$ & $\begin{array}{l}0,02 \\
(0,03)\end{array}$ & $\begin{array}{l}0,03 \\
(0,03)\end{array}$ & $\begin{array}{l}0,02 \\
(0,03)\end{array}$ \\
\hline $\begin{array}{l}\text { unit } \\
\text { emissions } \\
{[\mathrm{kg}} \\
\mathrm{CO} 2 / \mathrm{kWh}]\end{array}$ & $\begin{array}{l}0,05 \\
(0,02)\end{array}$ & $\begin{array}{l}0,05 \\
(0,02)\end{array}$ & $\begin{array}{l}0,05 \\
(0,02)\end{array}$ & $\begin{array}{l}0,05 \\
(0,02)\end{array}$ & $\begin{array}{l}0,05 \\
(0,02)\end{array}$ & $\begin{array}{l}0,05 \\
(0,02)\end{array}$ & $\begin{array}{l}0,05 \\
(0,03) \\
\end{array}$ & $\begin{array}{l}0,05 \\
(0,02)\end{array}$ & $\begin{array}{l}0,05 \\
(0,02) \\
\end{array}$ & $\begin{array}{l}0,05 \\
(0,02)\end{array}$ & $\begin{array}{l}0,05 \\
(0,02)\end{array}$ & $\begin{array}{l}0,05 \\
(0,02)\end{array}$ \\
\hline $\begin{array}{l}\text { annual } \\
\text { installation } \\
\text { cost [thous.] }\end{array}$ & $\begin{array}{l}440.57 \\
(223) \\
\end{array}$ & $\begin{array}{l}383.32 \\
(220) \\
\end{array}$ & $\begin{array}{l}406.72 \\
(227) \\
\end{array}$ & $\begin{array}{l}440.99 \\
(227)\end{array}$ & $\begin{array}{l}392.65 \\
(204)\end{array}$ & $\begin{array}{l}321.82 \\
(207)\end{array}$ & $\begin{array}{l}379.14 \\
(225)\end{array}$ & $\begin{array}{l}40734 \\
(236) \\
\end{array}$ & $\begin{array}{l}396.18 \\
(225) \\
\end{array}$ & $\begin{array}{l}402.70 \\
(246) \\
\end{array}$ & $\begin{array}{l}458.75 \\
(232) \\
\end{array}$ & $\begin{array}{l}397.89 \\
(208) \\
\end{array}$ \\
\hline $\begin{array}{l}\text { electricity } \\
\text { price }\end{array}$ & $\begin{array}{l}0,67 \\
(0,28) \\
\end{array}$ & $\begin{array}{l}0,61 \\
(0,26)\end{array}$ & $\begin{array}{l}0,61 \\
(0,27)\end{array}$ & $\begin{array}{l}0,58 \\
(0,22)\end{array}$ & $\begin{array}{l}0,65 \\
(0,27) \\
\end{array}$ & $\begin{array}{l}0,6 \\
(0,28)\end{array}$ & $\begin{array}{l}0,57 \\
(0,26) \\
\end{array}$ & $\begin{array}{l}0,62 \\
(0,29) \\
\end{array}$ & $\begin{array}{l}0,62 \\
(0,27) \\
\end{array}$ & $\begin{array}{l}0,68 \\
(0,29) \\
\end{array}$ & $\begin{array}{l}0,68 \\
(0,28) \\
\end{array}$ & $\begin{array}{l}0,62 \\
(0,24) \\
\end{array}$ \\
\hline $\begin{array}{l}\text { gasoline } \\
\text { price }\end{array}$ & $\begin{array}{l}1,7 \\
(0,43)\end{array}$ & $\begin{array}{l}1,7 \\
(0,52)\end{array}$ & $\begin{array}{l}1,66 \\
(0,48)\end{array}$ & $\begin{array}{l}1,71 \\
(0,47)\end{array}$ & $\begin{array}{l}1,63 \\
(0,4)\end{array}$ & $\begin{array}{l}1,61 \\
(0,45)\end{array}$ & $\begin{array}{l}1,73 \\
(0,51)\end{array}$ & $\begin{array}{l}1,65 \\
(0,55)\end{array}$ & $\begin{array}{l}1,72 \\
(0,48)\end{array}$ & $\begin{array}{l}1,7 \\
(0,46)\end{array}$ & $\begin{array}{l}1,7 \\
(0,43)\end{array}$ & $\begin{array}{l}1,55 \\
(0,38) \\
\end{array}$ \\
\hline diesel price & $\begin{array}{l}1,59 \\
(0,48)\end{array}$ & $\begin{array}{l}1,69 \\
(0,46)\end{array}$ & $\begin{array}{l}1,66 \\
(0,48)\end{array}$ & $\begin{array}{l}1,67 \\
(0,49)\end{array}$ & $\begin{array}{l}1,69 \\
(0,47)\end{array}$ & $\begin{array}{l}1,76 \\
(0,45)\end{array}$ & $\begin{array}{l}1,54 \\
(0,4)\end{array}$ & $\begin{array}{l}1,62 \\
(0,48)\end{array}$ & $\begin{array}{l}1,64 \\
(0,48)\end{array}$ & $\begin{array}{l}1,74 \\
(0,42)\end{array}$ & $\begin{array}{l}1,55 \\
(0,43)\end{array}$ & $\begin{array}{l}1,64 \\
(0,38)\end{array}$ \\
\hline $\begin{array}{l}\text { share of } \\
\text { electric cars }\end{array}$ & $\begin{array}{l}0,01 \\
(0)\end{array}$ & $\begin{array}{l}0,01 \\
(0)\end{array}$ & $\begin{array}{l}0,01 \\
(0)\end{array}$ & $\begin{array}{l}0,02 \\
(0)\end{array}$ & $\begin{array}{l}0,02 \\
(0)\end{array}$ & $\begin{array}{l}0,02 \\
(0)\end{array}$ & $\begin{array}{l}0,02 \\
(0)\end{array}$ & $\begin{array}{l}0,02 \\
(0)\end{array}$ & $\begin{array}{l}0,02 \\
(0)\end{array}$ & $\begin{array}{l}0,04 \\
(0)\end{array}$ & $\begin{array}{l}0,04 \\
(0)\end{array}$ & $\begin{array}{l}0,04 \\
(0)\end{array}$ \\
\hline $\begin{array}{l}\text { emissions } \\
{[\mathrm{mln} \text { tonnes }} \\
\text { of } \mathrm{CO} 2]\end{array}$ & $\begin{array}{l}41,58 \\
(1,94) \\
\end{array}$ & $\begin{array}{l}37,33 \\
(2,08) \\
\end{array}$ & $\begin{array}{l}37,71 \\
(2,04) \\
\end{array}$ & $\begin{array}{l}44,46 \\
(1,86) \\
\end{array}$ & $\begin{array}{l}40,84 \\
(1,55) \\
\end{array}$ & $\begin{array}{l}40,44 \\
(1,94) \\
\end{array}$ & $\begin{array}{l}43,87 \\
(2)\end{array}$ & $\begin{array}{l}40,35 \\
(1,31) \\
\end{array}$ & $\begin{array}{l}39,85 \\
(1,59) \\
\end{array}$ & $\begin{array}{l}47,96 \\
(2,23) \\
\end{array}$ & $\begin{array}{l}43,7 \\
(1,49) \\
\end{array}$ & $\begin{array}{l}43,49 \\
(1,8) \\
\end{array}$ \\
\hline $\begin{array}{l}\text { mean FC of } \\
\text { petrol cars }\end{array}$ & $\begin{array}{l}4,48 \\
(0,01) \\
\end{array}$ & $\begin{array}{l}4,48 \\
(0,01) \\
\end{array}$ & $\begin{array}{l}4,48 \\
(0,01) \\
\end{array}$ & $\begin{array}{l}4,85 \\
(0,08) \\
\end{array}$ & $\begin{array}{l}4,86 \\
(0,08) \\
\end{array}$ & $\begin{array}{l}4,86 \\
(0,08) \\
\end{array}$ & $\begin{array}{l}4,79 \\
(0)\end{array}$ & $\begin{array}{l}4,79 \\
(0) \\
\end{array}$ & $\begin{array}{l}4,79 \\
(0) \\
\end{array}$ & $\begin{array}{l}5,31 \\
(0) \\
\end{array}$ & $\begin{array}{l}5,31 \\
(0) \\
\end{array}$ & $\begin{array}{l}5,31 \\
(0) \\
\end{array}$ \\
\hline $\begin{array}{l}\text { mean FC of } \\
\text { diesel cars }\end{array}$ & $\begin{array}{l}3,22 \\
(0,01)\end{array}$ & $\begin{array}{l}3,22 \\
(0,01)\end{array}$ & $\begin{array}{l}3,22 \\
(0,01)\end{array}$ & $\begin{array}{l}3,4 \\
(0,04)\end{array}$ & $\begin{array}{l}3,4 \\
(0,03)\end{array}$ & $\begin{array}{l}3,39 \\
(0,04)\end{array}$ & $\begin{array}{l}3,35 \\
(0)\end{array}$ & $\begin{array}{l}3,35 \\
(0)\end{array}$ & $\begin{array}{l}3,35 \\
(0)\end{array}$ & $\begin{array}{l}3,63 \\
(0)\end{array}$ & $\begin{array}{l}3,63 \\
(0)\end{array}$ & $\begin{array}{l}3,63 \\
(0)\end{array}$ \\
\hline $\begin{array}{l}\text { mean annual } \\
\text { distance by } \\
\text { petrol cars }\end{array}$ & $\begin{array}{l}15055 \\
(781)\end{array}$ & $\begin{array}{l}13278 \\
(592)\end{array}$ & $\begin{array}{l}13477 \\
(707)\end{array}$ & $\begin{array}{l}14841 \\
(846)\end{array}$ & $\begin{array}{l}13541 \\
(654)\end{array}$ & $\begin{array}{l}13311 \\
(812)\end{array}$ & $\begin{array}{l}14904 \\
(1030)\end{array}$ & $\begin{array}{l}13505 \\
(523)\end{array}$ & $\begin{array}{l}13381 \\
(811)\end{array}$ & $\begin{array}{l}14961 \\
(1035)\end{array}$ & $\begin{array}{l}13515 \\
(734)\end{array}$ & $\begin{array}{l}13381 \\
(815)\end{array}$ \\
\hline $\begin{array}{l}\text { mean annual } \\
\text { distance by } \\
\text { diesel cars }\end{array}$ & $\begin{array}{l}14743 \\
(983)\end{array}$ & $\begin{array}{l}13473 \\
(580)\end{array}$ & $\begin{array}{l}13432 \\
(912)\end{array}$ & $\begin{array}{l}14607 \\
(784)\end{array}$ & $\begin{array}{l}13449 \\
(644)\end{array}$ & $\begin{array}{l}13396 \\
(872)\end{array}$ & $\begin{array}{l}14566 \\
(722)\end{array}$ & $\begin{array}{l}13530 \\
(633)\end{array}$ & $\begin{array}{l}13341 \\
(799)\end{array}$ & $\begin{array}{l}14794 \\
(909)\end{array}$ & $\begin{array}{l}13548 \\
(634)\end{array}$ & $\begin{array}{l}13549 \\
(869)\end{array}$ \\
\hline Subsidy & $\begin{array}{l}723,61 \\
(19,9)\end{array}$ & $\begin{array}{l}719,02 \\
(22,1)\end{array}$ & $\begin{array}{l}718,65 \\
(18,5)\end{array}$ & $\begin{array}{l}720,79 \\
(22,9)\end{array}$ & $\begin{array}{l}722,87 \\
(17,4)\end{array}$ & $\begin{array}{l}719,24 \\
(22,3)\end{array}$ & $\begin{array}{l}719,3 \\
(23,9)\end{array}$ & $\begin{array}{l}722,6 \\
(13,9)\end{array}$ & $\begin{array}{l}721,38 \\
(22,2)\end{array}$ & $\begin{array}{l}718,81 \\
(17,9)\end{array}$ & $\begin{array}{l}722,11 \\
(22,3)\end{array}$ & $\begin{array}{l}723,82 \\
(18,8)\end{array}$ \\
\hline $\begin{array}{l}\text { Annual cost } \\
\text { of subsidy } \\
\text { [million] }\end{array}$ & $\begin{array}{l}25,43 \\
(11,0)\end{array}$ & $\begin{array}{l}29,58 \\
(14,9)\end{array}$ & $\begin{array}{l}28,26 \\
(12,8)\end{array}$ & $\begin{array}{l}45,49 \\
(6,12) \\
\end{array}$ & $\begin{array}{l}42,82 \\
(7,47)\end{array}$ & $\begin{array}{l}43,85 \\
(7,25) \\
\end{array}$ & $\begin{array}{l}40,93 \\
(5,32)\end{array}$ & $\begin{array}{l}40,33 \\
(5,42) \\
\end{array}$ & $\begin{array}{l}40,46 \\
(5,58)\end{array}$ & $\begin{array}{l}77,91 \\
(2,8)\end{array}$ & $\begin{array}{l}78,51 \\
(3,48)\end{array}$ & $\begin{array}{l}78,44 \\
(3,36) \\
\end{array}$ \\
\hline
\end{tabular}


Table B.5. Scenario $2010+€ 5000$ subsidy, mean values over time from 100 simulations with different initial seeds

\begin{tabular}{|c|c|c|c|c|c|c|c|c|c|c|c|c|}
\hline & $\begin{array}{l}\mathrm{AR}_{-} \\
\mathrm{DH}\end{array}$ & $\begin{array}{l}\mathrm{AR}_{-} \\
\mathrm{DL}\end{array}$ & $\begin{array}{l}\mathrm{AR}_{-} \\
\mathrm{DR}\end{array}$ & $\begin{array}{l}\text { AL_A } \\
\mathrm{H}\end{array}$ & $\begin{array}{l}\text { AL_D } \\
\mathrm{L}\end{array}$ & $\begin{array}{l}\mathrm{AL} \mathrm{R}_{-} \mathrm{D} \\
\mathrm{R}\end{array}$ & $\begin{array}{l}\mathrm{AM}_{-} \\
\mathrm{DH}\end{array}$ & $\begin{array}{l}\mathrm{AM}_{-} \\
\mathrm{DL}\end{array}$ & $\begin{array}{l}\mathrm{AM}_{-} \\
\mathrm{DR}\end{array}$ & $\begin{array}{l}\mathrm{AH}_{-} \\
\mathrm{DH}^{-}\end{array}$ & $\begin{array}{l}\mathrm{AH}_{-} \\
\mathrm{DL}\end{array}$ & $\begin{array}{l}\mathrm{AH}_{-} \\
\mathrm{DR}\end{array}$ \\
\hline share of coal & $\begin{array}{l}0,4 \\
(0,08)\end{array}$ & $\begin{array}{l}0,4 \\
(0,08)\end{array}$ & $\begin{array}{l}0,39 \\
(0,07)\end{array}$ & $\begin{array}{l}0,39 \\
(0,08)\end{array}$ & $\begin{array}{l}0,41 \\
(0,07)\end{array}$ & $\begin{array}{l}0,39 \\
(0,07)\end{array}$ & $\begin{array}{l}0,38 \\
(0,08)\end{array}$ & $\begin{array}{l}0,39 \\
(0,09)\end{array}$ & $\begin{array}{l}0,4 \\
(0,09)\end{array}$ & $\begin{array}{l}0,39 \\
(0,06)\end{array}$ & $\begin{array}{l}0,39 \\
(0,07)\end{array}$ & $\begin{array}{l}0,39 \\
(0,07)\end{array}$ \\
\hline $\begin{array}{l}\text { share of } \\
\text { nuclear }\end{array}$ & $\begin{array}{l}0,52 \\
(0,08)\end{array}$ & $\begin{array}{l}0,52 \\
(0,08)\end{array}$ & $\begin{array}{l}0,52 \\
(0,06)\end{array}$ & $\begin{array}{l}0,51 \\
(0,09)\end{array}$ & $\begin{array}{l}0,52 \\
(0,07)\end{array}$ & $\begin{array}{l}0,51 \\
(0,08)\end{array}$ & $\begin{array}{l}0,54 \\
(0,09)\end{array}$ & $\begin{array}{l}0,51 \\
(0,06)\end{array}$ & $\begin{array}{l}0,51 \\
(0,1)\end{array}$ & $\begin{array}{l}0,52 \\
(0,07)\end{array}$ & $\begin{array}{l}0,53 \\
(0,09) \\
\end{array}$ & $\begin{array}{l}0,52 \\
(0,08)\end{array}$ \\
\hline share of gas & $\begin{array}{l}0,08 \\
(0,04)\end{array}$ & $\begin{array}{l}0,09 \\
(0,05)\end{array}$ & $\begin{array}{l}0,09 \\
(0,05)\end{array}$ & $\begin{array}{l}0,1 \\
(0,06)\end{array}$ & $\begin{array}{l}0,08 \\
(0,04)\end{array}$ & $\begin{array}{l}0,1 \\
(0,05)\end{array}$ & $\begin{array}{l}0,07 \\
(0,05)\end{array}$ & $\begin{array}{l}0,1 \\
(0,06)\end{array}$ & $\begin{array}{l}0,09 \\
(0,04)\end{array}$ & $\begin{array}{l}0,1 \\
(0,04)\end{array}$ & $\begin{array}{l}0,09 \\
(0,05)\end{array}$ & $\begin{array}{l}0,09 \\
(0,04)\end{array}$ \\
\hline $\begin{array}{l}\text { share of } \\
\text { biomass }\end{array}$ & $0(0)$ & $0(0)$ & $0(0)$ & $0(0)$ & $0(0)$ & $0(0)$ & $0(0)$ & $0(0)$ & $0(0)$ & $0(0)$ & $0(0)$ & $0(0)$ \\
\hline $\begin{array}{l}\text { share of } \\
\text { wind }\end{array}$ & $0(0)$ & $0(0)$ & $0(0)$ & $0(0)$ & $0(0)$ & $0(0)$ & $0(0)$ & $0(0)$ & $0(0)$ & $0(0)$ & $0(0)$ & $0(0)$ \\
\hline $\begin{array}{l}\text { share of } \\
\text { solar }\end{array}$ & $0(0)$ & $0(0)$ & $0(0)$ & $0(0)$ & $0(0)$ & $0(0)$ & $0(0)$ & $0(0)$ & $0(0)$ & $0(0)$ & $0(0)$ & $0(0)$ \\
\hline $\begin{array}{l}\text { unit } \\
\text { emissions } \\
{[\mathrm{kg}} \\
\mathrm{CO} 2 / \mathrm{kWh}]\end{array}$ & $\begin{array}{l}0,16 \\
(0,03)\end{array}$ & $\begin{array}{l}0,16 \\
(0,03)\end{array}$ & $\begin{array}{l}0,15 \\
(0,02)\end{array}$ & $\begin{array}{l}0,16 \\
(0,03)\end{array}$ & $\begin{array}{l}0,16 \\
(0,02)\end{array}$ & $\begin{array}{l}0,16 \\
(0,02)\end{array}$ & $\begin{array}{l}0,15 \\
(0,03)\end{array}$ & $\begin{array}{l}0,16 \\
(0,02)\end{array}$ & $\begin{array}{l}0,16 \\
(0,03)\end{array}$ & $\begin{array}{l}0,15 \\
(0,02)\end{array}$ & $\begin{array}{l}0,15 \\
(0,03)\end{array}$ & $\begin{array}{l}0,16 \\
(0,02)\end{array}$ \\
\hline $\begin{array}{l}\text { annual } \\
\text { installation } \\
\text { cost [thous.] }\end{array}$ & $\begin{array}{l}98.38 \\
(54.5) \\
\end{array}$ & $\begin{array}{l}98.87 \\
(50.9)\end{array}$ & $\begin{array}{l}91.55 \\
(56.3) \\
\end{array}$ & $\begin{array}{l}82.84 \\
(54.8) \\
\end{array}$ & $\begin{array}{l}99,440 \\
(61.4)\end{array}$ & $\begin{array}{l}80.506 \\
(58.6)\end{array}$ & $\begin{array}{l}84.54 \\
(62.1) \\
\end{array}$ & $\begin{array}{c}83.54 \\
(55.5) \\
\end{array}$ & $\begin{array}{l}96.64 \\
(51.8) \\
\end{array}$ & $\begin{array}{l}97.03 \\
(54.4) \\
\end{array}$ & $\begin{array}{l}91.64 \\
(58.9) \\
\end{array}$ & $\begin{array}{l}78.93 \\
(54.8) \\
\end{array}$ \\
\hline $\begin{array}{l}\text { electricity } \\
\text { price }\end{array}$ & $\begin{array}{l}0,17 \\
(0,07)\end{array}$ & $\begin{array}{l}0,16 \\
(0,05) \\
\end{array}$ & $\begin{array}{l}0,16 \\
(0,05) \\
\end{array}$ & $\begin{array}{l}0,18 \\
(0,08) \\
\end{array}$ & $\begin{array}{l}0,17 \\
(0,05)\end{array}$ & $\begin{array}{l}0,19 \\
(0,1) \\
\end{array}$ & $\begin{array}{l}0,16 \\
(0,05)\end{array}$ & $\begin{array}{l}0,16 \\
(0,04) \\
\end{array}$ & $\begin{array}{l}0,19 \\
(0,1) \\
\end{array}$ & $\begin{array}{l}0,19 \\
(0,16) \\
\end{array}$ & $\begin{array}{l}0,19 \\
(0,08) \\
\end{array}$ & $\begin{array}{l}0,18 \\
(0,16)\end{array}$ \\
\hline $\begin{array}{l}\text { gasoline } \\
\text { price }\end{array}$ & $\begin{array}{l}1,69 \\
(0,51)\end{array}$ & $\begin{array}{l}1,65 \\
(0,45)\end{array}$ & $\begin{array}{l}1,62 \\
(0,46)\end{array}$ & $\begin{array}{l}1,68 \\
(0,47)\end{array}$ & $\begin{array}{l}1,73 \\
(0,48)\end{array}$ & $\begin{array}{l}1,77 \\
(0,45)\end{array}$ & $\begin{array}{l}1,6 \\
(0,45)\end{array}$ & $\begin{array}{l}1,63 \\
(0,41)\end{array}$ & $\begin{array}{l}1,7 \\
(0,42)\end{array}$ & $\begin{array}{l}1,66 \\
(0,46)\end{array}$ & $\begin{array}{l}1,73 \\
(0,49)\end{array}$ & $\begin{array}{l}1,74 \\
(0,48)\end{array}$ \\
\hline diesel price & $\begin{array}{l}1,67 \\
(0,47) \\
\end{array}$ & $\begin{array}{l}1,55 \\
(0,45) \\
\end{array}$ & $\begin{array}{l}1,71 \\
(0,48) \\
\end{array}$ & $\begin{array}{l}1,7 \\
(0,49) \\
\end{array}$ & $\begin{array}{l}1,73 \\
(0,48) \\
\end{array}$ & $\begin{array}{l}1,65 \\
(0,5) \\
\end{array}$ & $\begin{array}{l}1,7 \\
(0,52) \\
\end{array}$ & $\begin{array}{l}1,72 \\
(0,49) \\
\end{array}$ & $\begin{array}{l}1,62 \\
(0,48) \\
\end{array}$ & $\begin{array}{l}1,7 \\
(0,45)\end{array}$ & $\begin{array}{l}1,53 \\
(0,42) \\
\end{array}$ & $\begin{array}{l}1,58 \\
(0,44) \\
\end{array}$ \\
\hline $\begin{array}{l}\text { share of } \\
\text { electric cars }\end{array}$ & $\begin{array}{l}0,06 \\
(0,02)\end{array}$ & $\begin{array}{l}0,06 \\
(0,01)\end{array}$ & $\begin{array}{l}0,06 \\
(0,01)\end{array}$ & $\begin{array}{l}0,03 \\
(0)\end{array}$ & $\begin{array}{l}0,03 \\
(0)\end{array}$ & $\begin{array}{l}0,03 \\
(0)\end{array}$ & $\begin{array}{l}0,04 \\
(0)\end{array}$ & $\begin{array}{l}0,04 \\
(0)\end{array}$ & $\begin{array}{l}0,04 \\
(0)\end{array}$ & $\begin{array}{l}0,04 \\
(0)\end{array}$ & $\begin{array}{l}0,04 \\
(0)\end{array}$ & $\begin{array}{l}0,04 \\
(0)\end{array}$ \\
\hline $\begin{array}{l}\text { emissions } \\
\text { [mln tonnes } \\
\text { of } \mathrm{CO} 2]\end{array}$ & $\begin{array}{l}40,21 \\
(2,29)\end{array}$ & $\begin{array}{l}36,62 \\
(1,45) \\
\end{array}$ & $\begin{array}{l}36,89 \\
(2,14)\end{array}$ & $\begin{array}{l}44,49 \\
(2,39) \\
\end{array}$ & $\begin{array}{l}40,63 \\
(1,48) \\
\end{array}$ & $\begin{array}{l}40,76 \\
(1,91) \\
\end{array}$ & $\begin{array}{l}44,21 \\
(2,19)\end{array}$ & $\begin{array}{l}39,55 \\
(1,49) \\
\end{array}$ & $\begin{array}{l}39,58 \\
(1,78) \\
\end{array}$ & $\begin{array}{l}47,29 \\
(2,26) \\
\end{array}$ & $\begin{array}{l}44,16 \\
(1,49)\end{array}$ & $\begin{array}{l}44,07 \\
(2,01)\end{array}$ \\
\hline $\begin{array}{l}\text { mean FC of } \\
\text { petrol cars }\end{array}$ & $\begin{array}{l}4,48 \\
(0,01) \\
\end{array}$ & $\begin{array}{l}4,48 \\
(0,01) \\
\end{array}$ & $\begin{array}{l}4,48 \\
(0,01) \\
\end{array}$ & $\begin{array}{l}4,85 \\
(0,08) \\
\end{array}$ & $\begin{array}{l}4,83 \\
(0,09) \\
\end{array}$ & $\begin{array}{l}4,82 \\
(0,08) \\
\end{array}$ & $\begin{array}{l}4,79 \\
(0) \\
\end{array}$ & $\begin{array}{l}4,79 \\
(0) \\
\end{array}$ & $\begin{array}{l}4,79 \\
(0) \\
\end{array}$ & $\begin{array}{l}5,31 \\
(0) \\
\end{array}$ & $\begin{array}{l}5,31 \\
(0) \\
\end{array}$ & $\begin{array}{l}5,31 \\
(0) \\
\end{array}$ \\
\hline $\begin{array}{l}\text { mean FC of } \\
\text { diesel cars }\end{array}$ & $\begin{array}{l}3,22 \\
(0,01)\end{array}$ & $\begin{array}{l}3,22 \\
(0,01)\end{array}$ & $\begin{array}{l}3,23 \\
(0,01)\end{array}$ & $\begin{array}{l}3,4 \\
(0,03)\end{array}$ & $\begin{array}{l}3,4 \\
(0,03)\end{array}$ & $\begin{array}{l}3,4 \\
(0,04)\end{array}$ & $\begin{array}{l}3,35 \\
(0)\end{array}$ & $\begin{array}{l}3,35 \\
(0)\end{array}$ & $\begin{array}{l}3,35 \\
(0)\end{array}$ & $\begin{array}{l}3,63 \\
(0)\end{array}$ & $\begin{array}{l}3,63 \\
(0)\end{array}$ & $\begin{array}{l}3,63 \\
(0)\end{array}$ \\
\hline $\begin{array}{l}\text { mean annual } \\
\text { distance by } \\
\text { petrol cars }\end{array}$ & $\begin{array}{l}14916 \\
(891)\end{array}$ & $\begin{array}{l}13606 \\
(558)\end{array}$ & $\begin{array}{l}13398 \\
(943)\end{array}$ & $\begin{array}{l}14630 \\
(1023)\end{array}$ & $\begin{array}{l}13408 \\
(740)\end{array}$ & $\begin{array}{l}13504 \\
(834)\end{array}$ & $\begin{array}{l}14869 \\
(1085)\end{array}$ & $\begin{array}{l}13346 \\
(698)\end{array}$ & $\begin{array}{l}13490 \\
(940)\end{array}$ & $\begin{array}{l}14508 \\
(936)\end{array}$ & $\begin{array}{l}13555 \\
(605)\end{array}$ & $\begin{array}{l}13625 \\
(844)\end{array}$ \\
\hline $\begin{array}{l}\text { mean annual } \\
\text { distance by } \\
\text { diesel cars }\end{array}$ & $\begin{array}{l}14784 \\
(1095)\end{array}$ & $\begin{array}{l}13524 \\
(660)\end{array}$ & $\begin{array}{l}13699 \\
(894)\end{array}$ & $\begin{array}{l}14776 \\
(1005)\end{array}$ & $\begin{array}{l}13558 \\
(634)\end{array}$ & $\begin{array}{l}13582 \\
(817)\end{array}$ & $\begin{array}{l}15070 \\
(970)\end{array}$ & $\begin{array}{l}13445 \\
(638)\end{array}$ & $\begin{array}{l}13393 \\
(726)\end{array}$ & $\begin{array}{l}14613 \\
(1046)\end{array}$ & $\begin{array}{l}13673 \\
(718)\end{array}$ & $\begin{array}{l}13543 \\
(745)\end{array}$ \\
\hline Subsidy & $\begin{array}{l}5000 \\
(0)\end{array}$ & $\begin{array}{l}5000 \\
(0)\end{array}$ & $\begin{array}{l}5000 \\
(0)\end{array}$ & $\begin{array}{l}5000 \\
(0)\end{array}$ & $\begin{array}{l}5000 \\
(0)\end{array}$ & $\begin{array}{l}5000 \\
(0)\end{array}$ & $\begin{array}{l}5000 \\
(0)\end{array}$ & $\begin{array}{l}5000 \\
(0)\end{array}$ & $\begin{array}{l}5000 \\
(0)\end{array}$ & $\begin{array}{l}5000 \\
(0) \\
\end{array}$ & $\begin{array}{l}5000 \\
(0)\end{array}$ & $\begin{array}{l}5000 \\
(0) \\
\end{array}$ \\
\hline $\begin{array}{l}\text { Annual cost } \\
\text { of subsidy } \\
\text { [million] }\end{array}$ & $\begin{array}{l}917,29 \\
(281)\end{array}$ & $\begin{array}{l}864,75 \\
(247)\end{array}$ & $\begin{array}{l}893,58 \\
(187)\end{array}$ & $\begin{array}{l}420,21 \\
(30,5)\end{array}$ & $\begin{array}{l}416,26 \\
(39,1)\end{array}$ & $\begin{array}{l}426,55 \\
(46,2)\end{array}$ & $\begin{array}{l}623,64 \\
(57,5)\end{array}$ & $\begin{array}{l}618,1 \\
(40,4) \\
\end{array}$ & $\begin{array}{l}610,86 \\
(62,0)\end{array}$ & $\begin{array}{l}612,02 \\
(17,9)\end{array}$ & $\begin{array}{l}614,85 \\
(14,9) \\
\end{array}$ & $\begin{array}{l}611,94 \\
(17,9) \\
\end{array}$ \\
\hline
\end{tabular}


Table B.6. Scenario $2050+€ 5000$ subsidy, mean values over time from 100 simulations with different initial seeds

\begin{tabular}{|c|c|c|c|c|c|c|c|c|c|c|c|c|}
\hline & $\begin{array}{l}\mathrm{AR}_{-} \\
\mathrm{DH}\end{array}$ & $\begin{array}{l}\mathrm{AR}_{-} \\
\mathrm{DL}\end{array}$ & $\begin{array}{l}\mathrm{AR}- \\
\mathrm{DR}\end{array}$ & $\begin{array}{l}\text { AL_A } \\
\mathrm{H}\end{array}$ & $\begin{array}{l}\mathrm{AL} \mathrm{L}_{-} \mathrm{D} \\
\end{array}$ & $\begin{array}{l}\text { AL_D } \\
\mathrm{R}\end{array}$ & $\begin{array}{l}\mathrm{AM}_{-} \\
\mathrm{DH}\end{array}$ & $\begin{array}{l}\mathrm{AM}_{-} \\
\mathrm{DL}\end{array}$ & $\begin{array}{l}\mathrm{AM}_{-} \\
\mathrm{DR}\end{array}$ & $\begin{array}{l}\mathrm{AH}_{-} \\
\mathrm{DH}\end{array}$ & $\begin{array}{l}\mathrm{AH}_{-} \\
\mathrm{DL}\end{array}$ & $\begin{array}{l}\mathrm{AH}_{-} \\
\mathrm{DR}\end{array}$ \\
\hline share of coal & $\begin{array}{l}0.1 \\
(0.06) \\
\end{array}$ & $\begin{array}{l}0.12 \\
(0.07) \\
\end{array}$ & $\begin{array}{l}0.12 \\
(0.05) \\
\end{array}$ & $\begin{array}{l}0.1 \\
(0.06) \\
\end{array}$ & $\begin{array}{l}0.1 \\
(0.05) \\
\end{array}$ & $\begin{array}{l}0.12 \\
(0.07) \\
\end{array}$ & $\begin{array}{l}0.12 \\
(0.07) \\
\end{array}$ & $\begin{array}{l}0.11 \\
(0.05) \\
\end{array}$ & $\begin{array}{l}0.11 \\
(0.07)\end{array}$ & $\begin{array}{l}0.11 \\
(0.05) \\
\end{array}$ & $\begin{array}{l}0.11 \\
(0.06)\end{array}$ & $\begin{array}{l}0.1 \\
(0.05) \\
\end{array}$ \\
\hline $\begin{array}{l}\text { share of } \\
\text { nuclear }\end{array}$ & $\begin{array}{l}0.26 \\
(0.02)\end{array}$ & $\begin{array}{l}0.27 \\
(0.02)\end{array}$ & $\begin{array}{l}0.26 \\
(0.02)\end{array}$ & $\begin{array}{l}0.26 \\
(0.02)\end{array}$ & $\begin{array}{l}0.27 \\
(0.02)\end{array}$ & $\begin{array}{l}0.26 \\
(0.02)\end{array}$ & $\begin{array}{l}0.26 \\
(0.02)\end{array}$ & $\begin{array}{l}0.26 \\
(0.02)\end{array}$ & $\begin{array}{l}0.27 \\
(0.02)\end{array}$ & $\begin{array}{l}0.26 \\
(0.02)\end{array}$ & $\begin{array}{l}0.27 \\
(0.02)\end{array}$ & $\begin{array}{l}0.26 \\
(0.02)\end{array}$ \\
\hline share of gas & $\begin{array}{l}0.07 \\
(0.04)\end{array}$ & $\begin{array}{l}0.07 \\
(0.05)\end{array}$ & $\begin{array}{l}0.06 \\
(0.05)\end{array}$ & $\begin{array}{l}0.09 \\
(0.06)\end{array}$ & $\begin{array}{l}0.07 \\
(0.05)\end{array}$ & $\begin{array}{l}0.06 \\
(0.05)\end{array}$ & $\begin{array}{l}0.06 \\
(0.06)\end{array}$ & $\begin{array}{l}0.07 \\
(0.05)\end{array}$ & $\begin{array}{l}0.06 \\
(0.05)\end{array}$ & $\begin{array}{l}0.07 \\
(0.06)\end{array}$ & $\begin{array}{l}0.06 \\
(0.05)\end{array}$ & $\begin{array}{l}0.07 \\
(0.05)\end{array}$ \\
\hline $\begin{array}{l}\text { share of } \\
\text { biomass }\end{array}$ & $\begin{array}{l}0.38 \\
(0.09) \\
\end{array}$ & $\begin{array}{l}0.39 \\
(0.09)\end{array}$ & $\begin{array}{l}0.4 \\
(0.09)\end{array}$ & $\begin{array}{l}0.41 \\
(0.09)\end{array}$ & $\begin{array}{l}0.4 \\
(0.08)\end{array}$ & $\begin{array}{l}0.38 \\
(0.08) \\
\end{array}$ & $\begin{array}{l}0.4 \\
(0.08)\end{array}$ & $\begin{array}{l}0.4 \\
(0.08)\end{array}$ & $\begin{array}{l}0.4 \\
(0.09)\end{array}$ & $\begin{array}{l}0.38 \\
(0.08) \\
\end{array}$ & $\begin{array}{l}0.4 \\
(0.1) \\
\end{array}$ & $\begin{array}{l}0.38 \\
(0.07) \\
\end{array}$ \\
\hline $\begin{array}{l}\text { share of } \\
\text { wind }\end{array}$ & $\begin{array}{l}0.17 \\
(0.07)\end{array}$ & $\begin{array}{l}0.14 \\
(0.07) \\
\end{array}$ & $\begin{array}{l}0.14 \\
(0.07)\end{array}$ & $\begin{array}{l}0.13 \\
(0.07)\end{array}$ & $\begin{array}{l}0.14 \\
(0.08) \\
\end{array}$ & $\begin{array}{l}0.16 \\
(0.08) \\
\end{array}$ & $\begin{array}{l}0.14 \\
(0.08)\end{array}$ & $\begin{array}{l}0.14 \\
(0.07)\end{array}$ & $\begin{array}{l}0.15 \\
(0.08) \\
\end{array}$ & $\begin{array}{l}0.14 \\
(0.06) \\
\end{array}$ & $\begin{array}{l}0.13 \\
(0.08) \\
\end{array}$ & $\begin{array}{l}0.17 \\
(0.07) \\
\end{array}$ \\
\hline share of solar & $\begin{array}{l}0.02 \\
(0.04) \\
\end{array}$ & $\begin{array}{l}0.02 \\
(0.03) \\
\end{array}$ & $\begin{array}{l}0.02 \\
(0.03) \\
\end{array}$ & $\begin{array}{l}0.02 \\
(0.03)\end{array}$ & $\begin{array}{l}0.02 \\
(0.03) \\
\end{array}$ & $\begin{array}{l}0.02 \\
(0.02)\end{array}$ & $\begin{array}{l}0.02 \\
(0.03)\end{array}$ & $\begin{array}{l}0.02 \\
(0.03)\end{array}$ & $\begin{array}{l}0.01 \\
(0.02) \\
\end{array}$ & $\begin{array}{l}0.02 \\
(0.03)\end{array}$ & $\begin{array}{l}0.03 \\
(0.03) \\
\end{array}$ & $\begin{array}{l}0.02 \\
(0.03)\end{array}$ \\
\hline $\begin{array}{l}\text { unit } \\
\text { emissions } \\
{[\mathrm{kg}} \\
\mathrm{CO} 2 / \mathrm{kWh}]\end{array}$ & $\begin{array}{l}0.05 \\
(0.02)\end{array}$ & $\begin{array}{l}0.05 \\
(0.02)\end{array}$ & $\begin{array}{l}0.05 \\
(0.02)\end{array}$ & $\begin{array}{l}0.05 \\
(0.02)\end{array}$ & $\begin{array}{l}0.05 \\
(0.02)\end{array}$ & $\begin{array}{l}0.05 \\
(0.02)\end{array}$ & $\begin{array}{l}0.05 \\
(0.03)\end{array}$ & $\begin{array}{l}0.05 \\
(0.02)\end{array}$ & $\begin{array}{l}0.05 \\
(0.02)\end{array}$ & $\begin{array}{l}0.05 \\
(0.02)\end{array}$ & $\begin{array}{l}0.05 \\
(0.02)\end{array}$ & $\begin{array}{l}0.05 \\
(0.02)\end{array}$ \\
\hline $\begin{array}{l}\text { annual } \\
\text { installation } \\
\text { cost [thous.] }\end{array}$ & $\begin{array}{l}440.57 \\
(223)\end{array}$ & $\begin{array}{l}383.32 \\
(220)\end{array}$ & $\begin{array}{l}406.72 \\
(227)\end{array}$ & $\begin{array}{l}440.99 \\
(227) \\
\end{array}$ & $\begin{array}{l}392.65 \\
(203) \\
\end{array}$ & $\begin{array}{l}321.82 \\
(207) \\
\end{array}$ & $\begin{array}{l}379.14 \\
(225) \\
\end{array}$ & $\begin{array}{l}407.34 \\
(236) \\
\end{array}$ & $\begin{array}{l}396.18 \\
(225) \\
\end{array}$ & $\begin{array}{l}402.70 \\
(246)\end{array}$ & $\begin{array}{l}458.75 \\
(232) \\
\end{array}$ & $\begin{array}{l}397.89 \\
(208) \\
\end{array}$ \\
\hline $\begin{array}{l}\text { electricity } \\
\text { price }\end{array}$ & $\begin{array}{l}0.67 \\
(0.28) \\
\end{array}$ & $\begin{array}{l}0.61 \\
(0.26)\end{array}$ & $\begin{array}{l}0.61 \\
(0.27) \\
\end{array}$ & $\begin{array}{l}0.58 \\
(0.22) \\
\end{array}$ & $\begin{array}{l}0.65 \\
(0.27) \\
\end{array}$ & $\begin{array}{l}0.6 \\
(0.28) \\
\end{array}$ & $\begin{array}{l}0.57 \\
(0.26) \\
\end{array}$ & $\begin{array}{l}0.62 \\
(0.29) \\
\end{array}$ & $\begin{array}{l}0.62 \\
(0.27)\end{array}$ & $\begin{array}{l}0.68 \\
(0.29) \\
\end{array}$ & $\begin{array}{l}0.68 \\
(0.28) \\
\end{array}$ & $\begin{array}{l}0.62 \\
(0.24)\end{array}$ \\
\hline $\begin{array}{l}\text { gasoline } \\
\text { price }\end{array}$ & $\begin{array}{l}1.7 \\
(0.43)\end{array}$ & $\begin{array}{l}1.7 \\
(0.52)\end{array}$ & $\begin{array}{l}1.66 \\
(0.48)\end{array}$ & $\begin{array}{l}1.71 \\
(0.47)\end{array}$ & $\begin{array}{l}1.63 \\
(0.4) \\
\end{array}$ & $\begin{array}{l}1.61 \\
(0.45)\end{array}$ & $\begin{array}{l}1.73 \\
(0.51)\end{array}$ & $\begin{array}{l}1.65 \\
(0.55)\end{array}$ & $\begin{array}{l}1.72 \\
(0.48)\end{array}$ & $\begin{array}{l}1.7 \\
(0.46)\end{array}$ & $\begin{array}{l}1.7 \\
(0.43)\end{array}$ & $\begin{array}{l}1.55 \\
(0.38)\end{array}$ \\
\hline diesel price & $\begin{array}{l}1.59 \\
(0.48)\end{array}$ & $\begin{array}{l}1.69 \\
(0.46)\end{array}$ & $\begin{array}{l}1.66 \\
(0.48)\end{array}$ & $\begin{array}{l}1.67 \\
(0.49)\end{array}$ & $\begin{array}{l}1.69 \\
(0.47)\end{array}$ & $\begin{array}{l}1.76 \\
(0.45)\end{array}$ & $\begin{array}{l}1.54 \\
(0.4)\end{array}$ & $\begin{array}{l}1.62 \\
(0.48)\end{array}$ & $\begin{array}{l}1.64 \\
(0.48)\end{array}$ & $\begin{array}{l}1.74 \\
(0.42)\end{array}$ & $\begin{array}{l}1.55 \\
(0.43)\end{array}$ & $\begin{array}{l}1.64 \\
(0.38)\end{array}$ \\
\hline $\begin{array}{l}\text { share of } \\
\text { electric cars }\end{array}$ & $\begin{array}{l}0.03 \\
(0.01) \\
\end{array}$ & $\begin{array}{l}0.03 \\
(0.01) \\
\end{array}$ & $\begin{array}{l}0.03 \\
(0.01) \\
\end{array}$ & $\begin{array}{l}0.03 \\
(0)\end{array}$ & $\begin{array}{l}0.03 \\
(0)\end{array}$ & $\begin{array}{l}0.03 \\
(0) \\
\end{array}$ & $\begin{array}{l}0.03 \\
(0)\end{array}$ & $\begin{array}{l}0.03 \\
(0)\end{array}$ & $\begin{array}{l}0.03 \\
(0)\end{array}$ & $\begin{array}{l}0.04 \\
(0)\end{array}$ & $\begin{array}{l}0.04 \\
(0)\end{array}$ & $\begin{array}{l}0.04 \\
(0)\end{array}$ \\
\hline $\begin{array}{l}\text { emissions } \\
{[\text { mln tonnes }} \\
\text { of } \mathrm{CO} 2]\end{array}$ & $\begin{array}{l}41.11 \\
(1.91) \\
\end{array}$ & $\begin{array}{l}36.9 \\
(2.07) \\
\end{array}$ & $\begin{array}{l}37.27 \\
(2.03) \\
\end{array}$ & $\begin{array}{l}44.02 \\
(1.85) \\
\end{array}$ & $\begin{array}{l}40.43 \\
(1.54) \\
\end{array}$ & $\begin{array}{l}40.03 \\
(1.93) \\
\end{array}$ & $\begin{array}{l}43.38 \\
(1.98) \\
\end{array}$ & $\begin{array}{l}39.91 \\
(1.29) \\
\end{array}$ & $\begin{array}{l}39.41 \\
(1.58) \\
\end{array}$ & $\begin{array}{l}47.59 \\
(2.21)\end{array}$ & $\begin{array}{l}43.37 \\
(1.48)\end{array}$ & $\begin{array}{l}43.15 \\
(1.78)\end{array}$ \\
\hline $\begin{array}{l}\text { mean FC of } \\
\text { petrol cars }\end{array}$ & $\begin{array}{l}4.48 \\
(0.01) \\
\end{array}$ & $\begin{array}{l}4.48 \\
(0.01) \\
\end{array}$ & $\begin{array}{l}4.48 \\
(0.01) \\
\end{array}$ & $\begin{array}{l}4.85 \\
(0.08) \\
\end{array}$ & $\begin{array}{l}4.86 \\
(0.08) \\
\end{array}$ & $\begin{array}{l}4.86 \\
(0.08) \\
\end{array}$ & $\begin{array}{l}4.79 \\
(0)\end{array}$ & $\begin{array}{l}4.79 \\
(0)\end{array}$ & $\begin{array}{l}4.79 \\
(0)\end{array}$ & $\begin{array}{l}5.31 \\
(0)\end{array}$ & $\begin{array}{l}5.31 \\
(0)\end{array}$ & $\begin{array}{l}5.31 \\
(0)\end{array}$ \\
\hline $\begin{array}{l}\text { mean FC of } \\
\text { diesel cars }\end{array}$ & $\begin{array}{l}3.22 \\
(0.01) \\
\end{array}$ & $\begin{array}{l}3.22 \\
(0.01) \\
\end{array}$ & $\begin{array}{l}3.22 \\
(0.01) \\
\end{array}$ & $\begin{array}{l}3.4 \\
(0.04) \\
\end{array}$ & $\begin{array}{l}3.4 \\
(0.03) \\
\end{array}$ & $\begin{array}{l}3.39 \\
(0.04) \\
\end{array}$ & $\begin{array}{l}3.35 \\
(0)\end{array}$ & $\begin{array}{l}3.35 \\
(0)\end{array}$ & $\begin{array}{l}3.35 \\
(0)\end{array}$ & $\begin{array}{l}3.63 \\
(0)\end{array}$ & $\begin{array}{l}3.63 \\
(0)\end{array}$ & $\begin{array}{l}3.63 \\
(0)\end{array}$ \\
\hline $\begin{array}{l}\text { mean annual } \\
\text { distance by } \\
\text { petrol cars }\end{array}$ & $\begin{array}{l}15055 \\
(781)\end{array}$ & $\begin{array}{l}13278 \\
(592)\end{array}$ & $\begin{array}{l}13477 \\
(707)\end{array}$ & $\begin{array}{l}14841 \\
(846)\end{array}$ & $\begin{array}{l}13541 \\
(654)\end{array}$ & $\begin{array}{l}13311 \\
(812)\end{array}$ & $\begin{array}{l}14904 \\
(1030)\end{array}$ & $\begin{array}{l}13505 \\
(523)\end{array}$ & $\begin{array}{l}13381 \\
(811)\end{array}$ & $\begin{array}{l}14961 \\
(1035)\end{array}$ & $\begin{array}{l}13515 \\
(734)\end{array}$ & $\begin{array}{l}13381 \\
(815)\end{array}$ \\
\hline $\begin{array}{l}\text { mean annual } \\
\text { distance by } \\
\text { diesel cars }\end{array}$ & $\begin{array}{l}14743 \\
(983)\end{array}$ & $\begin{array}{l}13473 \\
(580)\end{array}$ & $\begin{array}{l}13432 \\
(912)\end{array}$ & $\begin{array}{l}14607 \\
(783)\end{array}$ & $\begin{array}{l}13449 \\
(644)\end{array}$ & $\begin{array}{l}13396 \\
(872)\end{array}$ & $\begin{array}{l}14566 \\
(722)\end{array}$ & $\begin{array}{l}13530 \\
(633)\end{array}$ & $\begin{array}{l}13341 \\
(799)\end{array}$ & $\begin{array}{l}14794 \\
(909)\end{array}$ & $\begin{array}{l}13548 \\
(634)\end{array}$ & $\begin{array}{l}13549 \\
(869)\end{array}$ \\
\hline Subsidy & $\begin{array}{l}5000 \\
(0)\end{array}$ & $\begin{array}{l}5000 \\
(0)\end{array}$ & $\begin{array}{l}5000 \\
(0)\end{array}$ & $\begin{array}{l}5000 \\
(0)\end{array}$ & $\begin{array}{l}5000 \\
(0)\end{array}$ & $\begin{array}{l}5000 \\
(0)\end{array}$ & $\begin{array}{l}5000 \\
(0)\end{array}$ & $\begin{array}{l}5000 \\
(0)\end{array}$ & $\begin{array}{l}5000 \\
(0)\end{array}$ & $\begin{array}{l}5000 \\
(0)\end{array}$ & $\begin{array}{l}5000 \\
(0)\end{array}$ & $\begin{array}{l}5000 \\
(0)\end{array}$ \\
\hline $\begin{array}{l}\text { Annual cost } \\
\text { of subsidy } \\
\text { [million] }\end{array}$ & $\begin{array}{l}313.22 \\
(154)\end{array}$ & $\begin{array}{l}375.67 \\
(211)\end{array}$ & $\begin{array}{l}361.09 \\
(190)\end{array}$ & $\begin{array}{l}476.44 \\
(63)\end{array}$ & $\begin{array}{l}447.06 \\
(77)\end{array}$ & $\begin{array}{l}460.32 \\
(75)\end{array}$ & $\begin{array}{l}459.08 \\
(57.7)\end{array}$ & $\begin{array}{l}450.28 \\
(60.2)\end{array}$ & $\begin{array}{l}452.47 \\
(60.2)\end{array}$ & $\begin{array}{l}659.54 \\
(17.7)\end{array}$ & $\begin{array}{l}661.43 \\
(18.2)\end{array}$ & $\begin{array}{l}659.15 \\
(17.2)\end{array}$ \\
\hline
\end{tabular}




\section{Appendix $\mathrm{C}$. The cost of financing the transition to a low-carbon economy}

The electrification of transport is considered as a viable option to mitigate impacts of climate change. The benefits can be only realized if the deployment of electric cars is combined with the diffusion of renewable energy in the electricity sector. Such intertwined transitions create a challenge for the grid integration, a discussion which is beyond the scope of this paper (Eising et al. 2014). Instead, we consider the impact of a rapid diffusion of renewable energy on the price of electricity and the rate of adoption of electric vehicles. So far, the impact of diffusion of renewable energy on the electricity price has been a source of the controversy. In general, it is expected that adding renewable energy technologies, characterized by a low marginal cost, to electricity production will lower the price of electricity in the short-run (Jensen and Skytte, 2002). But in the long-run, increasing investments in renewable installed capacities is often financed by increasing the final electricity price paid to consumers (Moreno et al., 2012). Our model captures these two opposing effects: in the short run, increasing the share of renewable energy lowers the electricity price, because more electricity is produced with technologies characterized by lower marginal costs. However, as a result of lower electricity prices, the newly installed power plants become smaller in size as the size of newly installed power plants is determined by their future expected profits given the current price of electricity. Less installed capacity translates into less electricity produced, and thus a higher electricity price.

In this context, the question arises how higher electricity prices would affect the rate of adoption of electric vehicles. We find that on average the cost of electricity in the 2050 energy scenario is three times higher compared to 2010 scenario (Figure $\mathrm{C} 1(\mathrm{a})$ ). This has been accompanied by the reduction of emissions from the electricity sector from $0.16 \mathrm{~kg}$ of $\mathrm{CO} 2$ per $\mathrm{kWh}$ to 0.05 because of increasing the share of renewable energy rapidly in electricity generation under the 2050 scenario (see Appendix B for the distribution of different energy sources in the electricity generation under different energy scenarios). Yet, this came at the price of quadrupling annual expenses in installed capacity of power plants between 2010 and 2050 scenarios (Figure C1(b)). 


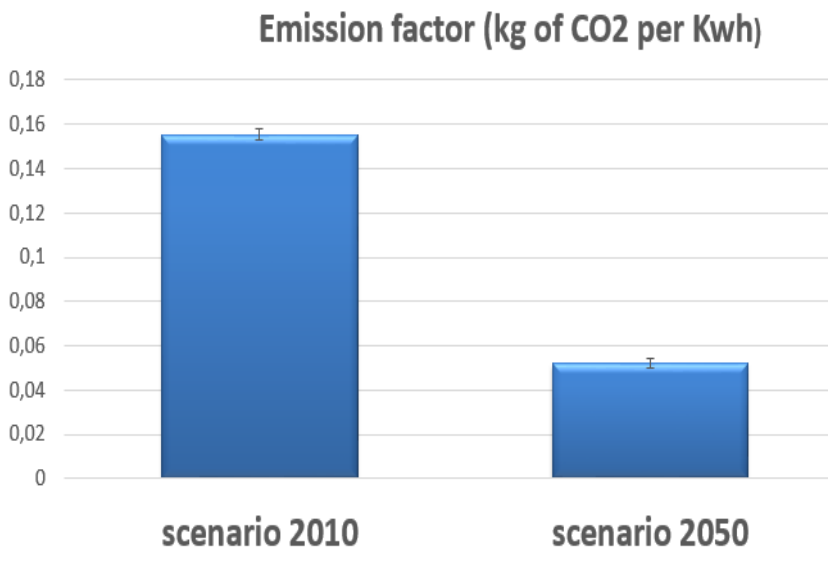

(a) Emission factors from electricity generation

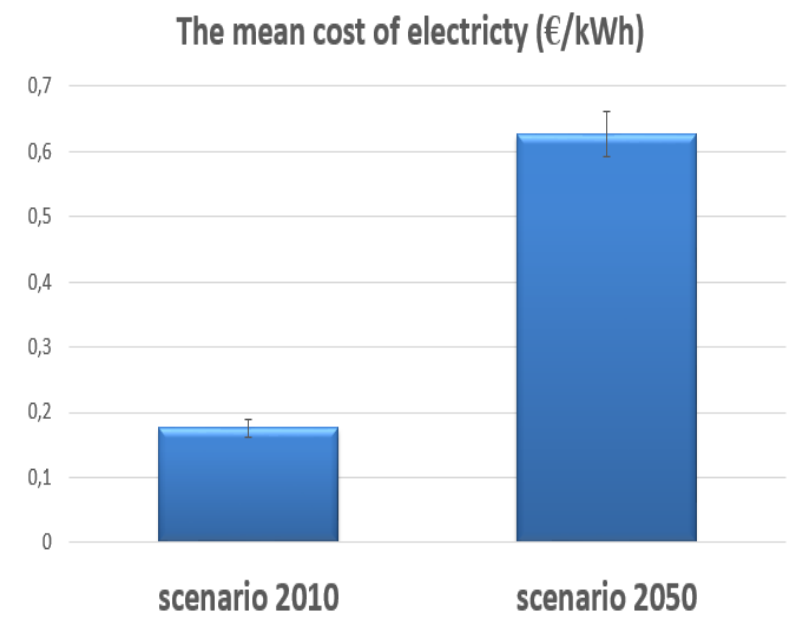

(b) The cost of electricity
Annual cost of investments in installed capacity [€ thousands]

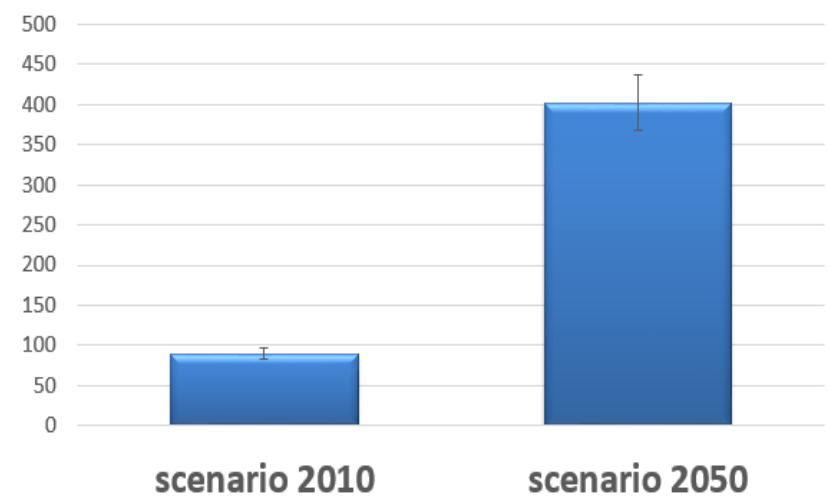

(b) Annual investments in electricity sector

Figure C1. The electricity market (mean values over 100 simulations) 